DOE/NV/10384-28

UC-703

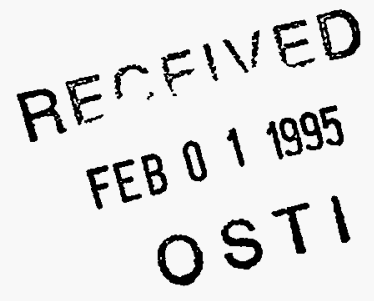

\title{
CLASSIFICATION OF GROUNDWATER AT THE NEVADA TEST SITE
}

by

Jenny B. Chapman

\section{AUGUST 1994}

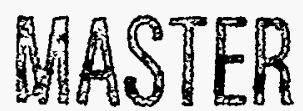

DISTRIBUTION OF THIS DOCUMENT IS UNLIMITED

Publication \#45069 


\section{DISCLAIMER}

This report was prepared as an account of work sponsored by an agency of the United States Government. Neither the United States Government nor any agency thereof, nor any of their employees, make any warranty, express or implied, or assumes any legal liability or responsibility for the accuracy, completeness, or usefulness of any information, apparatus, product, or process disclosed, or represents that its use would not infringe privately owned rights. Reference herein to any specific commercial product, process, or service by trade name, trademark, manufacturer, or otherwise does not necessarily constitute or imply its endorsement, recommendation, or favoring by the United States Government or any agency thereof. The views and opinions of authors expressed herein do not necessarily state or reflect those of the United States Government or any agency thereof. 


\section{DISCLAIMER}

Portions of this document may be illegible in electronic image products. Images are produced from the best available original document. 
This report was prepared as an account of work sponsored by the United States Government. Neither the United States nor the United States Department of Energy, nor any of their employees, makes any warranty, express or implied, or assumes any legal liability or responsibility for the accuracy, completeness or usefulness of any information, apparatus, product or process disclosed, or represents that its use would not infringe privately owned rights. Reference herein to any specific commercial product, process, or service by trade name, mark, manufacturer, or otherwise, does not necessarily constitute or imply its endorsement, recommendation, or favoring by the United States Government or any agency thereof. The views and opinions of authors expressed herein do not necessarily state or reflect those of the United States Government or any agency thereof.

This report has been reproduced directly from the best available copy.

Available to DOE and DOE contractors from the Office of Scientific and Technical Information, P.O. Box 62, Oak Ridge, TN 37831; prices available from (615) 576-8401.

Available to the public from the National Technical Information Service, U.S. Department of Commerce, 5285 Port Royal Rd., Springfield, VA 22161. 


\title{
CLASSIFICATION OF GROUNDWATER AT THE NEVADA TEST SITE
}

\author{
prepared by \\ Jenny B. Chapman \\ Water Resources Center \\ Desert Research Institute \\ University and Community College System of Nevada
}

Publication No. 45069

prepared for

Nevada Operations Office

U.S. Department of Energy

Las Vegas, Nevada

August 1994

The work upon which this report is based was supported by the U.S. Department of Energy under Contracts \#DE-AC08-85NV10384 and \#DE-AC08-90NV10845. 


\section{EXECUTIVE SUMMARY}

Groundwater occurring at the Nevada Test Site (NTS) has been classified according to the "Guidelines for Ground-Water Classification Under the U.S. Environmental Protection Agency (EPA) Ground-Water Protection Strategy" (June 1988). All of the groundwater units at the NTS are Class II, groundwater currently (IIA) or potentially (IIB) a source of drinking water.

The Classification Review Area (CRA) for the NTS is defined as the standard two-mile distance from the facility boundary recommended by EPA. The possibility of expanding the CRA was evaluated, but the two-mile distance encompasses the area expected to be impacted by contaminant transport during a 10-year period (EPA's suggested limit), should a release occur. The CRA is very large as a consequence of the large size of the NTS and the decision to classify the entire site, not individual areas of activity. Because most activities are located many miles hydraulically upgradient of the NTS boundary, the CRA generally provides much more than the usual two-mile buffer required by EPA. The CRA is considered sufficiently large to allow confident determination of the use and value of groundwater and identification of potentially affected users.

The size and complex hydrogeology of the NTS are inconsistent with the EPA guideline assumption of a high degree of hydrologic interconnection throughout the review area. To more realistically depict the site hydrogeology, the CRA is subdivided into eight groundwater units. Two main aquifer systems are recognized: the lower carbonate aquifer system and the Cenozoic aquifer system (consisting of aquifers in Quaternary valley fill and Tertiary volcanics). These aquifer systems are further divided geographically based on the location of low permeability boundaries.

None of the groundwater in the CRA qualified as Class I (special groundwater of unusually high value that is highly vulnerable to contamination and is an irreplaceable source of drinking water to a substantial population and/or ecologically vital). No ecologically vital areas are present in the CRA because no listed or proposed threatened or endangered species rely on the few groundwater discharge points. One endangered species, the desert tortoise, will consume spring water if available, but does not rely on surface water for survival. Though the Desert National Wildlife Range overlaps the eastern portion of the CRA, groundwater flows from the refuge toward the NTS. The EPA considers 500 people to be a substantial population, while only 45 to 65 people reside within the CRA in the part of Amargosa Valley formerly known as Lathrop Wells. As of April 1994, 2,799 people worked at the NTS, but the relationship between a worker population and the EPA guidelines is open to interpretation. Given the distribution of the workers in several hydrogeologic subdivisions, their non-resident status, and abundance of bottled water supplied from outside the CRA, the population relying on CRA groundwater is not considered substantial. Additional analysis determined that the groundwater is not highly vulnerable to contamination, primarily because of the great depth of groundwater below land surface and the low annual precipitation, and that it could be replaced by supplies within a 25 -mile pipeline distance.

The lower carbonate aquifer in the eastern and southern part of the CRA, the Cenozoic aquifer system in the southwestern part of the CRA, the Cenozoic aquifer system in Frenchman 
Flat, and the Cenozoic aquifer system on Pahute Mesa are all current sources of drinking water and have a Class IIA designation. Large areas within these subdivisions do not have production wells and are far removed from any well-capture zones. However, since no hydrologic barriers can be demonstrated within them, entire subdivisions must be classified as a "current source of drinking water."

The lower carbonate aquifer in the northeast and northwest parts of the CRA and the Cenozoic aquifer systems in Yucca Flat and Mercury Valley are classified as Class IIB, potential sources of drinking water. 


\section{CONTENTS}

EXECUTIVE SUMMARY $\ldots \ldots \ldots \ldots \ldots \ldots \ldots \ldots \ldots \ldots \ldots \ldots \ldots \ldots \ldots$ i

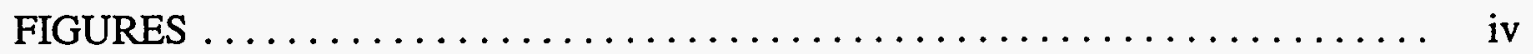

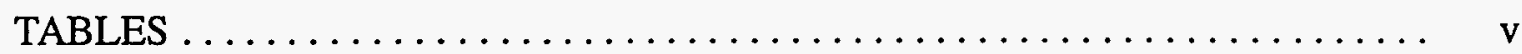

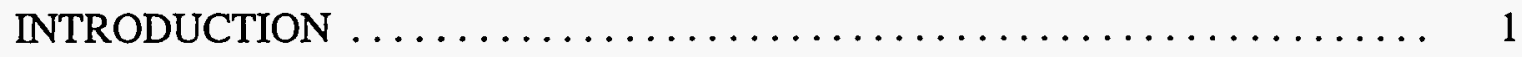

SUMMARY OF METHODS $\ldots \ldots \ldots \ldots \ldots \ldots \ldots \ldots \ldots \ldots \ldots \ldots \ldots \ldots \ldots \ldots$

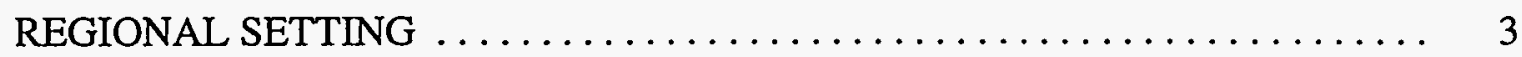

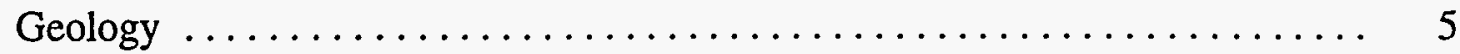

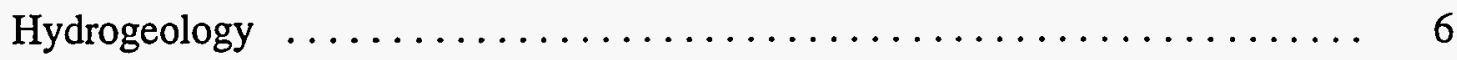

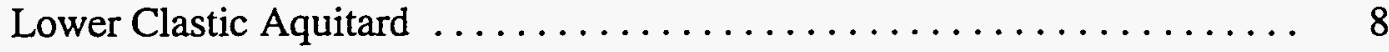

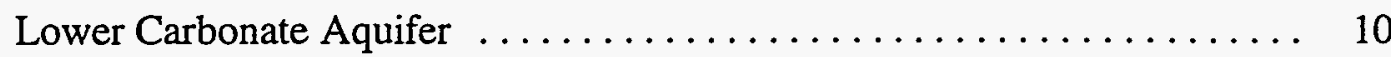

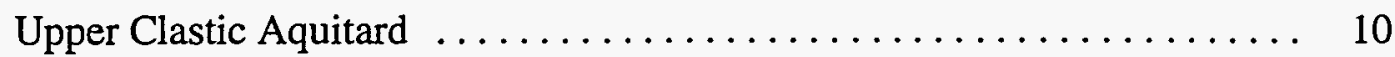

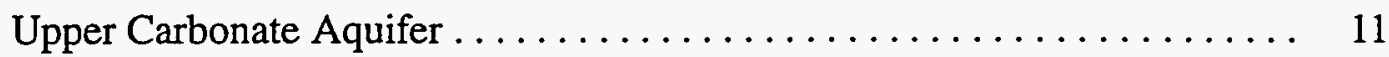

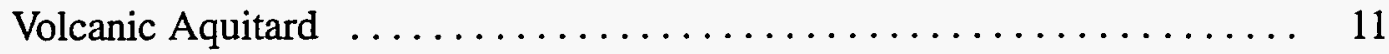

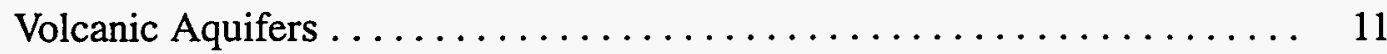

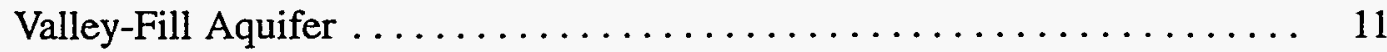

Regional Groundwater Movement ...................... 12

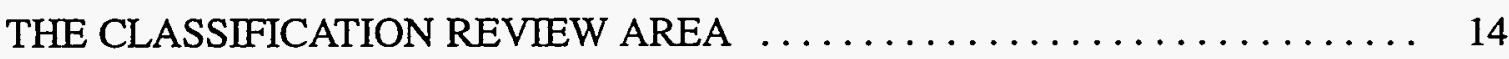

Expansion of the Classification Review Area $\ldots \ldots \ldots \ldots \ldots \ldots \ldots \ldots . \ldots \ldots$

Groundwater Flow Velocities at the Nevada Test Site ............ 15

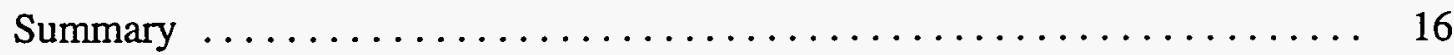

HYDROGEOLOGIC SUBDIVISIONS OF THE NTS CRA $\ldots \ldots \ldots \ldots \ldots \ldots .16$

Approach to Boundary Justification $\ldots \ldots \ldots \ldots \ldots \ldots \ldots \ldots \ldots \ldots \ldots \ldots \ldots$

Type 2 Boundary Between the Lower Clastic Aquitard

and the Lower Carbonate Aquifer ....................... 19

Type 2 Boundary in the Lower Carbonate Aquifer ............... 23

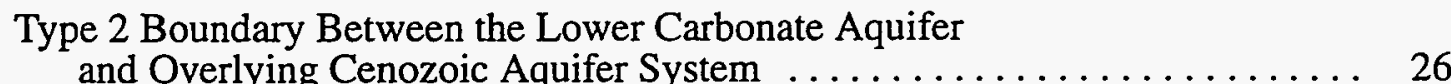

Type 2 Boundary Between the Cenozoic Aquifer System

in the East and West Sides of the CRA and From Valley to Valley ....... 29

EVALUATION OF CLASSIFICATION FACTORS . ............... 31

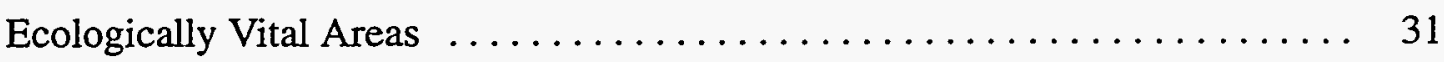

Groundwater Discharge Areas ....................... 31

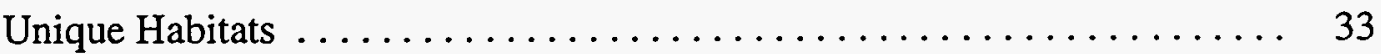

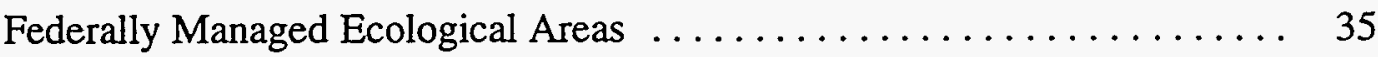

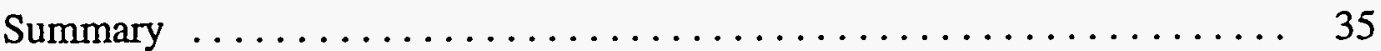

Drinking Water Wells in the Classification Review Area $\ldots \ldots \ldots \ldots \ldots \ldots . \ldots$

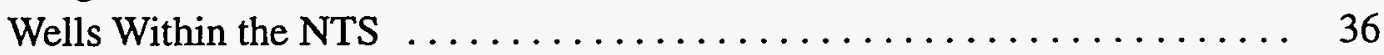

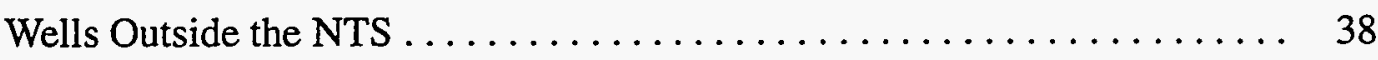




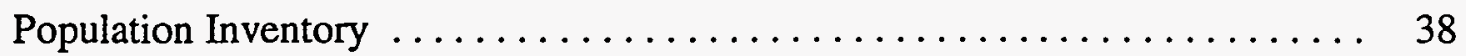

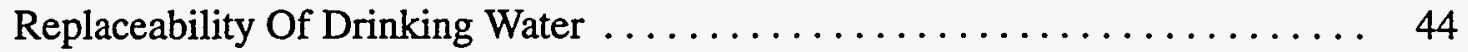

Screening Test 1: Uncommon Pipeline Distance ............. 44

Screening Test 2: Institutional Constraints $\ldots \ldots \ldots \ldots \ldots \ldots \ldots \ldots, 46$

Screening Test 3: Comparable Quality $\ldots \ldots \ldots \ldots \ldots \ldots \ldots \ldots, 46$

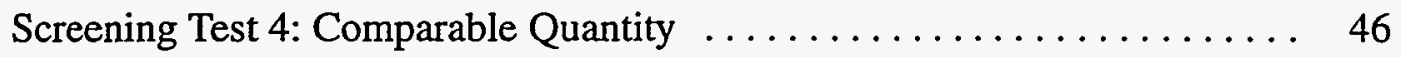

Screening Test 5: Economic Irreplaceability $\ldots \ldots \ldots \ldots \ldots \ldots \ldots \ldots$

Final Irreplaceability Determination $\ldots \ldots \ldots \ldots \ldots \ldots \ldots \ldots \ldots, 48$

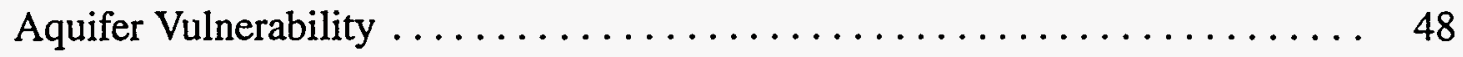

GROUNDWATER CLASSES AT THE NEVADA TEST SITE ........... 49

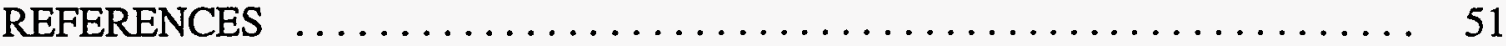

\section{FIGURES}

1. Location map for the Nevada Test Site $\ldots \ldots \ldots \ldots \ldots \ldots \ldots \ldots \ldots, 2$

2. Schematic chart of general classification procedures $\ldots \ldots \ldots \ldots \ldots \ldots, 4$

3. Location of three groundwater subbasins tentatively identified

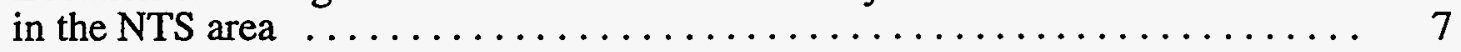

4. Regional geographic features discussed in the text $\ldots \ldots \ldots \ldots \ldots \ldots \ldots .8$

5. Major topographic features referred to in the hydrogeologic

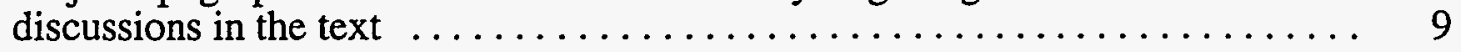

6. Groundwater table elevation in feet at the Nevada Test Site $\ldots \ldots \ldots \ldots \ldots, 12$

7. Approximate depth in feet to the water table below land surface at the Nevada Test Site .............................. 13

8. The Classification Review Area (CRA) for the Nevada Test Site . . . . . . . 17

9. Hydrogeologic subdivisions of the CRA with an idealized stratigraphic column $\ldots \ldots \ldots \ldots \ldots \ldots \ldots \ldots \ldots \ldots \ldots . \ldots \ldots$

10. Lower and upper clastic aquitards $\ldots \ldots \ldots \ldots \ldots \ldots \ldots \ldots \ldots \ldots .21$

11. Detail of hydrogeologic conditions in the northeastern part of the Nevada Test Site, near the outcrop of the lower clastic aquitard .......... 22

12. Hydraulic head values in the lower carbonate aquifer .............. 24

13. Hydraulic head values in the Cenozoic aquifer system $\ldots \ldots \ldots \ldots \ldots \ldots 26$

14. Hydraulic head values in the Cenozoic-age volcanic aquifer on Pahute Mesa . . 27

15. Location of boundary between the Ash Meadows groundwater subbasin and the Alkali Flat-Furnace Creek Ranch groundwater subbasin .......... 


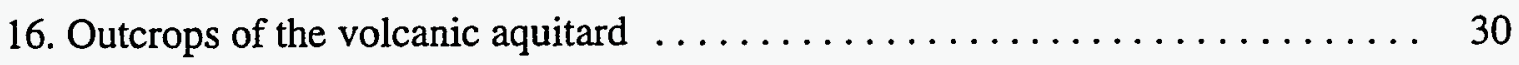

17. Location of some springs in the NTS CRA $\ldots \ldots \ldots \ldots \ldots \ldots \ldots \ldots .32$

18. Water wells and pipelines on the NTS. Wells UE15d, UE1r, UE5C, and Well $A$ are all out of service as of $1994 \ldots \ldots \ldots \ldots \ldots \ldots \ldots \ldots \ldots$

19. Water wells in the Lathrop Wells/Amargosa Valley area ............ 39

20. Demographic analysis for the area south and west of the NTS, identifying 37 people residing in census blocks intercepted by the CRA . . . . 40

21. Location of the census block including the NTS and Nellis Air Force Range . . 41

22. Map of southern Nevada showing the NTS, two-mile CRA boundary, and 25 -mile "uncommon pipeline distance" $\ldots \ldots \ldots \ldots \ldots \ldots \ldots \ldots, 45$

23. Hydrographic areas within 25 miles of the NTS boundary $\ldots \ldots \ldots \ldots \ldots 47$

24. Classification assigned to the hydrogeologic subdivisions of the NTS CRA ... 50

\section{TABLES}

1. Stratigraphic and Hydrologic Column for the Nevada Test Site and Vicinity ... 5

2. Range of Transmissivity and Specific Capacity of Aquifers and Aquitards .... 23

3. Endangered and Threatened and Candidate Species that May Occur on

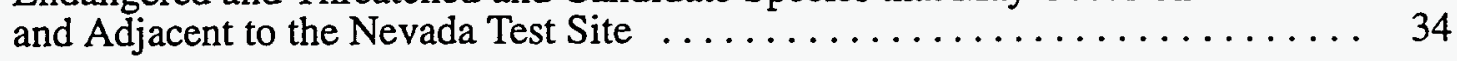

4. Water Supply Wells on the NTS $\ldots \ldots \ldots \ldots \ldots \ldots \ldots \ldots \ldots \ldots \ldots \ldots \ldots \ldots \ldots$

5. Water Supply Wells Located off the NTS but within the CRA $\ldots \ldots \ldots \ldots .38$

6. NTS Population Breakdown by Wells and Hydrogeologic Subdivisions . . . . 42

7. Well Production Figures in Millions of Gallons Per Year ............ 43

8. Numerical Ranking of Aquifers using the DRASTIC System to Determine Vulnerability of Aquifers to Surface Contaminants 


\section{INTRODUCTION}

In August 1984, the U.S. Environmental Protection Agency (EPA) issued its Ground-Water Protection Strategy (U.S. EPA, 1984) outlining a common reference for preserving clean groundwater for current and future use and for protecting the public's health from groundwater contamination. An important concept outlined in this strategy is that groundwater protection should consider the value and vulnerability of a groundwater unit when defining protection policies. Three general classes of groundwater were identified, and each is accorded a different level of protection. The classification is as follows:

I. Special groundwater,

II. Groundwater currently or potentially a source of drinking water,

III. Groundwater not a potential source of drinking water and of limited beneficial use.

Class I groundwaters are resources of unusually high value that are highly vulnerable to contamination and are irreplaceable sources of drinking water to substantial populations and/or ecologically vital. For the Class II waters, a current source is designated $\Pi \mathrm{A}$, while a potential source is IIB. The concept of "current source of drinking water" is intentionally broad so that only a portion of the groundwater needs to be supplying water to a well used for drinking water to result in a current use classification for the entire unit. To be considered a Class III groundwater (of limited beneficial use), the water must have a total dissolved solids content (TDS) over 10,000 milligrams per liter ( $\mathrm{mg} / \mathrm{L}$ ), have well yields insufficient to serve an average size family, or be contaminated by either naturally occurring conditions or broad-scale human activity (unrelated to a specific activity) such that it cannot reasonably be treated. If a Class III groundwater has a high to intermediate degree of connection to adjacent Class I or II groundwater units or surface water, the designation is IIIA. A low degree of interconnection with other waters leads to the lowest class designation, ImB.

Based on a preliminary analysis, the EPA believes that the vast majority of groundwaters in the U.S. will be classified as Class II. If a groundwater does not meet the Class I criteria, it will be assumed to be a Class II water unless demonstrated otherwise on the basis of quality and yield. If a Class III designation is proven, the groundwater is considered highly interconnected with other waters (a Class IIIA designation) unless proven otherwise. In other words, the burden of proof is on justifying a less restrictive classification. In ambiguous situations, or if data are lacking, the more restrictive classification applies.

The classification guidelines themselves are not enforceable requirements. However, the classification system can be applied through EPA programs and implemented in their statutes. The Superfund program uses the Ground-Water Protection Strategy (U.S. EPA, 1984) as guidance when determining appropriate remediation for contaminated groundwater at Comprehensive Environmental Response, Compensation and Liability Act (CERCLA) sites. EPA states that guidance for determining if a contaminated groundwater is Class I, II, or III can be found in the EPA Guidelines for Ground-Water Classification (Final Draft, December 1986). This classification is then used to decide the remediation goal for groundwater restoration, the timeframe within which 
restoration will occur, and the most appropriate method for achieving these goals (Federal Register, Vol. 55, No. 46, Thursday March 8, 1990, p. 8732).

This report describes the classification of groundwater at the Nevada Test Site (NTS), located in southern Nevada (Figure 1). The classification assigned to groundwater at the NTS will be a factor in decisions regarding levels of protection and remediation under EPA regulations. The classification was performed by the Desert Research Institute (DRI) at the request of the U.S. Department of Energy (DOE). DOE provided DRI with the 1988 classification guidelines. The Guidelines for Ground-Water Classification Under the EPA Ground-Water Protection Strategy (June 1988) describe the process of classification for groundwater potentially affected by a facility or activity. Unfortunately, EPA has apparently rejected the 1988 revision and refers instead to the 1986 Final Draft (Chuck Job, U.S. EPA, pers. comm. 9/26/94). DRI performed an earlier, unpublished classification according to the 1986 Final Draft and found no difference in the resulting classes assigned to NTS aquifers. The application of either set of guidelines to the NTS is not always

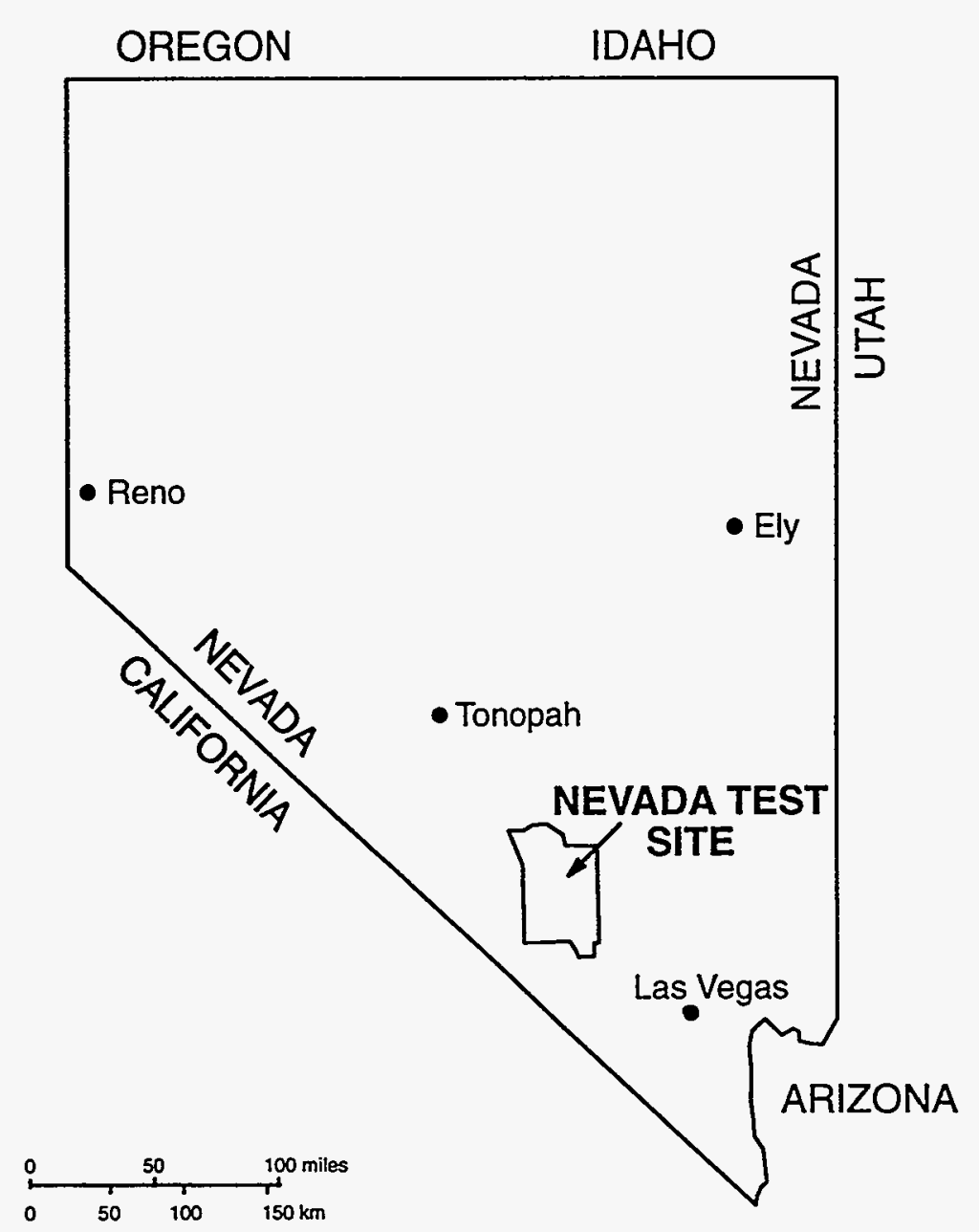

Figure 1. Location map for the Nevada Test Site. 
straightforward, primarily because of the size of the site and the non-resident (i.e., worker) status of most of the people drinking water in the area.

\section{SUMMARY OF METHODS}

The process followed in this report for the NTS generally parallels that suggested by the EPA (Figure 2). The first step is to identify the Classification Review Area (CRA) in which groundwater will be examined. In most cases, this simply involves drawing a circle with a two-mile radius around the facility. Certain hydrogeologic situations, however, may require expansion of the CRA, and those situations are evaluated for the NTS.

The EPA guidelines are written with relatively small sites (such as surface impoundments) in mind, so it is assumed that there is a high degree of hydrologic interconnection throughout the review area. The size and complex hydrogeology of the NTS are inconsistent with this assumption. The identification of hydrogeologic subdivisions allows for the recognition of groundwater units that have significantly different use and value. The NTS Classification Review Area is thus subdivided into hydrogeologic units, creating a realistic depiction of the site hydrology based on current knowledge.

Once the review area and hydrogeologic units have been defined, specific classification parameters are evaluated. The presence of endangered species and the hydrogeologic relationships between the NTS and the Desert National Wildlife Range and minor spring habitats in the area are evaluated to determine the role of ecologically vital areas in the classification. The location and use of all water supply wells in the CRA and populations served by the wells are tabulated and described. The replaceability of the groundwater supply is evaluated, as is the vulnerability of groundwater to contamination. Finally, a groundwater class is assigned to each of the hydrogeologic subdivisions of the aquifers in the CRA.

This report is organized following the sequence of work outlined above. After an introduction to the regional hydrogeologic setting, an evaluation of the Classification Review Area is presented. Subdivision of the CRA into hydrogeologic units is then described and justified. Ecologically vital areas, drinking water supplies, population patterns, water-supply replaceability, and groundwater vulnerability are evaluated according to the guidelines. The classification criteria are then reviewed for each unit and a class assigned. Measurements are written as English units herein to be consistent with those used in the EPA guidelines.

\section{REGIONAL SETTING}

This section provides a description of the geology and hydrogeology of the NTS. This description is as general as the complexity of the site geology will allow. Detailed analysis of the interconnection and divisions between hydrogeologic units is presented in a later section. The primary source of information on the hydrogeology of the NTS and surrounding areas is Winograd and Thordarson (1975). The following discussion is derived primarily from that source. 


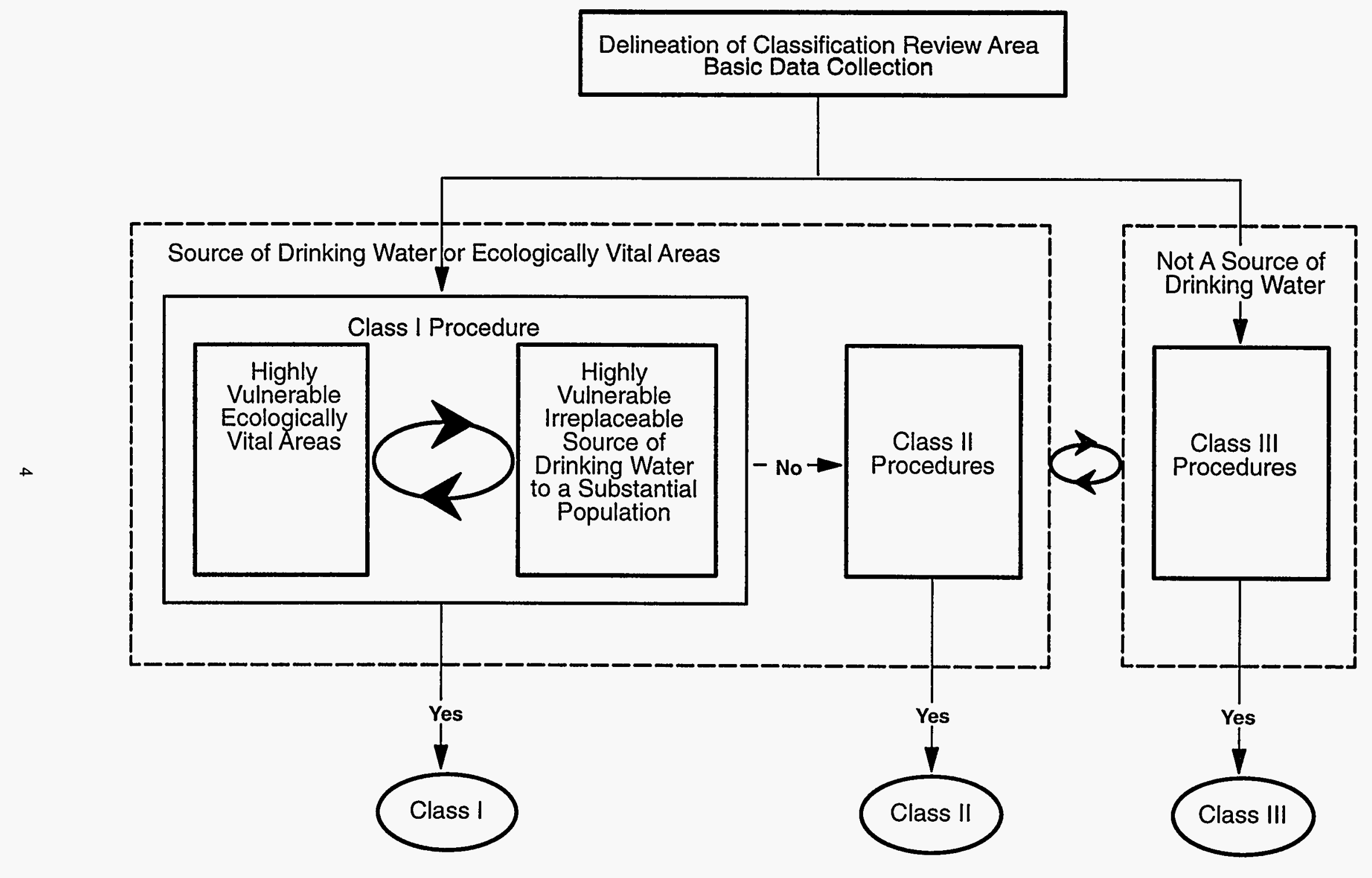

Figure 2. Schematic chart of general classification procedures (from EPA, 1988). 


\section{Geology}

The NTS is located in the miogeosynclinal belt of the Cordilleran geosyncline, in which 37,000 feet ( $\mathrm{ft}$ ) of marine sediments accumulated during the Precambrian and Paleozoic eras. These rocks consist of, in ascending order, thick sequences of quartzite and siltstone, limestone and dolomite, argillite and quartzite, and limestone (Table 1). Rocks of Mesozoic age are limited to a few minor intrusive granitic stocks. The Cenozoic marks another major depositional period as the region is located in a Tertiary volcanic province. Both pyroclastic and lava-flow type volcanics, locally more than $13,000 \mathrm{ft}$ thick, were erupted from large caldera centers in the area. Quaternary alluvial deposits and minor basalt flows are generally less than $2,000 \mathrm{ft}$ thick.

TABLE 1. Stratigraphic and Hydrologic Column for the Nevada Test Site and Vicinity.*

\begin{tabular}{|c|c|c|c|}
\hline System/Series & Stratigraphic Unit/Lithology & \multicolumn{2}{|c|}{ Hydrogeologic Unit } \\
\hline $\begin{array}{l}\text { Quaternary and Tertiary } \\
\text { (Pliocene, Pleistocene, } \\
\text { Holocene) }\end{array}$ & $\begin{array}{l}\text { Alluvial, fluvial, fanglomerate, lakebed and } \\
\text { mudflow deposits }\end{array}$ & Valley-fill aquifer & $\begin{array}{l}\text { Cenozo } \\
\text { aquifer }\end{array}$ \\
\hline $\begin{array}{l}\text { Tertiary (Miocene to } \\
\text { Pliocene) }\end{array}$ & $\begin{array}{l}\text { Welded and bedded tuffs and lava flows } \\
\text { between and including the Paintbrush Tuff and } \\
\text { Kiwi Mesa Basalt }\end{array}$ & Volcanic aquifer & \\
\hline $\begin{array}{l}\text { Tertiary (Oligocene to } \\
\text { Miocene) }\end{array}$ & $\begin{array}{l}\text { Tuffs and lava flows between and including } \\
\text { the Horse Spring Formation and Wahmonie } \\
\text { Formation }\end{array}$ & \multicolumn{2}{|l|}{ Volcanic aquitard } \\
\hline Cretaceous to Permian & Granitic stocks & \multicolumn{2}{|l|}{ Minor aquitard } \\
\hline $\begin{array}{l}\text { Permian and } \\
\text { Pennsylvanian }\end{array}$ & Tippipah Limestone & \multicolumn{2}{|c|}{ Upper carbonate aquifer } \\
\hline $\begin{array}{l}\text { Mississippian and } \\
\text { Devonian }\end{array}$ & Eleana Formation, argillite, quartzite & \multicolumn{2}{|c|}{ Upper clastic aquitard } \\
\hline Cambrian to Devonian & $\begin{array}{l}\text { Various limestone and dolomite formations, } \\
\text { notably the Devils Gate, Pogonip Group, } \\
\text { Nopah, Bonanza King and Carrara }\end{array}$ & \multicolumn{2}{|c|}{ Lower carbonate aquifer } \\
\hline Precambrian to Cambrian & $\begin{array}{l}\text { Quartzite and fine-grained clastics such as the } \\
\text { Stirling Quartzite and Johnnie Formation }\end{array}$ & \multicolumn{2}{|c|}{ Lower clastic aquitard } \\
\hline
\end{tabular}

Two major periods of deformation have disturbed the stratigraphic sequence. During the late Mesozoic, folding and thrust faulting occurred in the area as a result of plate convergence along the active western continental margin of North America (U.S. Geological Survey, 1984). This activity redistributed some of the Proterozoic and Paleozoic rocks into patterns that control the present flow paths in deep groundwater systems. The second major period of deformation occurred during the 
late Cenozoic and consisted of extensional tectonism and basin-and-range faulting, both of which may be the result of the change in the plate tectonic configuration of the western continental margin away from convergence and subduction and toward a strike-slip transform fault configuration. Resultant block faulting had a profound effect on the site hydrology by causing the juxtaposition of hydrogeologic units of differing transmissivities and creation of the characteristic basin-and-range topography with alluvium-filled valleys. Strike-slip faults in the area, such as the Las Vegas Shear Zone, are also believed to control regional groundwater flow (Winograd and Thordarson, 1975).

The basin-and-range topography at the NTS is typical of that found in the Great Basin physiographic province. The Great Basin is characterized by linear, fault-bounded ranges separated by valleys filled with alluvial sediment eroded from the adjacent highlands. Surface drainage is internal within the Great Basin with no through-flowing rivers. The highest range on the NTS is the Belted Range, varying in elevation from 5,000 to 7,000 ft. The elevations of the valley floors range from 3,000 to 4,500 ft. Many valleys contain playas at their lowest point. Slopes on the range edges are steep and dissected, while closer to the basins they are gentler due to alluviation with rock debris from adjacent highlands.

\section{Hydrogeology}

The NTS and surrounding areas are located within the Death Valley Groundwater Basin (Waddell et al., 1984). The Death Valley Groundwater Basin is internally draining with no known outlet to an ocean. Three groundwater subbasins have been suggested for the NTS on the basis of discharge areas upgradient of Death Valley, but some underflow to the springs in Death Valley is indicated by hydrologic and hydrochemical evidence (Winograd and Thordarson, 1975). The boundaries for the groundwater subbasins are ill-defined and subject to interpretation.

The eastern part of the NTS is in the Ash Meadows groundwater subbasin (Figure 3). A major portion of the discharge for the Ash Meadows groundwater subbasin occurs by evapotranspiration along a spring line in Ash Meadows (Figure 4). Subsequent infiltration of some spring water and some underflow probably moves downgradient from the Ash Meadows springs and joins the Alkali Flat-Furnace Creek Ranch groundwater subbasin. The Alkali Flat-Furnace Creek Ranch groundwater subbasin includes most of the western NTS. Discharge from this subbasin probably occurs by evapotranspiration at Alkali Flat and spring discharge near Furnace Creek Ranch. The Oasis Valley groundwater subbasin is the least well-defined and includes groundwater beneath the far northwestern corner of the NTS. Discharge may occur by evapotranspiration at Oasis Valley (west of the NTS), with some underflow joining the Alkali Flat-Furnace Creek Ranch groundwater subbasin.

Recharge for all the subbasins may occur by precipitation at the higher elevations and infiltration along streamcourses and in playas. Eakin et al. (1951) devised a method for estimating recharge to basins in Nevada based on the amount of precipitation received. For areas receiving less than eight inches of precipitation a year, they believe that no significant groundwater recharge occurs, while recharge of three percent of the precipitation is expected for annual precipitation of 


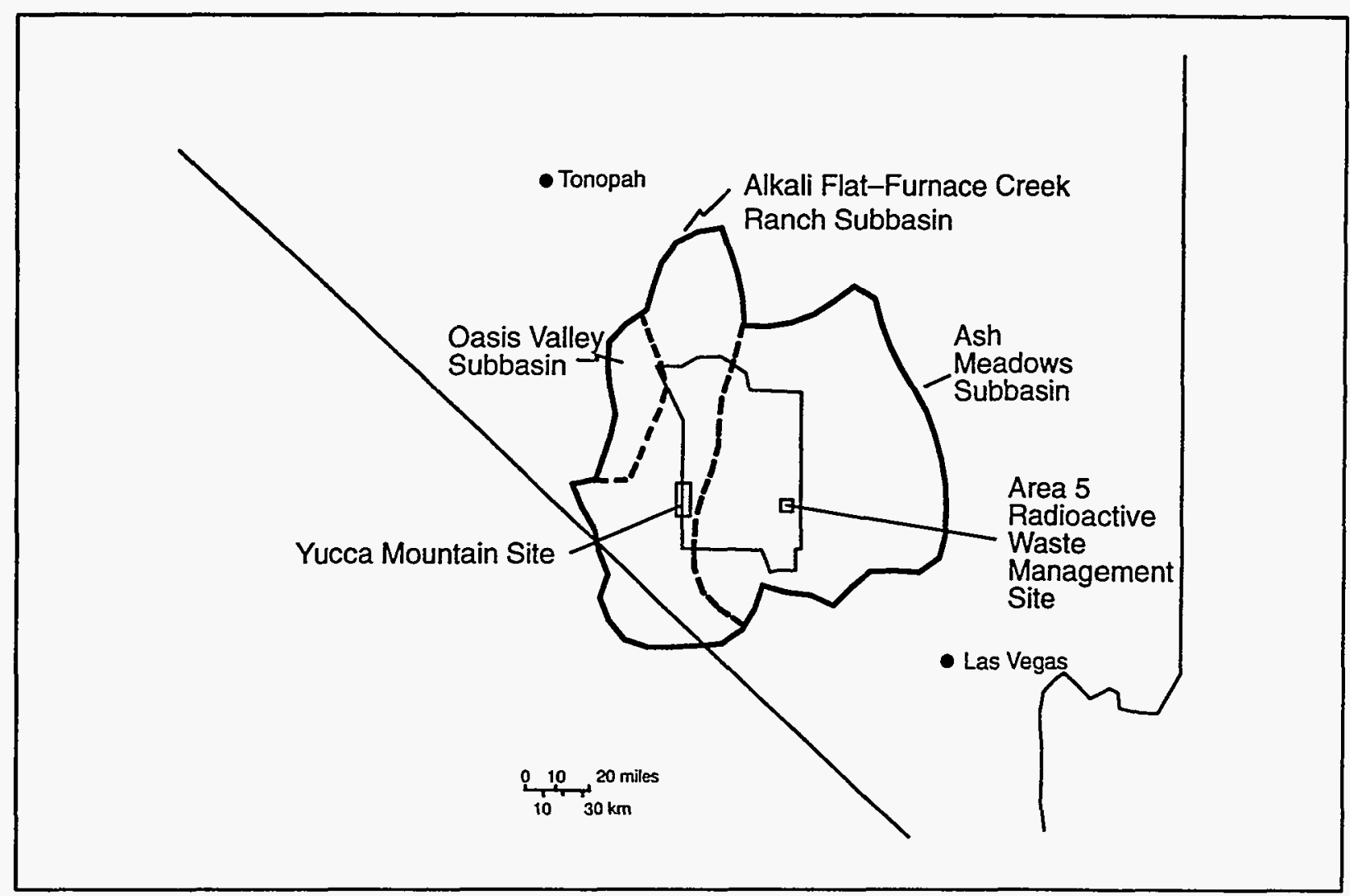

Figure 3. Location of three groundwater subbasins tentatively identified in the NTS area (from Winograd and Thordarson (1975) and Waddell et al. (1984)).

eight to 12 inches. Most of the NTS receives less than eight inches per year, with higher amounts falling on the small upland area around Shoshone Mountain and the Pahute Mesa region. Recent studies characterizing the hydrogeology of the unsaturated zone in Frenchman Flat near the Radioactive Waste Management Site (RWMS) have confirmed the absence of recharge at lower elevations. Hydraulic measurements on cores collected from three wells and 10 boreholes around the site indicate that water movement is upward toward the soil surface driven by the high evapotranspiration rate, rather than downward as groundwater recharge (Reynolds Electrical and Engineering Co., 1994). Chloride accumulations indicate that precipitation only infiltrates to seven feet at most before being lost to evapotranspiration. Differences between the stable isotopic composition of precipitation and that of soil water indicate that soil water below the top few feet was recharged under different climatic conditions than exist today (Tyler et al., in press). Using chloride mass balance techniques, Tyler et al. (1994) estimate that recharge to the water table at the RWMS has not occurred since the last glacial period 15,000 to 20,000 years ago, and even then, recharge only occurred in areas conducive to infiltration (such as along drainageways). The actual amount of recharge in the areas where current recharge is believed to occur on the NTS, such as on Pahute Mesa and along Fortymile Wash east of Yucca Mountain, is the subject of active research. However, the great depth to water throughout the NTS suggests that travel times for infiltration from the surface to the water table are long. 


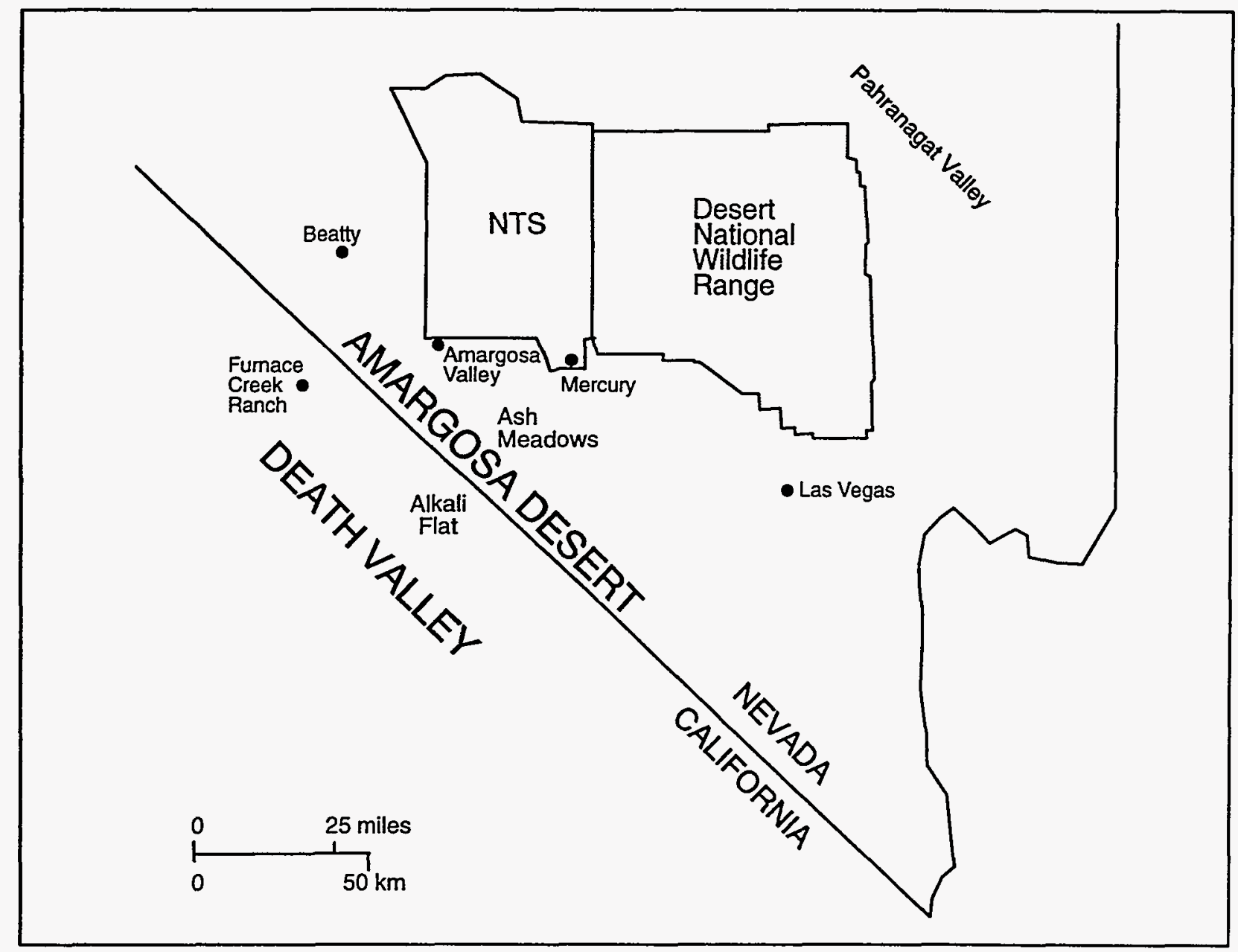

Figure 4. Regional geographic features discussed in the text.

Winograd and Thordarson (1975) recognize 10 hydrogeologic units in the NTS area. This discussion generally follows their designations, though volcanic aquitards are grouped together and the volcanic aquifers are discussed together where Winograd and Thordarson broke out several units (Table 1). The units will be briefly described, proceeding from stratigraphically oldest to youngest.

\section{Lower Clastic Aquitard}

This unit is the hydraulic basement for groundwater movement in the region. It contains Precambrian- to Early Cambrian-age siltstone, quartzite, shale, and sandstone. Limited test data from cores suggest a range in permeability of $7 \times 10^{-7}$ to $1 \times 10^{-6}$ gallons per day per square foot $\left(\mathrm{gpd} / \mathrm{ft}^{2}\right)$. The absence of moderate to high-yielding springs in strata of the lower clastic aquitard is also cited by Winograd and Thordarson (1975) as evidence of the lack of regionally integrated transmissivity in the clastic units. The lower clastic aquitard crops out only in the far northeast corner of the NTS, along the Halfpint Range (Figure 5). Just south of the NTS, the aquitard is also at or near the surface, causing a constriction of the area available for flow in the lower carbonate aquifer 


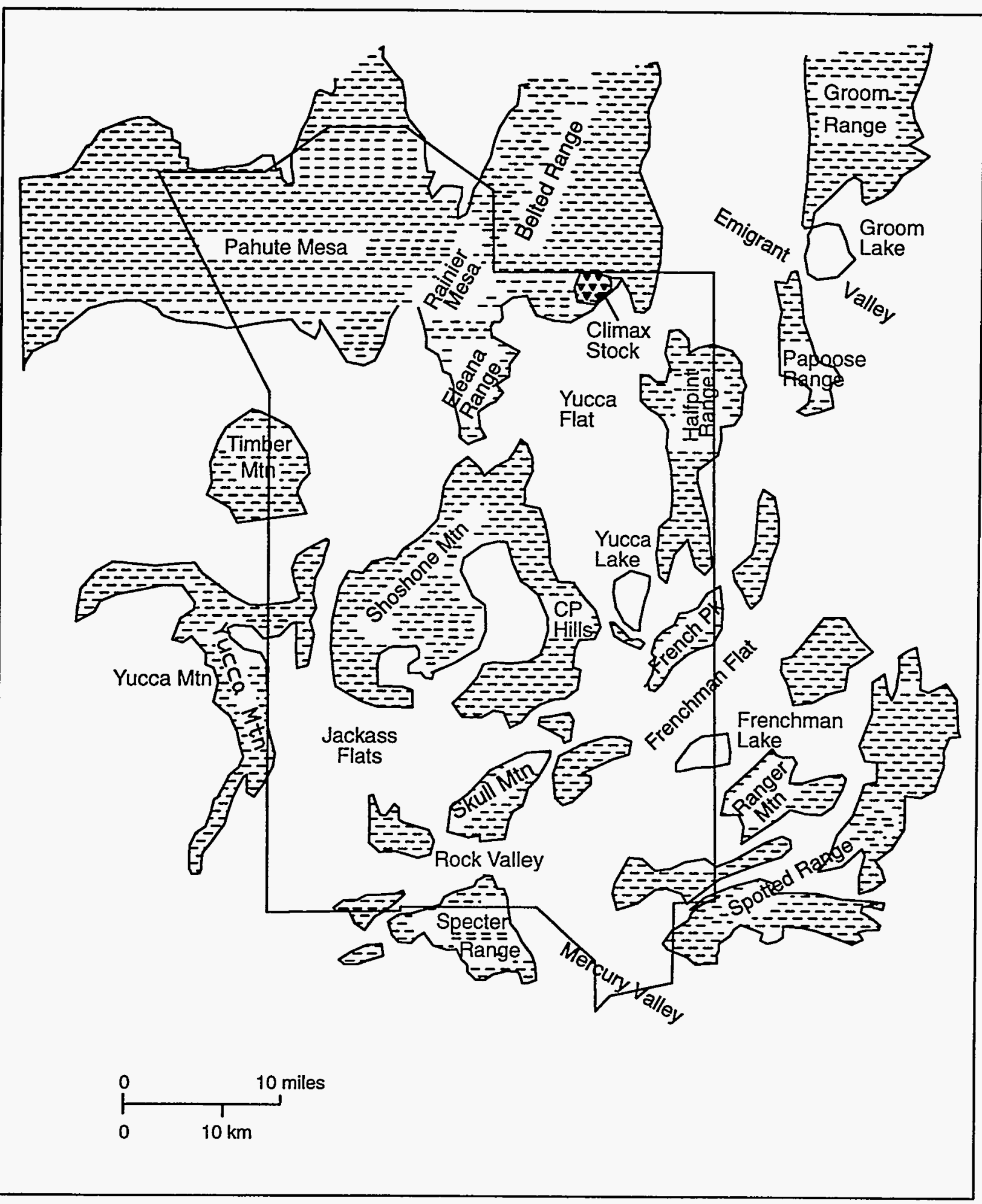

Figure 5. Major topographic features referred to in the hydrogeologic discussions in the text. Compiled from Winograd and Thordarson (1975), Maldonado (1985), and Barnes et al. (1963). 
near the Specter Range. Across much of the region, however, the lower clastic aquitard occurs thousands of feet below the surface.

\section{Lower Carbonate Aquifer}

The lower carbonate aquifer contains limestone and dolomite of Middle Cambrian through Devonian age and is one of the principal aquifers in the region. Generally, several thousand feet of the aquifer occur within the zone of saturation. The intercrystalline porosity of the carbonates is very low, but the rocks are highly fractured, locally brecciated, and locally contain solution-enlarged openings. The transmission of water in the lower carbonate aquifer is primarily through secondary openings developed along fractures. The transmissivity of the aquifer ranges from 600 to 900,000 $\mathrm{gpd} / \mathrm{ft}$, based on pumping-test analysis (Winograd and Thordarson, 1975). The regional importance of the lower carbonate aquifer is a result of both its high transmissivity and large areal extent. The carbonates are unsaturated or absent only near outcrops or buried structural highs of the lower clastic aquitard. The interbasin flow of groundwater in southern and eastern Nevada occurs through the lower carbonate aquifer (Maxey and Mifflin, 1966; Eakin, 1966). This interbasin movement is not significantly influenced by topographic boundaries, and integrates individual intermontane valleys into a single, large groundwater basin. Other aquifers at the NTS are limited in areal extent and/or continuity by intervening topographic highs and structural features. Though hydraulic barriers in the form of faults or juxtaposition against aquitards exist in the lower carbonate aquifer at the NTS, no major regional barriers have been identified. Thus, the lower carbonate aquifer is the only unit in the area that may be hydraulically connecting the entire NTS. In addition, throughout much of the area, the carbonates act as a sink for flow from overlying units. Though vertical leakage is estimated to be relatively slow, the lower carbonate aquifer provides a conduit for interbasin flow of groundwater originating in the tuff and alluvial aquifers as well.

Groundwater in the lower carbonate aquifer occurs under both confined and unconfined conditions. Water levels in the aquifer at the NTS are generally at least $1,000 \mathrm{ft}$ below land surface. Recharge to the aquifer may occur by precipitation on ridges and mountains composed of fractured carbonates and by infiltration through streamcourses. Underflow from upgradient basins also contributes water to the lower carbonate aquifer at the NTS. The majority of the underflow is probably from Pahranagat Valley, to the northeast. In addition, leakage from overlying aquifers contributes water to the lower carbonate aquifer in some areas of the NTS. Hydraulic heads decrease with depth in Yucca Flat (Winograd and Thordarson, 1975), providing a driving force for leakage across intervening aquitards in that basin. Much of the discharge for the lower carbonate aquifer in the Ash Meadows groundwater basin probably occurs at springs in Ash Meadows. Flow in the western part of the NTS moves toward Oasis Valley where some of it discharges by evapotranspiration and springflow near Beatty (Figure 4). Some underflow continues downgradient to the Amargosa Desert. An unknown quantity of the flow from throughout the NTS may continue downgradient to ultimately discharge in Death Valley.

\section{Upper Clastic Aquitard}

The upper clastic aquitard is formed by the Devonian- to Mississippian-age Eleana Formation. The formation contains up to $8,000 \mathrm{ft}$ of predominantly argillite with lesser amounts of quartzite and 
conglomerate. The transmissivity is believed to be less than $500 \mathrm{gpd} / \mathrm{ft}$, though data are lacking. The upper clastic aquitard is an important hydrologic feature running north-south along the center of the NTS where the upper and lower carbonate aquifers are hydraulically separated by thousands of feet of the upper clastic aquitard. East and west of this area, the Eleana has either been removed by erosion, occurs above the water table, or is represented by an equivalent carbonate facies.

\section{Upper Carbonate Aquifer}

The upper carbonate aquifer occurs in the Pennsylvanian- and Permian-age Tippipah Limestone. The aquifer is saturated only beneath the western part of Yucca Flat. It is separated from the lower carbonate aquifer in the Yucca Flat area by the upper clastic aquitard. With its limited areal extent, the upper carbonate aquifer does not play a major role in the regional movement of groundwater. The aquifer does, however, supply one of the NTS's water wells.

\section{Volcanic Aquitard}

The lower portion of the thick sequence of Tertiary volcanics (stratigraphically below the Paintbrush Tuff) contains tuffs and lava flows of relatively low transmissivity, designated by Winograd and Thordarson (1975) as aquitards. Fracture transmissivities are generally less than 500 $\mathrm{gpd} / \mathrm{ft}$ (Winograd and Thordarson, 1975). The aquitard is commonly thousands of feet thick. The volcanics are characterized by low interstitial permeability and poorly connected water-bearing fractures and can be fully saturated to unsaturated, depending on the local topography and structure. Perched groundwater occurs in the aquitard in several areas (notably at Rainier Mesa) and most of the small, perched springs at the NTS issue from the volcanic aquitard. In the Yucca Mountain area (southwest NTS), the volcanic aquitard contains the water table. The aquitard separates the overlying aquifers from the lower carbonate aquifer.

\section{Volcanic Aquifers}

Winograd and Thordarson (1975) identify three separate aquifers in the tuffs and lava flows of upper Miocene and Pliocene age, which are grouped together here with the valley-fill aquifer into the Cenozoic aquifer system. Water is transmitted in these units primarily through fractures and joints. Water-bearing fractures are thought to be restricted to zones of partial to dense welding. Generally, interstitial porosity and interstitial permeability vary inversely with the degree of welding, while fracture density is directly related to welding. The most transmissive unit is the welded-tuff aquifer, with measured transmissivities up to $100,000 \mathrm{gpd} / \mathrm{ft}$ in Jackass Flats (Winograd and Thordarson, 1975). The volcanics in the eastern part of the NTS are generally saturated only in the deeper parts of the intermontane basins. Across Pahute Mesa and the western part of the NTS, however, the volcanics are widely saturated and contain the water table.

\section{Valley-Fill Aquifer}

The valley-fill aquifer is one of the major aquifers in the southern Great Basin, supplying water in the Las Vegas Valley and in the Amargosa Desert. At the NTS, the valley-fill is an important aquifer only in the larger valleys. Across much of the site, the valley-fill is either absent or unsaturated. The valley-fill generally contains non-indurated alluvial fan, fluvial, fanglomerate, 
lakebed, and mudflow deposits and transmits water through interstitial openings. Transmissivities of between 800 and $34,000 \mathrm{gpd} / \mathrm{ft}$ have been measured during pumping tests (Winograd and Thordarson, 1975). This range is due in part to the different saturated thicknesses in the six wells tested. The valley-fill aquifer constitutes a major water source in Frenchman Flat. The great depth to the water table (approximately 700 to $2,000 \mathrm{ft}$ deep) limits the degree of saturation in the other valleys and structural relief effectively isolates the fill of each valley. Discharge from saturated valley-fill units is by leakage to underlying aquifers, ultimately to the lower carbonate aquifer.

\section{Regional Groundwater Movement}

Lateral groundwater movement in the above units is to the south/southwest on a gross regional scale (Figure 6). Local flow directions can be radically different from those derived from a regional potentiometric contour map, particularly in areas dominated by fracture flow. On the regional scale,

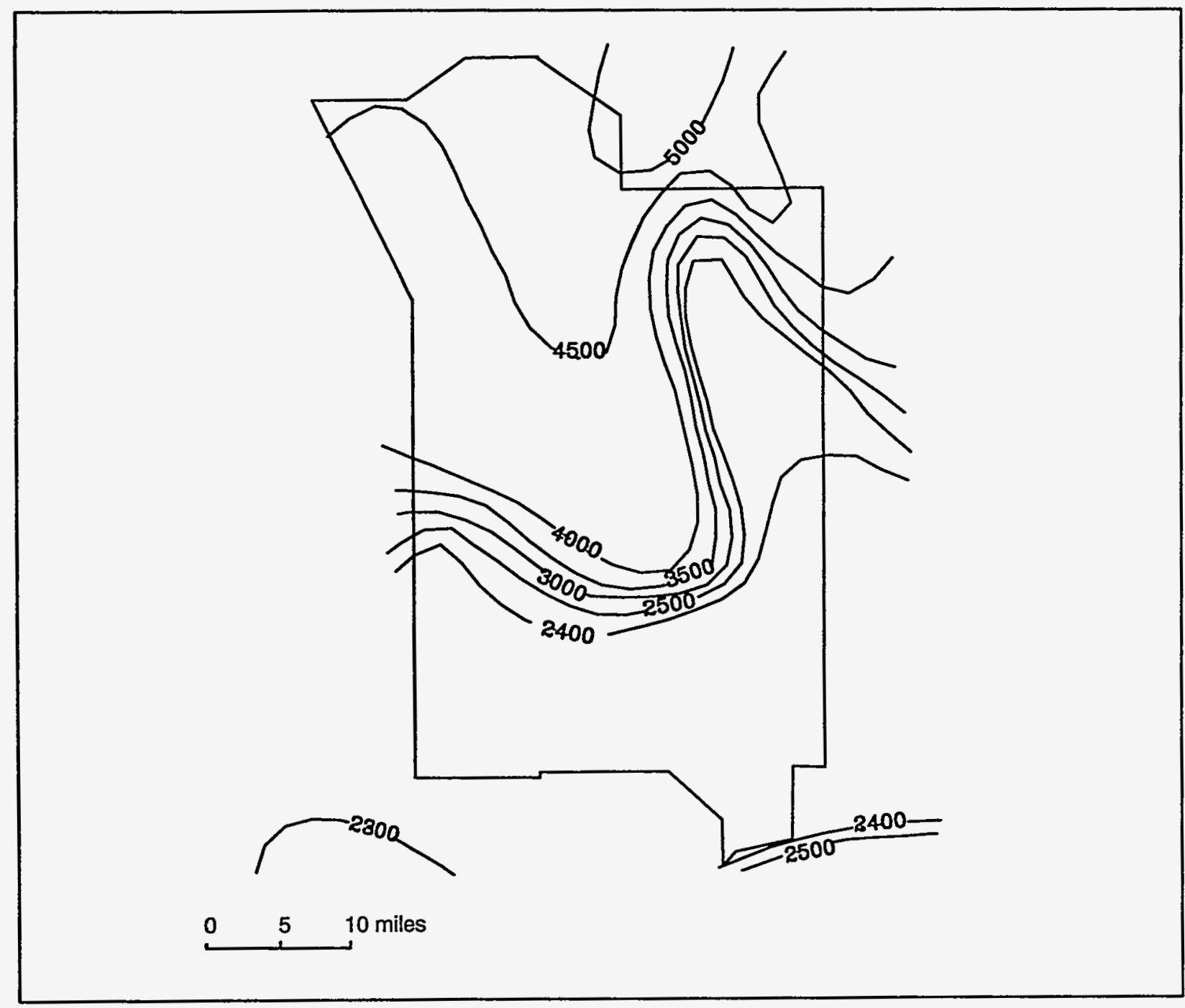

Figure 6. Groundwater table elevation in feet at the Nevada Test Site (from Fenske and Carnahan, 1975). 
flow is from the upland recharge areas in the north and east, toward discharge areas at Ash Springs and Death Valley, southwest of the site. The contours indicating eastward flow from the central part of the site toward Yucca Flat are probably an artifact of the presence of the upper clastic aquitard near the surface in that area. The aquitard creates a hydrologic barrier along the western side of Yucca Flat and any flow across the barrier is probably small in volume. Yucca Flat itself appears to act as a southward flowing drain.

The water-table map (Figure 6) incorporates measurements made in all the aquifers previously discussed. The water table occurs in alluvium, volcanics, or upper or lower carbonates, depending on local structure and outcrop patterns. The depth to the saturated zone is also highly variable, but is generally at least $500 \mathrm{ft}$ below land surface and often more than 1,000 ft (Figure 7). Perched saturated zones occur at more shallow levels in some areas (e.g., Rainier Mesa).

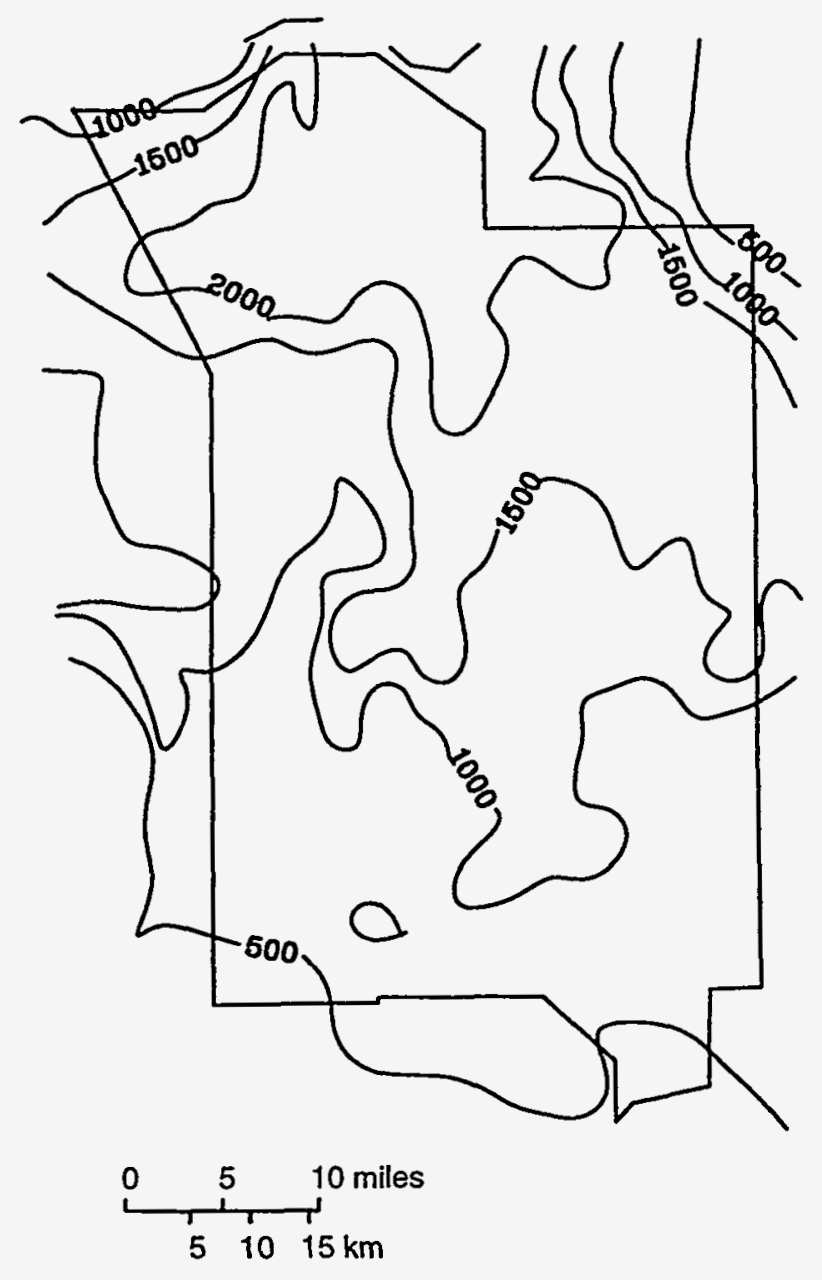

Figure 7. Approximate depth in feet to the water table below land surface at the Nevada Test Site (from Fenske and Carnahan, 1975). 


\section{THE CLASSIFICATION REVIEW AREA}

The groundwater classification process described in the guidance document (U.S. EPA, 1988) is performed on a site-by-site basis rather than applied to aquifers or groundwater regions. However, the classification is independent of the type of facility or site activity proposed. In other words, the classification decision is made based on the groundwater's characteristics, and the same water should have the same classification whether the facility under consideration is a hazardous waste disposal site or a sanitary landfill. The type of facility does play an important role in the classification process in that the boundaries of the site are instrumental in defining the Classification Review Area (CRA) in which classification will take place. The CRA is a review area, not a regulatory area. The EPA does not intend to institute regulatory or permit controls throughout the CRA.

Usually, the CRA is delineated based on a two-mile radius from the facility or activity for which the class determination is being made. A two-mile radius was selected by EPA as appropriate for usually covering the length of the flowpath over which high degrees of interconnection occur and the distance contaminants could be expected to move in problem concentrations if introduced to the groundwater system. The choice of the two-mile radius for the CRA was based on the size of known plumes, survey of distances to downgradient surface water from hazardous-waste facilities, and calculations of pumping well capture zones.

The NTS contains 1,350 square miles of federally owned land with restricted access (Figure 1). The primary activities at the NTS have involved the testing of nuclear explosives. Though testing was initially conducted at or above land surface, all tests since July 1962 at the NTS have been detonated underground. Underground testing has occurred both in the unsaturated zone and below the water table. Other activities now or formerly carried out at the NTS include chemical explosive tests, experiments on biological effects of radionuclide exposure, operation of a prompt burst nuclear reactor, research at the Nuclear Rocket Development Station (NRDS), and nuclear waste experiments (U.S. ERDA, 1977). The RWMS for low-level, mixed, and transuranic waste is also located within the NTS and studies are underway for a possible high-level radioactive waste repository at Yucca Mountain. Most activities at the NTS are conducted in four separate areas: Yucca Flat, Frenchman Flat, Pahute Mesa (including Rainier Mesa), and the NRDS in Jackass Flats.

The number of individual underground nuclear tests (over 600 announced; U.S. DOE, 1990) prohibits defining each event as a separate "site" for classification. Such distinctions would also be redundant as the CRAs determined for many of the events would overlap. Other sites have also been identified, e.g., the RWMS facility, and a leachfield and jet fuel spill near Mercury. The length of time that the NTS has been used, coupled with the classified nature of many activities, leaves open the possibility of additional sites being located at a later time, and the NTS may become the location of other operations as its mission changes. The EPA (1988) notes that the facility boundary should encompass all potentially polluting activities, so DOE/NV has decided to classify groundwater throughout the entire NTS. It should be noted that this decision effectively establishes a buffer between NTS activities and off-site areas that in most cases is much more than the two miles intended 
by the EPA (the exceptions being eastern Frenchman Flat and western Pahute Mesa where activity has occurred very close to or at the NTS boundary).

\section{Expansion of the Classification Review Area}

The EPA suggests expanding the CRA whenever a two-mile radius is considered insufficient for characterizing groundwater potentially affected by a facility. They generally intend expansion when conditions are likely to result in the transport of contaminants beyond two miles during a period of 10 years or less, and relate this to groundwater velocities exceeding 1,000 feet per year (ft/yr) over a substantial distance (U.S. EPA, 1988). The guidance document suggests that such high-velocity groundwater is most likely to be found in either karst, fractured rock, extrusive igneous rock, or coarse-grained aquifers found in alluvium, coastal areas, and glacial outwash settings.

The NTS hydrogeologic system includes several of these candidate settings: a carbonate aquifer known to have solution openings in areas downgradient from the NTS, fractured rock aquifers in both carbonate and volcanic material, and groundwater occurring in alluvial basin materials. The key factor for deciding if the CRA should be expanded is the groundwater velocity.

\section{Groundwater Flow Velocities at the Nevada Test Site}

Winograd and Thordarson (1975) calculated the groundwater velocity in the lower carbonate aquifer beneath central Yucca Flat using estimates of the flow through the aquifer, the cross-sectional area of flow, and the effective porosity. The porosity is considered to be entirely from fractures and is the most uncertain variable in the calculation. Using an effective fracture porosity range from 1.0 to 0.01 percent and estimates of the discharge and cross-sectional areas of flow, Winograd and Thordarson (1975) calculated a velocity range of 0.02 to $2.0 \mathrm{ft} /$ day $(7.3$ to $730 \mathrm{ft} / \mathrm{yr}$ ). Borg et al. (1976) believe that the average effective porosity is near the upper end of the range, or possibly even higher, favoring the lower velocity number.

Estimates of flow rates in the lower carbonate aquifer beneath the Specter Range (Figure 5), south of the NTS, are much higher (two to $200 \mathrm{ft} /$ day or 730 to $73,000 \mathrm{ft} / \mathrm{yr}$ ) (Winograd and Thordarson, 1975). Part of the reason is that the cross-sectional area of flow is constricted by outcrops of the lower clastic aquitard. Additionally, the fracture transmissivity of the carbonates is high beneath the range because of intense structural deformation. Though other areas of extreme fracturing undoubtedly exist, Winograd and Thordarson (1975) believe such zones are discontinuous due to the combined effects of erosion and offset by Tertiary block faulting. Flow estimates even farther downgradient, between the Specter Range and the springs at Ash Meadows, are 0.16 to $3.7 \mathrm{ft} /$ day ( 58 to $1,350 \mathrm{ft} / \mathrm{yr}$ ) in the Bonanza King Formation (corrected values of Claassen and Cordes, 1975, as reported in Borg et al., 1976). This estimate is based on a two-well recirculating tracer test and thus contains less uncertainty in the effective porosity value than velocities calculated by Winograd and Thordarson (1975). Hydraulic gradients are steeper in this downgradient area than those determined within the NTS in Yucca Flat.

In the western part of the NTS, the water table occurs in volcanic units. This area may be part of a groundwater flow system separate from the carbonate system discharging at Ash Meadows. 
Blankennagel and Weir (1973) estimate the flow rate in the volcanics beneath Pahute Mesa to be between 0.02 and $0.7 \mathrm{ft} /$ day (7.3 $-256 \mathrm{ft} / \mathrm{yr})$. As with Winograd and Thordarson's estimates, the range in values is primarily caused by uncertainty in the effective fracture porosity. Velocities in the upper water-bearing tuff units beneath Yucca Mountain (at the southwest edge of the NTS) have been calculated by DOE (1988) and are $0.9 \mathrm{ft} /$ day ( $329 \mathrm{ft} / \mathrm{yr}$ ) for tuffaceous beds of the Calico Hills unit and $0.1 \mathrm{ft} /$ day $(36.5 \mathrm{ft} / \mathrm{yr}$ ) for the Topopah Spring Member. Thus, the flow rates in the lower carbonate aquifer probably represent the worst case scenario (fastest flow) in the hydrogeologic units beneath the NTS.

There is a large degree of uncertainty associated with all of the groundwater velocities given above. Much of the uncertainty stems from lack of data on the effective porosity of fractured units. Borg et al. (1976) point out the very tentative nature of Winograd and Thordarson's (1975) groundwater velocity estimates and caution that those estimates have gained an unjustified aura of authority due to the lack of new data.

\section{Summary}

Calculations of groundwater velocity for aquifers within the NTS indicate that a two-mile CRA boundary will encompass the area expected to be impacted by contaminant transport during a 10-year period. Though faster velocities have been estimated for regions downgradient from the NTS, expansion of the CRA is not warranted, particularly since most NTS activities take place many miles inside the site boundary. In addition, the velocities considered above are for groundwater within aquifers located hundreds of feet below the ground surface. With the exception of nuclear tests conducted below the water table, any migration of contaminants from most NTS facilities must first traverse a thick unsaturated zone where downward flow (if any) is very slow.

The CRA for the NTS is shown on Figure 8. Two points should be kept in mind when considering the CRA. First, the area is very large as a consequence of the large size of the NTS and DOE/NV's decision to classify the entire site and not just specific testing areas. Thus, the classification process bears more similarity to regional groundwater classification than to the site-specific classification that will occur at smaller facilities (e.g., a landfill). Second, for most sites within the NTS, the CRA chosen provides much more than the two-mile buffer required by the EPA. This is the result of the DOE's decision to classify all of the NTS, since most activities are located many miles upgradient of the NTS boundary. The CRA is considered to be sufficiently large to allow confident determination of the use and value of groundwater and identification of potentially affected users.

\section{HYDROGEOLOGIC SUBDIVISIONS OF THE NTS CRA}

One of the initial assumptions in the classification process is that all groundwater within the CRA is highly connected hydrologically (both vertically and horizontally) to any site activity. If data indicate that this assumption is incorrect, the CRA can be subdivided into groundwater units (mappable, three-dimensional bodies of groundwater) to more accurately depict the interconnection between groundwater associated with site activities and other groundwater in the CRA. All 


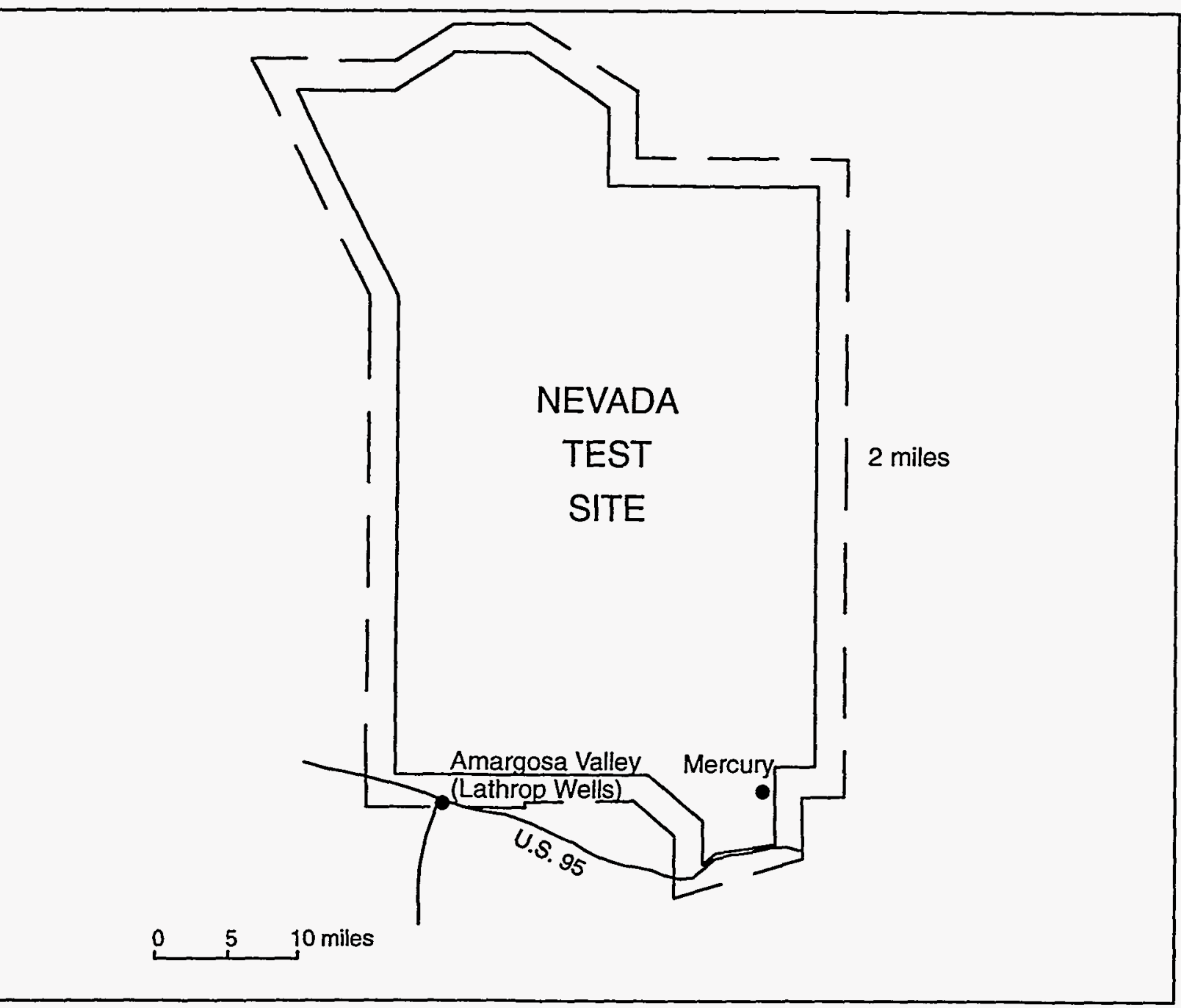

Figure 8. The Classification Review Area (CRA) for the Nevada Test Site. The CRA extends two miles outside the NTS boundary.

groundwater within a single unit must have the same classification and boundaries separating waters of different classes must coincide with unit boundaries. Different units, however, may have the same class designation, even if they are adjacent to each other.

The EPA recognizes four types of boundaries between groundwater units (U.S. EPA, 1988). These boundary types, along with the degree of hydrogeologic interconnection assigned by the EPA to each type of boundary, are as follows:

Type

1

2

3

4
Description permanent groundwater flow divides extensive low permeability units (aquitards) permanent freshwater-saline water contacts hydraulic gradient-based boundary
Degree of Interconnection intermediate

low intermediate intermediate 
Type 2 boundaries dominate the hydrogeologic system in the CRA, though some of these incorporate some Type 1 characteristics. As no saline water (>10,000 mg/L TDS) has been identified within the NTS CRA, Type 3 boundaries will not be discussed. Type 4 boundaries establish a region that will always remain upgradient of the facility or activity within the CRA. The variety of locations of past, current, and future activities at the NTS make it impractical to include Type 4 boundaries in a general classification process. Such boundaries could be identified for specific locations within the NTS, if an activity-specific classification is ever desired.

The first step suggested by the EPA for subdividing the CRA is the identification of aquifers. Specific aquifers and aquitards are both introduced and briefly described in an earlier section. To summarize, the flow system can be divided into an eastern part (Ash Meadows groundwater subbasin) and western part (Alkali Flat-Furnace Creek Wash and Oasis Valley groundwater subbasins). The hydraulic basement is formed by low-permeability units of the lower clastic aquitard. The lower carbonate aquifer is the most regionally extensive hydrologic unit and probably provides for interbasin groundwater flow across the eastern part of the site. Structural and volcanic features have limited the connection between the lower carbonate aquifer on the east and west sides of the CRA. The low-permeability volcanic aquitard separates the lower carbonate aquifer from overlying units. The volcanic and valley-fill aquifers probably behave as one hydrogeologic unit, with their degree of saturation controlled by the basin-and-range structure and topography. The volcanic and valley-fill aquifers also have separate east and west flow systems, similar to that found in the carbonate aquifer.

On the basis of the site hydrogeologic setting, the boundaries that must be justified are as follows:

- Type 2 contact between lower clastic aquitard and the lower carbonate aquifer (boundaries 2 and 3 on Figure 9)

- Type 2 contact between the lower carbonate aquifer on the east and west sides of the CRA (boundary 1 on Figure 9)

- Type 2 contact between the lower carbonate aquifer and the Cenozoic aquifer systems (volcanic and valley-fill) (cannot be seen in map view)

- Type 2 contact between the Cenozoic aquifer system on the east and west sides of the site and between the Cenozoic aquifer system in adjacent basins (boundaries 4, 5, and 6 on Figure 9).

The hydrogeologic subdivisions created by these boundaries are introduced on Figure 9 . Supporting evidence for the subdivisions is discussed in the following sections.

\section{Approach to Boundary Justification}

The classification guidance document (U.S. EPA, 1988) describes the type of evidence expected for each type of boundary. Aquitard boundaries (Type 2) should be justified on the basis 
Lower Carbonate Aquifer

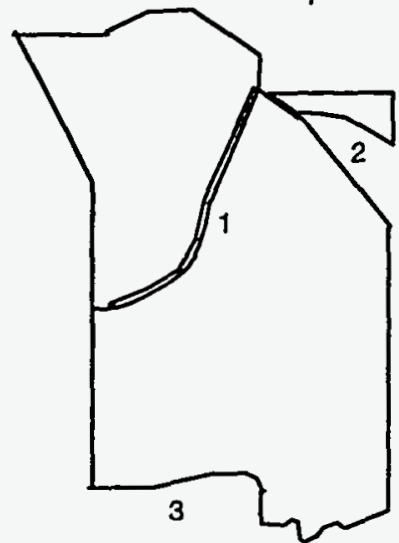

Cenozoic Aquifer System

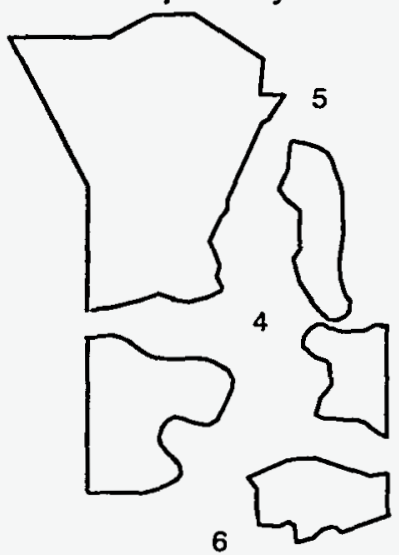

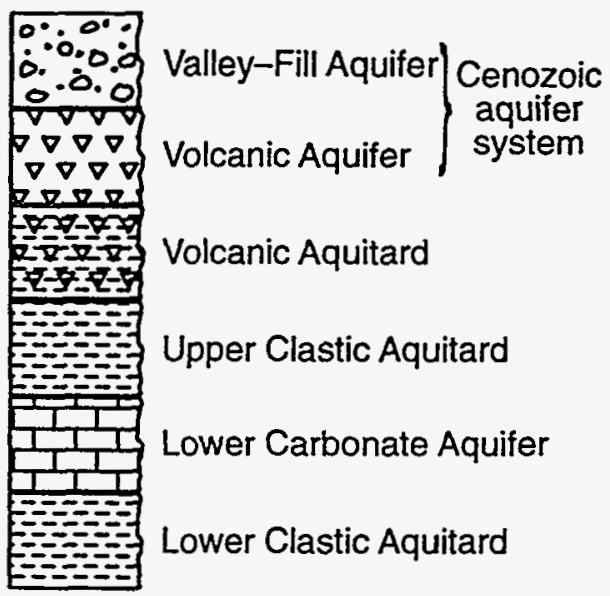

Created by

Boundary

1

2 Lower Clastic Aquitard

3 Lower Clastic Aquitard

$4 \quad$ Upper Clastic Aquitard and Volcanic Aquitard

$5 \quad$ Lower Clastic Aquitard and Volcanic Aquitard

$6 \quad$ Lower Clastic Aquitard and Volcanic Aquitard

Figure 9. Hydrogeologic subdivisions of the CRA with an idealized stratigraphic column. Blank areas on the map are the locations of boundaries between hydrogeologic units. See text for discussion of the boundaries.

of their stratigraphic setting and lithologic characteristics, structural setting and joint/fracture/fault characteristics, and hydrogeologic setting and hydraulic head and fluid flow characteristics. The EPA concludes that the best evidence is related to the hydrogeologic setting and measured hydraulic parameters. The low permeability unit should be laterally continuous and/or limit the continuity of the adjoining aquifer and should not have improperly abandoned wells or mine shafts through it. A quantitative permeability limit has not been set by the EPA, but the permeability should be significantly lower than that of adjacent units and geologic media in general, and the flow of water through the unit should be insignificant relative to flow in adjacent aquifers. Data on aquitards within the CRA are considered sufficient to establish Type 2 boundaries as suggested by the EPA.

Each of the boundaries listed in the previous section will now be analyzed. The primary source for the information presented below is Winograd and Thordarson (1975).

\section{Type 2 Boundary Between the Lower Clastic Aquitard and the Lower Carbonate Aquifer}

The lower clastic aquitard is interpreted by Winograd and Thordarson (1975) as the hydraulic basement for regional groundwater flow in the NTS area. The unit contains all the clastic rocks 
(siltstone, quartzite, shale, and sandstone) of the Precambrian- to Early Cambrian-age Johnnie Formation, Stirling Quartzite, Wood Canyon Formation, Zabriskie Quartzite, and lower half of the Carrara Formation. The rocks of the lower clastic aquitard have negligible interstitial permeability. The development of secondary porosity along joints is associated with subaerial weathering and is generally absent in the subsurface.

The lower clastic aquitard has been subjected to intense structural deformation. Although this deformation is responsible for the development of the high transmissivities in the lower carbonate aquifer, the aquitard did not develop integrated fracture porosity because of the rock's low susceptibility to dissolution, the tendency of argillaceous rocks to deform plastically, and the tendency of micaceous partings and laminae to seal fractures in the quartzite (Winograd and Thordarson, 1975). Winograd and Thordarson conclude that the slow rate of vertical and lateral movement of water in the lower clastic aquitard is governed by the low interstitial permeability. They cite the absence of springs in the clastic strata as additional evidence for the lack of integrated fracture transmissivity.

The lower clastic aquitard is believed to be laterally continuous beneath most of the CRA, but this has not been confirmed in many areas (particularly the western part of the CRA) because the aquitard occurs at depths exceeding those penetrated by wells. The aquitard may be absent in the western part of the CRA, beneath the Timber Mountain and Silent Canyon calderas (the calderas are discussed in more detail in the next section). The aquitard is at or near the surface in two parts of the CRA (Figure 10). In the northeastern corner of the NTS, the lower clastic aquitard forms a Type 2 boundary against all of the other hydrologic units (boundaries 2 and 5 on Figure 9). In that area, the lower clastic aquitard is exposed at or near the surface from the Climax Stock at the north end of Yucca Flat, eastward along the Halfpint Range for about 12 miles, then northward along the Groom and Papoose ranges for about 25 miles (Figure 5). This exposure creates a Type 2, low permeability barrier between the lower carbonate aquifer and the Cenozoic aquifer system in Yucca Flat and between the same units northeast of the clastic outcrop. Evidence of this barrier can be found in the much higher water levels in units north of the barrier (generally 2,000 $\mathrm{ft}$ higher than head values in Yucca Flat, compare Figures 10 and 11), in the gentle eastward slope of the hydraulic gradient in the Cenozoic units toward Groom Lake Playa, and in the steep hydraulic gradient indicated across the aquitard (1,300 ft/mi) (Figure 11). Winograd and Thordarson (1975) calculate that leakage across the lower clastic aquitard in northern Yucca Flat is probably less than 40 acre-ft/yr. They conclude that the lower clastic aquitard is an effective hydraulic barrier and that despite large differences in head across the aquitard, there is little movement of water across the barrier in the lower carbonate aquifer in western Emigrant Valley.

Outcrops and near-surface expressions of the lower clastic aquitard also occur in the southernmost part of the CRA (boundaries 3 and 6 on Figure 9). These help to funnel flow in the lower carbonate aquifer in the eastern part of the area through the highly fractured Specter Range toward the discharge area at the Ash Meadows springs. The area of the lower clastic aquitard southwest of Rock Valley also separates flow moving through aquifers on the western side of the NTS from that discharging at Ash Meadows. 


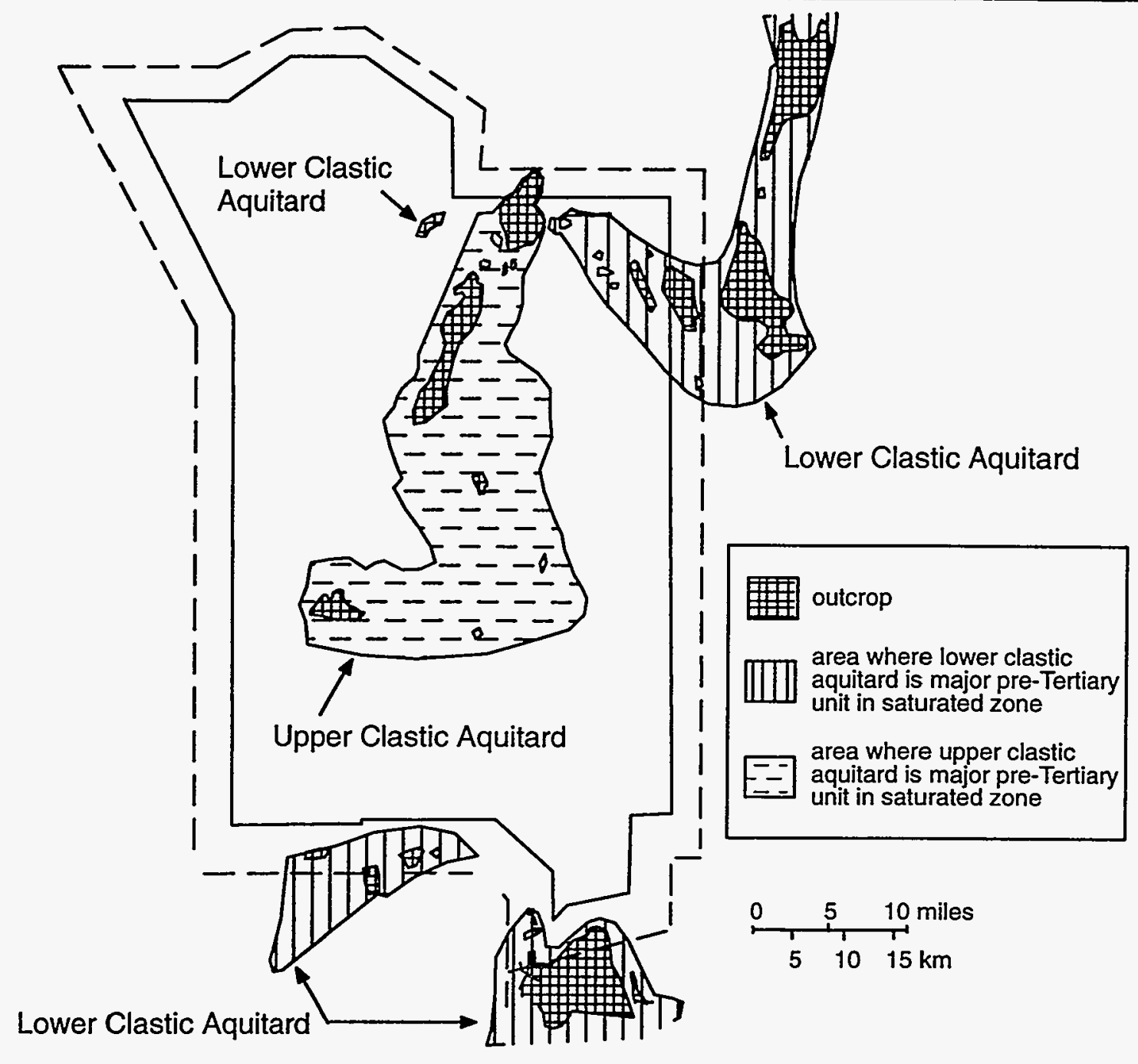

Figure 10. Lower and upper clastic aquitards. Outcrops of respective aquitards shown in block pattern. Hachured areas encompass inferred area in which the respective aquitard is the major pre-Tertiary hydrogeologic unit within the zone of saturation (or upper several thousand feet of saturated zone for the upper clastic aquitard) (from Winograd and Thordarson, 1975).

Hydraulic data are available from the lower clastic aquitard from over 3,500 ft of core from one well, and from three well tests. Tests on 18 core samples yielded hydraulic conductivity values from $7 \times 10^{-7}$ to $1 \times 10^{-4} \mathrm{gpd} / \mathrm{ft}^{2}$, with a mean of $1 \times 10^{-5} \mathrm{gpd} / \mathrm{ft}^{2}$ (Winograd and Thordarson, 1975). The pumping and bailing tests were performed in wells in Mercury Valley, southwestern Rock Valley, and northern Yucca Flat. Because the tests penetrated different thicknesses of rock, Winograd and Thordarson (1975) normalized values to $1,000 \mathrm{ft}$ of saturated rock and found a range in specific capacities of 0.04 gallons per minute per foot $(\mathrm{gpm} / \mathrm{ft}$ ) of drawdown in the Rock Valley well to 0.1 $\mathrm{gpm} / \mathrm{ft}$ of drawdown in the Mercury Valley well. The well tested in northern Yucca Flat penetrated down past a fracture zone at the contact of the Johnnie Formation and the Noonday (?) Dolomite. 


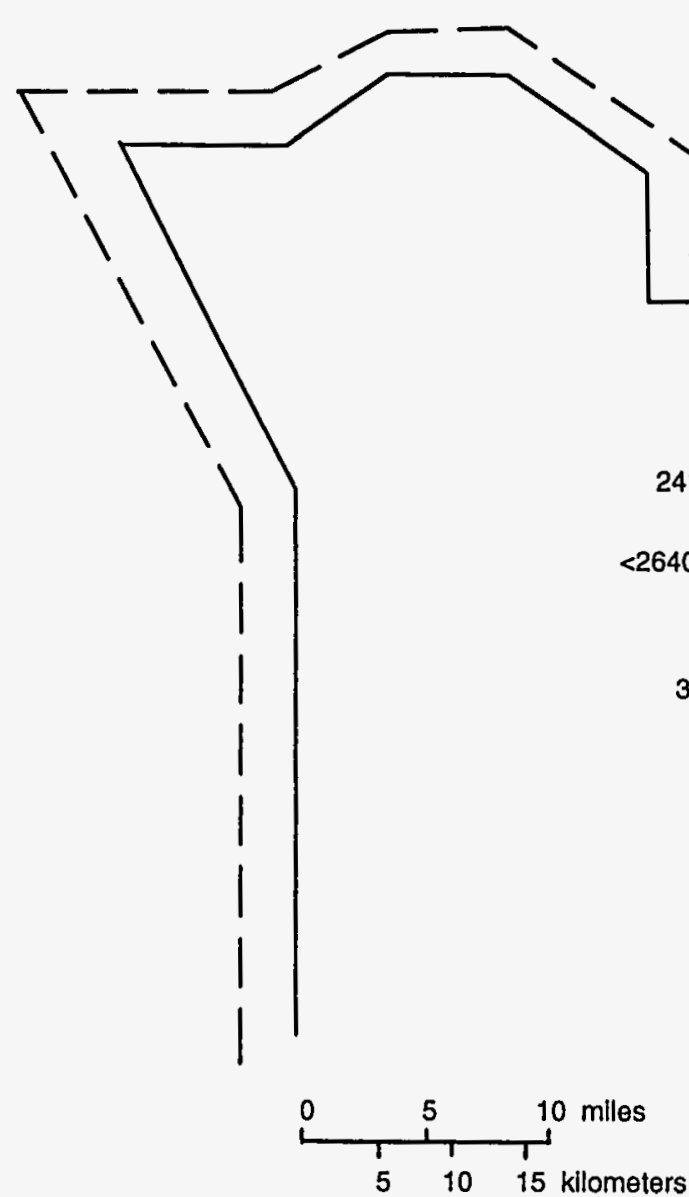

variable contour interval, In feet above mean sea level

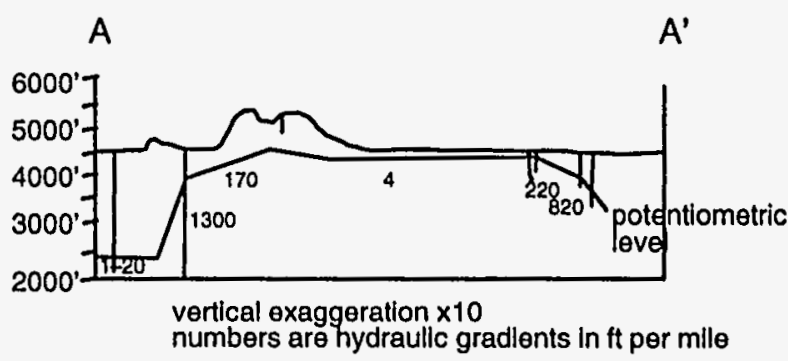

potentiometric contour in Carbonates

- . - - potentiometric contour in Cenozoic Aquifers

屯. 2345 head in Lower carbonate aquifer

2345 head in Cenozoic aquifer system (volcanic and valley-fill)

申. $2345 / 2360$ head in carbonates/head in Cenozoics

Figure 11. Detail of hydrogeologic conditions in the northeastern part of the Nevada Test Site, near the outcrop of the lower clastic aquitard (from Winograd and Thordarson, 1975). 
Excluding this underlying fracture zone, the overlying $3500 \mathrm{ft}$ of the lower clastic aquitard yielded a normalized specific capacity of no greater than $0.08 \mathrm{gpm} / \mathrm{ft}$ of drawdown, suggesting a transmissivity of $150 \mathrm{gpd} / \mathrm{ft}$ for a normalized 1,000-ft section of aquitard. For comparison, the transmissivity of the lower carbonate aquifer is estimated to range from 1,000 to $900,000 \mathrm{gpd} / \mathrm{ft}$ (Table 2).

TABLE 2. Range of Transmissivity and Specific Capacity of Aquifers and Aquitards.

\begin{tabular}{lcc}
\hline \hline \multicolumn{1}{c}{ Unit } & $\begin{array}{c}\text { Transmissivity } \\
\text { (gpd/ft) }\end{array}$ & $\begin{array}{c}\text { Specific Capacity } \\
\text { (gpm/ft) }\end{array}$ \\
\hline Valley-fill aquifer & 800 to 34,000 & 1.3 to 30 \\
Volcanic aquifer & 200 to 100,000 & 0.1 to 56 \\
Volcanic aquitard & 100 to 200 & 0.01 to $3^{*}$ \\
Upper clastic aquitard & $<500$ & $0.83 \dagger$ \\
Lower carbonate aquifer & 1,000 to 900,000 & 0.4 to 530 \\
Lower clastic aquitard & $<1,000$ & 0.04 to $0.1^{*}$ \\
\hline \hline
\end{tabular}

*Values normalized to $1,000 \mathrm{ft}$ of saturated rock.

fUnits reported by Winograd and Thordarson (1975) are $\mathrm{gpd} / \mathrm{ft}$, but as all other capacities are in gpm/ft of drawdown, the reported units might be incorrect.

Note: All values from Winograd and Thordarson (1975).

\section{Type 2 Boundary in the Lower Carbonate Aquifer}

Though the lower carbonate aquifer is the most continuous aquifer in the CRA, numerous hydraulic barriers created by faults and clastic rocks suggest that it is best viewed as a compartmentalized aquifer system (Winograd and Thordarson, 1975). The tightness of these barriers is variable and in most cases does not justify assigning a boundary condition for classification purposes, with one exception. This exception is the flow boundary that corresponds with the dividing line between the Ash Meadows groundwater flow system in the eastern part of the CRA and the Alkali Flat-Furnace Creek Ranch flow system in the western part.

The northwestern border of the Ash Meadows Groundwater Basin is generally defined by the highlands formed on the Belted Range, Rainier Mesa, and the Eleana Range. The northern and central border is formed by a combination of two structural features and two volcanic features (Figure 12). The two structural features are north-south-trending thrust faults. The easternmost fault is the Tippinip thrust fault, bordering exposures of the upper clastic aquitard. In some areas, parts of the lower carbonate aquifer have been thrust over the upper clastic aquitard, becoming isolated from equivalent carbonate units in Yucca Flat. This separation is evidenced by the extreme difference in head levels (approximately 2,400 ft in Yucca Flat and over 4,000 ft west of the fault). However, the upper clastic aquitard is probably underlain by thousands of feet of the lower carbonate aquifer, so that the effectiveness of the Tippinip thrust fault as a hydraulic barrier depends in part 


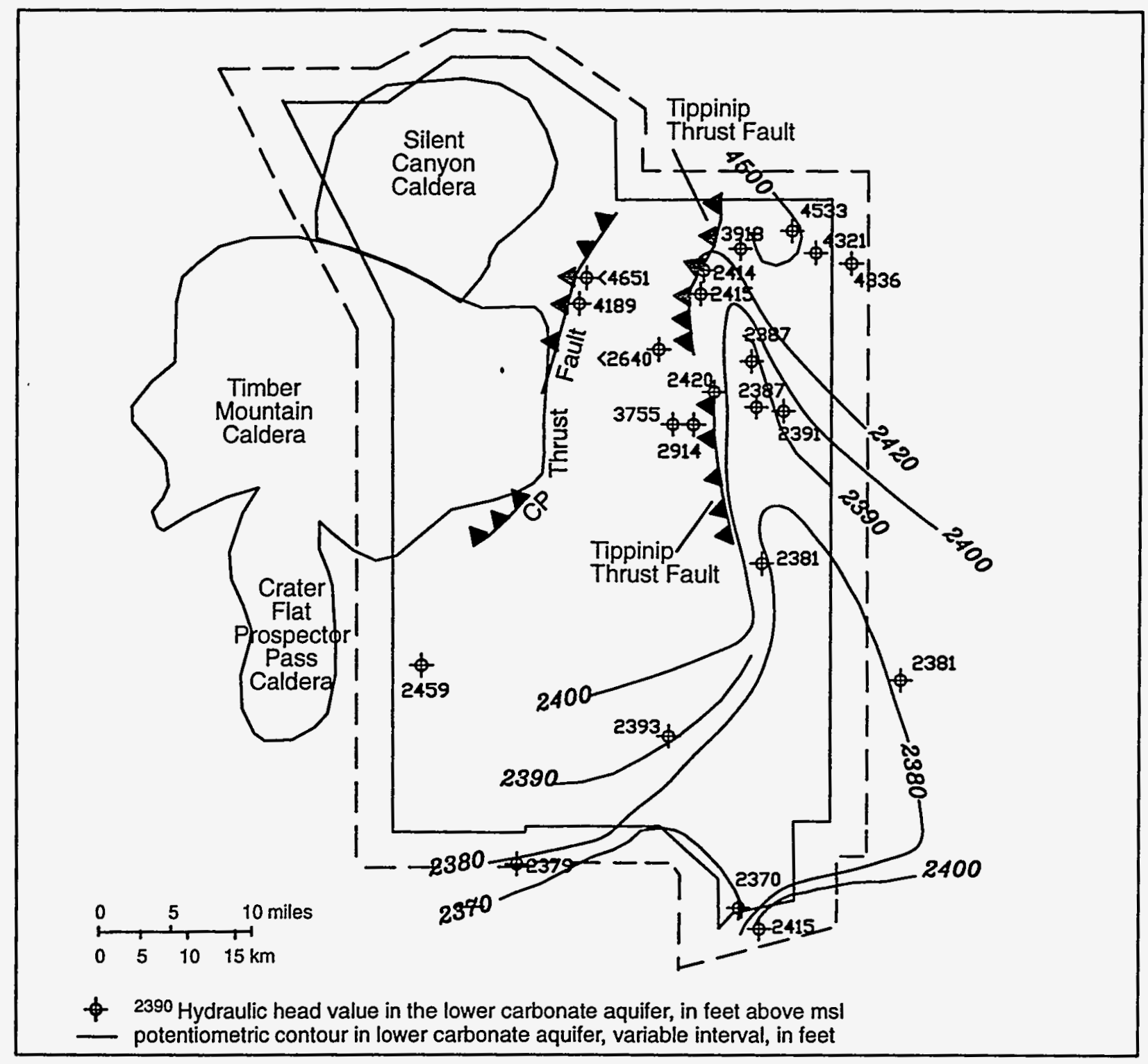

Figure 12. Hydraulic head values in the lower carbonate aquifer. All head values from Winograd and Thordarson (1975), with the exception of the one east of Crater Flat-Prospector Pass Caldera, which is from Waddell et al. (1984). All contours from Winograd and Thordarson (1975). Caldera locations from Maldonado (1985).

on how steeply the fault dips in the subsurface. If it dips steeply for several thousand feet, it could be an effective barrier, even for flow at great depths in the lower carbonate aquifer.

The second, western, structural feature is the CP Thrust Fault, which extends approximately from the northern NTS boundary to northwestern Jackass Flats. This fault may be rooted in Precambrian clastic rocks (Barnes and Poole, 1968), and thus could isolate the lower carbonate aquifer on either side of the fault. 
To the west of the faults, two large calderas cover the northwestern part of the CRA. The Silent Canyon Caldera is centered beneath Pahute Mesa and the Timber Mountain Caldera is located to the south of it. Whether the lower carbonate aquifer occurs at depth beneath these caldera deposits, or if the calderas are underlain by magma chambers, is unknown. No pre-Tertiary rocks have been penetrated during drilling in this area. The closest Paleozoic exposures occur 10 miles north and eight miles east-southeast of the calderas. Blankennagel and Weir (1973) do not believe carbonates exist beneath the calderas and conclude that the lower carbonate aquifer in western Yucca Flat and northern Jackass Flats is not laterally continuous with any carbonate rocks occurring at great depth outside the calderas. Cauldron subsidence at the Silent Canyon Caldera has left a Tertiary volcanic section of ash-flow and ash-fall tuffs and lava flows at least 13,000 ft thick (Blankennagel and Weir, 1973). The Timber Mountain Caldera is believed to be underlain by at least $12,000 \mathrm{ft}$ of volcanics (Winograd and Thordarson, 1975).

The volcanic and structural features just described, and the westward direction of groundwater flow in the Volcanic Aquifer on Pahute Mesa (Figures 13 and 14), provide strong evidence that the lower carbonate aquifer beneath western Yucca Flat and northern Jackass Flats is not structurally or hydraulically continuous with the lower carbonate aquifer (if any) beneath the calderas or the areas west and north of the calderas (Winograd and Thordarson, 1975) (boundary 1 on Figure 9).

The groundwater basin boundary between the Ash Meadows flow system and the Alkali Flat-Furnace Creek Ranch flow system probably continues from the well-defined boundary along the calderas and structural features just described to the outcrops and near-surface exposures of the lower clastic aquitard east of Amargosa Valley. Winograd and Thordarson (1975) show a tentative position for this boundary on their Plate 1. The presence of such a boundary is likely, as water in the lower carbonate aquifer in the western part of Jackass Flats probably moves southward into the Amargosa Desert rather than toward Mercury Valley and then to Ash Meadows. Workers since Winograd and Thordarson (1975) have also identified this basin boundary, though the location varies from author to author (Figure 15). Head data from the carbonate aquifer are lacking in the southern part of the CRA, accounting for the variability in the boundary's interpreted location. This part of the division between an east and west flow system in the lower carbonates could be a Type 1 flow divide boundary as opposed to the aquitard boundary found north and south of the Rock Valley-Skull Mountain area. The EPA (1988) requires that Type 1 boundaries be shown to have a high degree of spatial permanence through time. The few data available cannot prove that a permanent, fixed, flow boundary exists in this area. The possibility of the boundary migrating in time (most likely from climate change rather than pumping) is also suggested by the various locations assigned to the boundary. The uncertainty in the boundary location, and in the permanence of its location, prevent classifying this boundary according to the EPA guidelines. Therefore, until additional head data are available, the lower carbonate aquifer in the southern part of the NTS must be considered as one highly interconnected unit. 


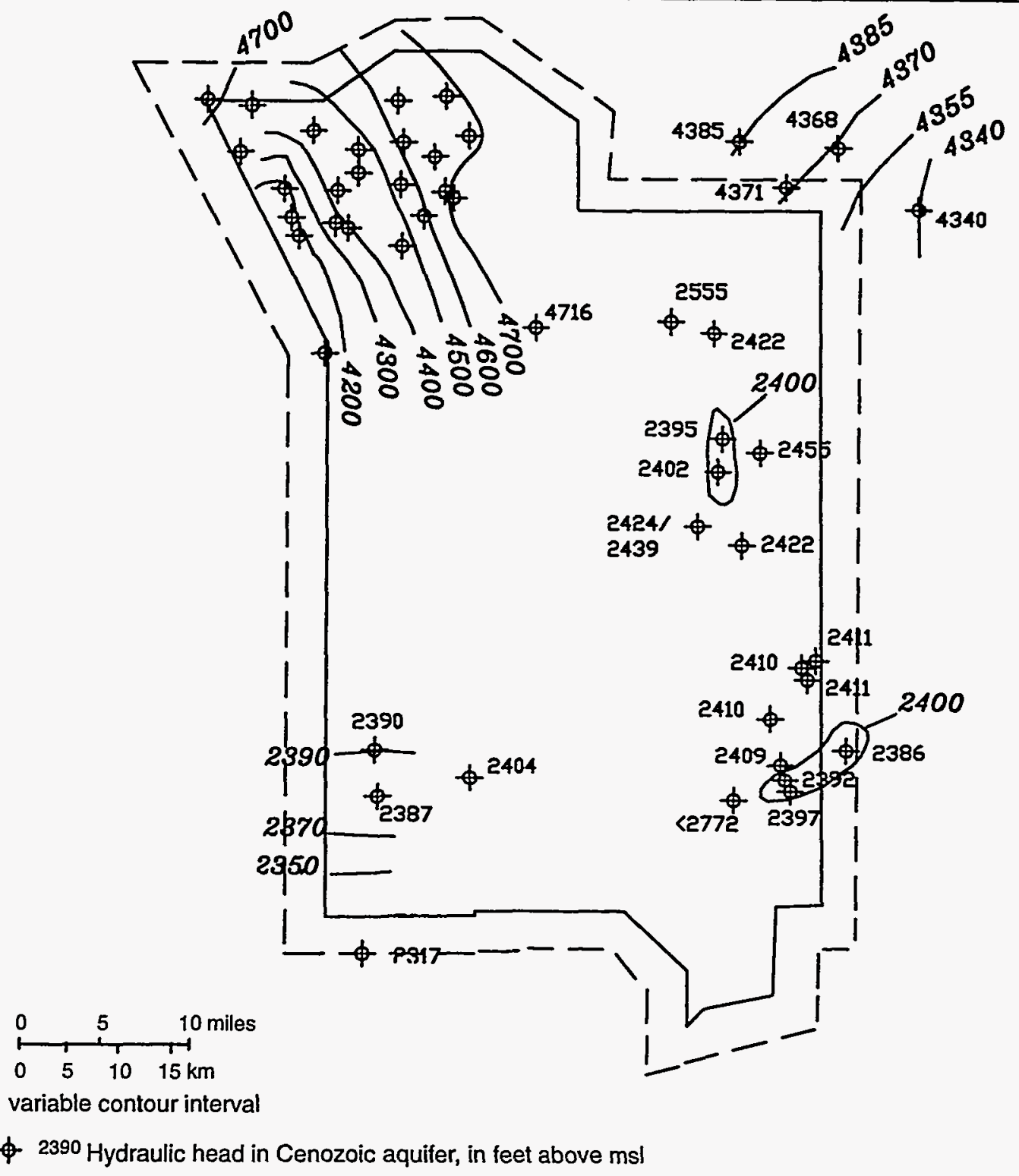

Figure 13. Hydraulic head values in the Cenozoic aquifer system (volcanic and valley-fill aquifers). From Winograd and Thordarson (1975). For individual head values on Pahute Mesa, please see Figure 14.

Type 2 Boundary Between the Lower Carbonate Aquifer and Overlying Cenozoic Aquifer System

The flow systems in the Paleozoic carbonates and in the Cenozoic volcanics and alluvium are separated, though not isolated, by the volcanic aquitard. The volcanic aquitard includes both the tuff aquitard and lava-flow aquitards of Winograd and Thordarson (1975), with the tuff aquitard being the most laterally extensive. The tuff aquitard contains all tuffs and associated rocks older than the 


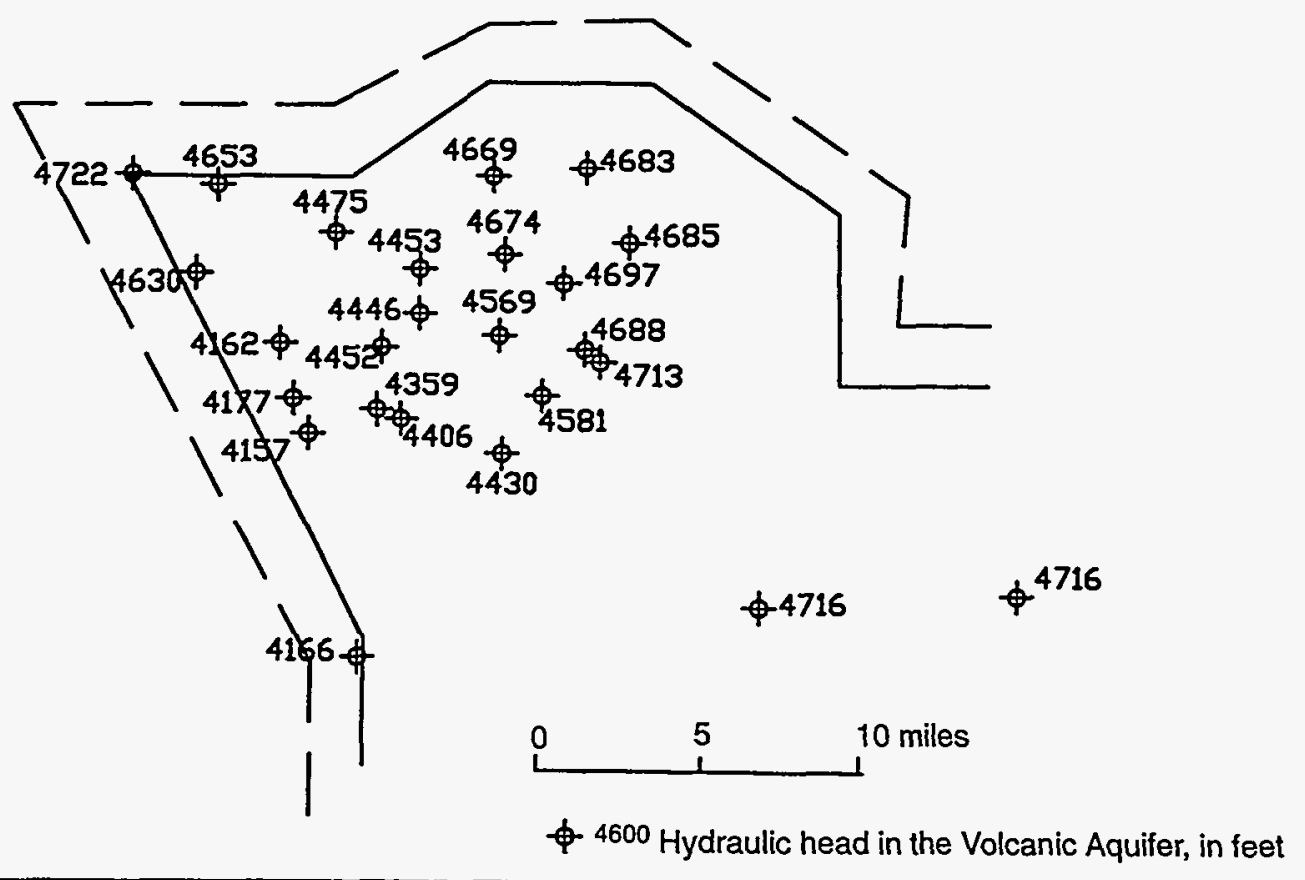

Figure 14. Hydraulic head values in the Cenozoic-age volcanic aquifer on Pahute Mesa (from Winograd and Thordarson, 1975).

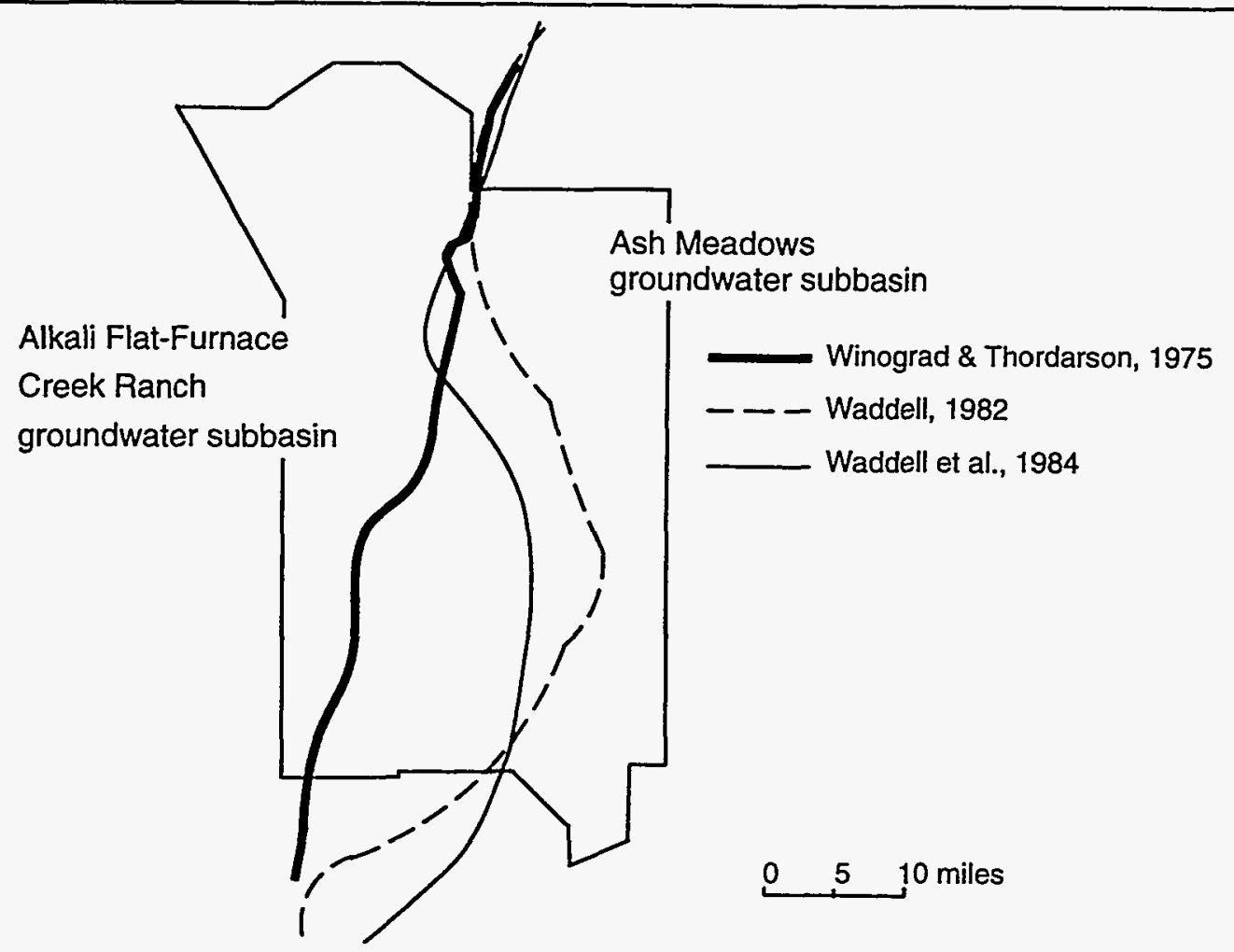

Figure 15. Location of boundary between the Ash Meadows groundwater subbasin and the Alkali Flat-Furnace Creek Ranch groundwater subbasin, according to various authors. 
Paintbrush Tuff. These formations contain a wide variety of lithologies (e.g., nonwelded to incipiently welded ash-flow tuff, ash-fall (bedded) tuff, tuff breccia, breccia flow, tuffaceous sandstone, siltstone, mudstone, and freshwater limestone). A feature common to the aquitard strata is matrices filled with zeolite and/or clay minerals. These matrix minerals are responsible for the low interstitial permeability.

The volcanic aquitard is present across much of the site, though it can be missing in the vicinity of buried pre-Tertiary structural highs. In the intermontane basins, the aquitard is very thick. It is up to 2,000 ft thick in central Yucca Flat, over 2,000 ft thick in western Jackass Flats, and over 4,500 $\mathrm{ft}$ thick in Frenchman Flat. In valleys with deep water tables (500 to 2,000 ft below land surface), the volcanic aquitard surrounds as well as underlies the volcanic and valley-fill aquifers at the altitude of the water table. These valleys include Yucca Flat, Frenchman Flat, Jackass Flats, and Mercury Valley.

The hydraulic characteristics of the volcanic aquitard have been determined by testing in cores and wells. Analyses have been performed on 72 cores. Zeolitized tuff yielded a range in permeability of $5 \times 10^{-5}$ to $6 \times 10^{-1} \mathrm{gpd} / \mathrm{ft}^{2}$, with a mean of $5 \times 10^{-2}$. Clayey tuff and sediments had a permeability range of $2 \times 10^{-6}$ to $4 \times 10^{-1}$, with a mean of $2 \times 10^{-2}$. The bailing, swabbing, and injection tests reveal hydrologic properties controlled by fractures. The range of specific capacities from the well tests is 0.01 to $3.0 \mathrm{gpm} / \mathrm{ft}$ of drawdown per $1,000 \mathrm{ft}$ of penetration. The higher values in this range are above the arbitrary division between aquitard and aquifer assigned by Winograd and Thordarson (1975) (0.1 gpm/ft for 1,000 ft of saturated rock). However, Winograd and Thordarson (1975) believe that the relatively high specific capacities represent very localized and short-term conditions caused by rapid drainage of fractures. The median specific capacities suggest a transmissivity of about 100 to $200 \mathrm{gpd} / \mathrm{ft}$. Observations of the tuff aquitard in tunnels in Rainier Mesa support the conclusion that fracture zones are poorly connected and dewatered rapidly.

The barrier imposed by the volcanic aquitard is not absolute; indeed, leakage through the aquitard is interpreted to be the primary mechanism for discharge for groundwater in the overlying volcanic and valley-fill aquifers across the eastern and southern parts of the CRA into the lower carbonate aquifer. However, calculations of groundwater velocity yield average vertical velocities of $5 \times 10^{-4}$ to $2 \times 10^{-1} \mathrm{ft} / \mathrm{yr}$. Assuming an average saturated thickness of $1,000 \mathrm{ft}$, the time for a water molecule to pass through the aquitard is anywhere from 6,000 to $2,000,000$ years. Despite the large uncertainties present in such a calculation based on limited data, it is clear that water flow through the aquitard is severely retarded relative to that in the adjacent aquifers.

The hydrologic criteria that the EPA emphasizes for Type 2 boundaries are that the unit has a small permeability relative to adjacent geologic units and to geologic media in general, and that the flow of water through the aquitard per unit area is insignificant relative to the flow of water per unit area in adjacent aquifers. The characteristics of the volcanic aquitard and its relationship with the lower carbonate aquifer and the Cenozoic aquifer system qualify it as a Type 2 boundary. It should not be forgotten, however, that downward leakage through the aquitard does occur and is important to the flow system in a regional sense. 


\section{Type 2 Boundary Between the Cenozoic Aquifer System in the East and West Sides of the CRA and From Valley to Valley}

The long north-south outcrop exposures of the upper clastic aquitard (the Eleana Formation) (Figure 10) separates the flow system in the volcanic and valley-fill aquifers east of those outcrops from those occurring to the west (boundary 4 on Figure 9). The Eleana is stratigraphically below the Cenozoic aquifer system in an undisturbed section. The upper clastic aquitard beneath western Yucca Flat and northern Jackass Flats is thousands of feet thick. The Eleana Formation contains argillite, quartzite, and conglomerate. Primary porosity has a mean value of 7.6 percent, while the mean effective porosity is 4.2 percent. Secondary porosity is poorly developed and has only been detected in outcrops subjected to subaerial weathering. The Eleana is believed to have responded to deformation plastically by shearing and tight folding, as evidenced by its location as the principal glide plane for several major thrust faults (Winograd and Thordarson, 1975).

Hydraulic testing of the aquitard in Yucca Flat included $84 \mathrm{ft}$ of dolomite, resulting in a specific capacity of $0.83 \mathrm{gpd} / \mathrm{ft}$ of drawdown per $1,000 \mathrm{ft}$ of saturated rock. Aquifer testing of the Eleana Formation in boreholes on Syncline Ridge yielded very low transmissivities. While most values were too low for the test methods used, a transmissivity value of $49.5 \mathrm{ft}^{2} /$ day was determined for one borehole and a value of $1.1 \mathrm{ft}^{2} /$ day in another (Dinwiddie and Weir, 1979). The flow separation caused by the outcrop of the upper clastic aquitard is evidenced by the hydraulic gradients on either side of the aquitard (Figure 13). East of the aquitard, water levels in the volcanic and valley-fill aquifers are less than 2,500 ft above mean sea level, and gradients indicate flow toward valley centers. West of the aquitard, the valley fill is unsaturated and water levels in the volcanics are greater than 4,000 ft in elevation. Gradients in the volcanics on Pahute Mesa are fairly well established, with flow being directed to the west and southwest (Blankennagel and Weir, 1973) (Figures 13 and 14).

Whereas an east-west division of the lower carbonate aquifer in the southern part of the NTS could not be proven using the EPA guidelines, a boundary can be identified in this area for the volcanic aquifer (boundary 4 on Figure 9). This boundary also holds true for the valley-fill aquifer, though it is unsaturated in much of the western area. This Type 2 boundary is essentially an extension of the Type 2 boundary formed by the upper clastic aquitard, but in the area between Jackass Flats and Frenchman Flat/Mercury Valley, the boundary is formed by the volcanic aquitard. The hydraulic properties of the volcanic aquitard are discussed in the previous section on the Type 2 boundary between the lower carbonate aquifer and the volcanic and valley-fill aquifers.

The area from Lookout Peak south past Skull Mountain has numerous outcrops of the Wahmonie and Salyer Formations, and other members of the volcanic aquitard (Figure 16). South from Skull Mountain across Rock Valley, another aquitard member (the Rocks of Pavits Spring) crops out or occurs just below the thin alluvial cover. South of the NTS boundary, but still within the CRA, exposures of Cambrian rocks truncate the Tertiary units. Hydraulic head data neither support nor contradict this boundary. There is a large gap in hydrologic data in this area, and the few head values that are available are not markedly different across the boundary. 
In addition to the major flow boundary in the volcanic and valley-fill aquifers between the east and west sides of the NTS, the Cenozoic aquifer system are also separated from valley to valley on the east side of the site and from the caldera areas southward on the west side of the site (boundary 4 on Figure 9). Thus, the Volcanic and Valley-fill aquifers in Yucca Flat are hydrologically isolated from the same units in Frenchman Flat, which in turn are isolated from those in Mercury Valley. The separation is caused by both the volcanic aquitard, the upper clastic aquitard, and the lower clastic aquitard. On the western side, the volcanic aquitard isolates the Silent Canyon-Timber Mountain Caldera areas from Jackass Flats on the south.

Winograd and Thordarson (1975) conclude that groundwater in the Cenozoic aquifer system probably cannot leave Yucca Flat without moving through the volcanic aquitard to the lower carbonate aquifer. Only one narrow strip of Cenozoic rocks connects Yucca and Frenchman flats,

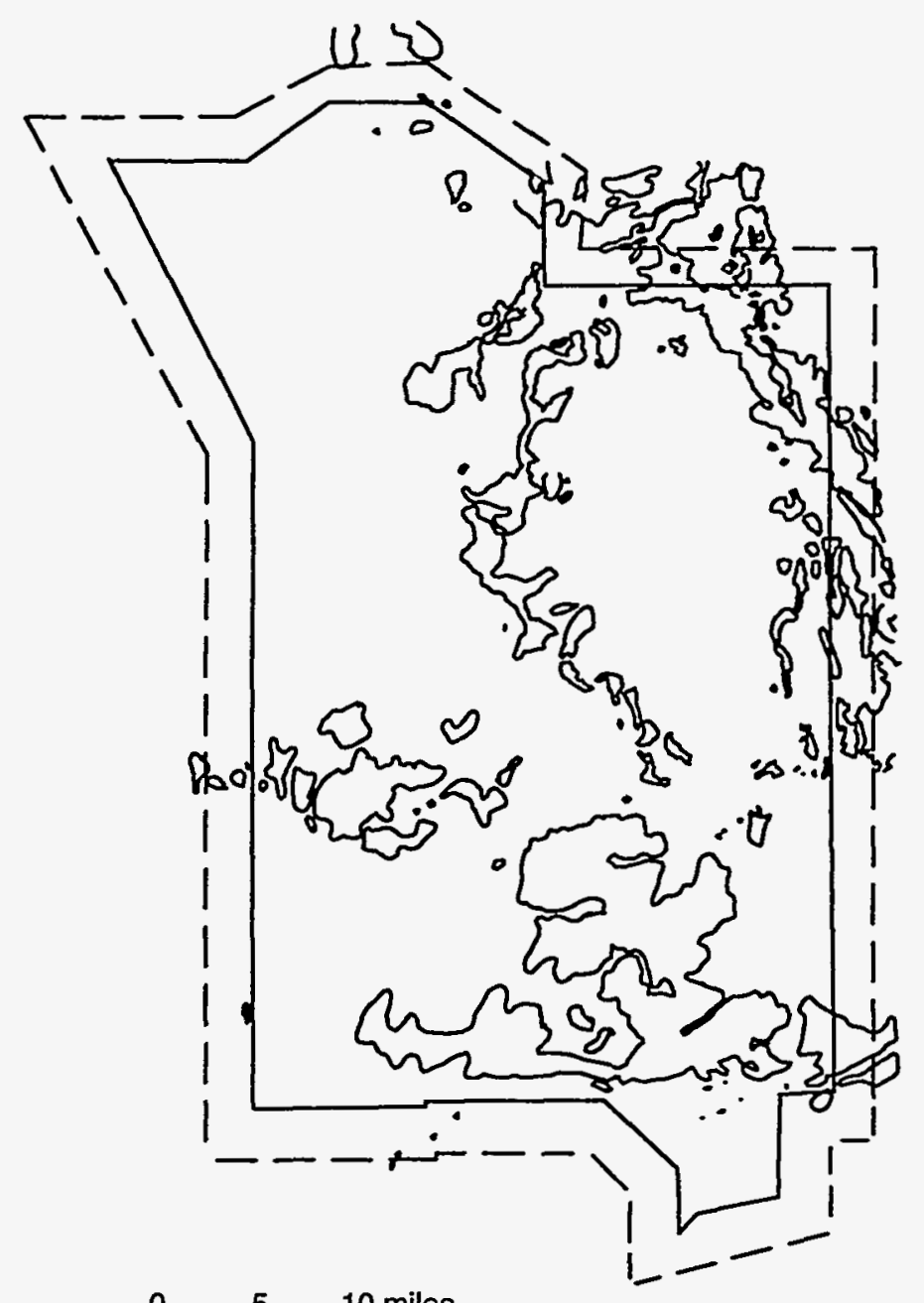

The distribution of the volcanic aquitard was taken from outcrops of aquitard units on U.S. Geological Survey Geologic Quadrangle maps (and three maps in the Miscellaneous Investigation Series). The aquitard comprises all tufts and associated sedimentary rocks older than the Paintbrush Tutf. Though a wide variety of rock types is included in this group. a common feature is a matrix of zeolite or clay minerals. Winograd and Thordarson densely welded tuff of the Grouse Canyon Member of the Indian Trail Formation from the aquitard because of its relatively high pemeability. The bedded tuff was not difterentiated on the geologic maps; therefore, the entire Grouse Canyon Member is assigned to the aquitard for the purpose of this map. Femald (1979) also included the entire Grouse Canyon in his study of the aquitard in Yucca Flat.

The geologic units mapped are:

Wahmonie Formation

Salyer Formation

Indian Trail Formation (Belted Range Tufis):

- Grouse Canyon Member

- Tub Spring Member

-Tunnel Beds

Calico Hitls- inyolite flows and tutfaceous beds

Tutf of Crater Flat

Rocks of Pavits Spring

Horse Spring Formation

The size of the final map required the loss of some detail in exact outcrop boundaries. Most large solid areas of aquitard outcrop on the figure are actually cut by small outcrops of Quatemary alluvial deposits or other units. For precise boundaries, please reter to the quadrangle maps listed below. interpretation was sometimes neces. sary as units occasionally changed dentification across quadrangle boundaries. Uncertainty is highest for the Paiule Ridge Quadrangle (east edge of Yucca Flai) as the identhed as salyer Fornation and Pavis Spring on the southerly adjacant Plunion Valley Quadrangle rere bentifed in the Paitio Roge Quadrangle as und vide miocens and Procens crops crossing the quadrangle boundary can be positively associated with aquitard units.

The sources from which the aquitard distribution was do rived are given in a separate reference section at the end of the report.

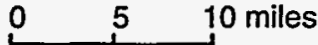

Figure 16. Outcrops of the volcanic aquitard. 
and significant flow through this strip is considered unlikely because the strip is made up of rocks of the volcanic aquitard with low transmissivities and a small cross-sectional area. If some flow does occur through this strip, it will then enter the lower carbonate aquifer which borders the strip in Frenchman Flat. Water levels in Cenozoic rocks in Yucca Flat also indicate a northerly, rather than southerly, gradient. Winograd and Thordarson (1975) believe the similarity in Cenozoic water levels in the two basins is best explained by a common sink (the lower carbonate aquifer).

The situation in Frenchman Flat is similar to that for Yucca Flat. The Valley-Fill Aquifer is enclosed on all sides by older rocks and the Volcanic Aquifer is probably surrounded and underlain by the volcanic aquitard. Any water leaving Frenchman Flat does so by either lateral flow through the aquitard or vertical flow through the aquitard to the lower carbonate aquifer. Winograd and Thordarson (1975) believe that groundwater exits the Cenozoic aquifer system by downward leakage into the carbonates.

Outcrops of the volcanic aquitard also occur on the west side of the NTS, north of Jackass Flats along the Calico Hills and Shoshone and Yucca mountains. These outcrops probably isolate the volcanic aquifer system on Pahute Mesa and in the Timber Mountain Caldera area from the Cenozoic aquifer system in Jackass Flats.

\section{EVALUATION OF CLASSIFICATION FACTORS}

In addition to general hydrogeologic information, specific data regarding water use, demographics, and environmental features are needed to assign a class to each subdivision within the CRA. In the case of the NTS, the possibility of Class I groundwater must be evaluated, requiring specific data on ecologically vital areas, groundwater supply wells, populations served by CRA groundwater, replaceability of the population's drinking water, and vulnerability of aquifers to pollution. These features are discussed below.

\section{Ecologically Vital Areas}

A groundwater is given the highest level of protection (Class I) if it is ecologically vital. Groundwater is considered ecologically vital if it supplies a sensitive ecological system located in a groundwater discharge area that supports a unique habitat. A unique habitat is defined to include habitats for listed or proposed endangered or threatened species, as well as certain types of federally managed and protected lands (e.g., wilderness areas and wildlife refuges). To be ecologically vital, a groundwater must discharge to the unique habitat, as usually evidenced by features such as springs, streams, and wetlands. Thus, potentially vital areas can be identified by first locating groundwater discharge points, then evaluating the presence of unique habitats in these areas. In addition, federal lands within the CRA that are managed for ecological values must be identified and their relationship with the hydrogeologic system evaluated.

\section{Groundwater Discharge Areas}

The discharge areas for the major groundwater flow systems at the NTS are located outside the CRA. Discharge for groundwater in the Ash Meadows groundwater subbasin (eastern half of the 
CRA) occurs primarily in the east-central Amargosa Desert via springs and evapotranspiration in Ash Meadows. Groundwater across most of the western part of the CRA, in the Alkali Flat-Furnace Creek Ranch groundwater subbasin, discharges by evapotranspiration in the far southern Amargosa Desert and in Death Valley. Groundwater beneath Pahute Mesa in the northwestern corner of the site probably discharges at springs in Oasis Valley. Some groundwater in all of these systems probably flows past the major discharge points to ultimately discharge in Death Valley. Sensitive ecological systems occur in many of these discharge areas (e.g., Devil's Hole in Ash Meadows is home to the endangered Devil's Hole pupfish), but because the NTS CRA does not overlap any of these major discharge zones, the ecosystems in these areas do not impact the classification process.

Within the CRA, discharge occurs locally at perched springs. The eight most productive springs are shown on Figure 17. The perched water apparently discharges from the volcanic aquitard. The perched groundwater mounds are believed to develop within the aquitards because drainage of recharge to underlying aquifers is retarded (Winograd and Thordarson, 1975). Most of

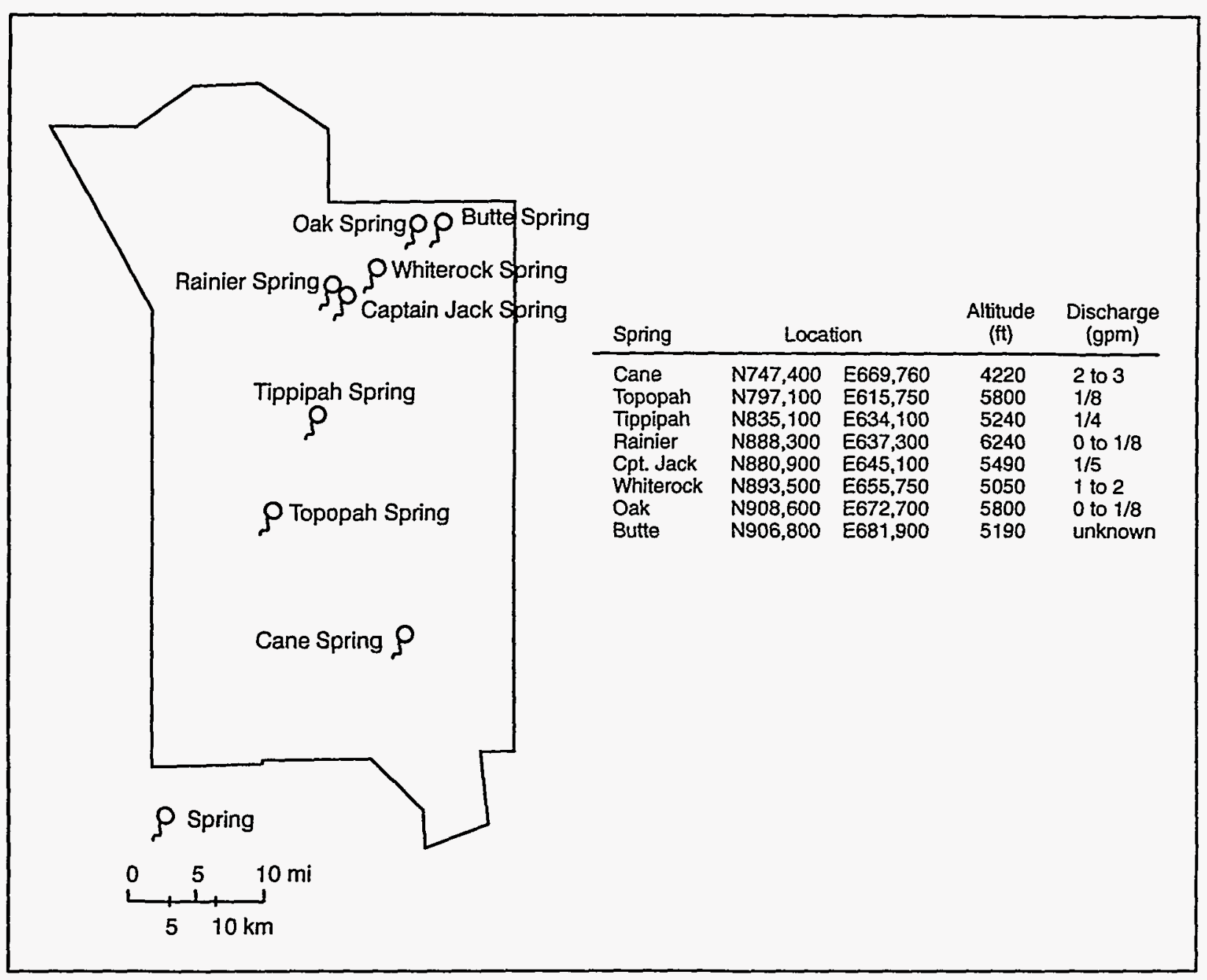

Figure 17. Location of some springs in the NTS CRA (from Moore, 1961). 
the springs are located along the northern and western margin of Yucca Flat, with one on the western edge of Frenchman Flat and one on the northern edge of Jackass Flats. Joints control the flow of Cane, Whiterock, and Oak springs. Whiterock and Cane springs are the only springs with discharge rates greater than one gpm (Moore, 1961). The other springs have maximum discharge rates of less than $1 / 3 \mathrm{gpm}$. Some of the springs have been observed to be dry at times, with flow strongly regulated by rainfall. Most of the springs have persisted for many years, with records back to 1907 (Ball, 1907), and have been used for watering stock.

The playas in Yucca and Frenchman flats receive discharge from intermittent streams and contain temporary lakes after heavy rainfalls. Despite evaporation of rainwater, the playas and valley bottoms are not discharge zones for groundwater in the CRA. Instead, these areas behave hydrologically as recharge areas to saturated zones in the valley-fill and volcanic aquifers. The great depth to the water table beneath the playas precludes interpreting them as evaporative discharge points for groundwater. The limited data on the vertical distribution of head indicates that flow is directed downward in Yucca and Frenchman flats, with the lower carbonate aquifer acting as a regional drain.

\section{Unique Habitats}

The U.S. Fish and Wildlife Service evaluated the presence of endangered and threatened species on and adjacent to the NTS and identified two listed species, no proposed species, and a number of candidate species that may occur in the CRA (Table 3). Of the two identified, neither the endangered peregrine falcon nor threatened desert tortoise are dependent on the springs found in the CRA.

The peregrine falcon was not mentioned in the records of a 1963 publication describing "The Birds of the Nevada Test Site" (Hayward et al., 1963), but a 1976 survey of NTS ecology (O'Farrell and Emery, 1976) noted that there had been a few sightings over Yucca Flat. Because the species was observed so rarely at the NTS over a 25-yearspan, the authors assume that the reported sightings were transient birds. Similarly, a 1990 bird list for the NTS (Greger, pers. comm., 1990) only included the peregrine falcon based on distribution maps (rather than sightings) and notes that it probably does not breed on the NTS. Though falcons may move through on migration, the NTS springs do not appear to be a crucial element of their habitat because some of their water needs are filled by the prey they consume.

The desert tortoise obtains moisture from its diet through eating various types of vegetation. Adult desert tortoises have been known to survive for more than a year without access to free water of any kind (Fish and Wildlife Service, 1994). Though they will drink spring water when given the opportunity, the tortoise do not live exclusively in the vicinity of the springs.

No threatened or endangered species were noted near the NTS springs during the 1976 ecological study by O'Farrell and Emery (1976). The only fish found at the NTS are goldfish that have been unofficially introduced into ponds associated with wells. The springs do provide a habitat for transient waterfowl and shorebirds, and large concentrations of small land birds will congregate 
in the evening to feed and drink (Hayward et al., 1963) at the springs, well ponds, and temporary lakes in Yucca and Frenchman flats. Burros and horses have been sighted rarely near Cane, Topopah, and Captain Jack springs. Thus, though providing an important source of water, the springs are not "unique habitats" as defined by the classification guidance document (U.S. EPA, 1988).

TABLE 3. Endangered and Threatened and Candidate Species that May Occur on and Adjacent to the Nevada Test Site (U.S. Fish and Wildlife Service File No. 1-5-94-SP-258, Carson City, Nevada).

\begin{tabular}{|c|c|}
\hline \multicolumn{2}{|c|}{ Listed Species } \\
\hline $\begin{array}{l}\text { Bird } \\
\text { E American peregrine falcon } \\
\text { Reptile }\end{array}$ & Falco peregrinus anatum \\
\hline $\begin{array}{lll}\text { (E) Endangered } & \text { (T) Threatened }\end{array}$ & \\
\hline
\end{tabular}

Candidate Species

Mammals

2 spotted bat

2 pygmy rabbit

Birds

2 loggerhead shrike

2 black tern

2 western least bittern

2 ferruginous hawk

2 western snowy plover

2 white-faced ibis

Reptile

2 chuckwalla

Plants

2 white bear desert poppy

1 Beatley milk-vetch

2 Eastwood's milkweed

2 black wooly-pod

2 Cane Spring evening primrose

2 sanicle biscuitroot

2 Pahute green gentian

2 Kingston bedstraw

2 white margined penstemon

2 Amargosa penstemon

2 Pahute Mesa beardtongue

2 Beatley phacelia

2 curve-podded Mojave milk-vetch

\author{
Euderma maculatum \\ Brachylagus idahoensis \\ Lanius ludovicianus \\ Chlidonias niger \\ Ixobrychus exilis hesperis \\ Buteo regalis \\ Charadrius alexandrinus nivosus \\ Plegadis chihi
}

Sauromalus obesus

Arctomecon merriamii

Astragalus beatleyae

Astragalus eastwoodiana

Astragalus funereus

Camissonia megalantha

Cymopterus ripleyi var saniculoides

Frasera pahutensis

Galium hilendiae ssp. kinstonense

Penstemon albomarginatus

Penstemon fruticiformis ssp. amargosae

Penstemon pahutensis

Phacelia beatleyae

Astragalus mohavensis var hemigyrus

1 - Category 1: Taxa for which the Fish and Wildlife Service has sufficient biological information to support a proposal to list as endangered or threatened.

2-Category 2: Taxa for which existing information indicated may warrant listing, but for which substantial biological information to support a proposed rule is lacking. 


\section{Federally Managed Ecological Areas}

The eastern boundary of the NTS CRA overlaps the largest national wildlife refuge in the contiguous United States, the Desert National Wildlife Range. The refuge was established in 1936 and covers 1.5 million acres. The portion of the refuge included in the CRA is jointly used by Nellis Air Force Base as a bombing and gunnery range and the U.S. Fish and Wildlife Service as a refuge. The most important objective of the refuge is perpetuating the desert bighorn sheep and its habitat. Dependable, year-round water sources are vital for the sheep's success. Most important are the mountain springs that occur at relatively high elevations, generally greater than $5,000 \mathrm{ft}$ (Dave Brown, Project Leader, Las Vegas Office of the U.S. Fish and Wildlife Service, personal communication on 12 October, 1988).

Outcrops and near-surface occurrences of the lower clastic aquitard in the northeastern part and northeast of the CRA (along the Halfpint, Papoose, and Groom ranges) act as an effective hydraulic barrier between the NTS and the northern part of the refuge. Steep hydraulic gradients and large differences in water levels across the aquitard attest to the lack of hydraulic communication (Figure 11). Groundwater data from the refuge are very sparse. However, all indications are that south of the aquitard, flow in the lower carbonate aquifer is westward, from the refuge toward the NTS. The hydrologic situation appears to be more complex near U.S. Highway 95, where hydraulic barriers associated with the Las Vegas Valley Shear Zone and the lower clastic aquitard may cause northward groundwater movement, which then joins the regional westward flow (Winograd and Thordarson, 1975).

Despite the lack of data, it can be confidently determined that groundwater within the CRA does not discharge to the springs at the Wildlife Range that are vital to the bighorn sheep. Most important to this conclusion is the fact that the springs are located above $4,000 \mathrm{ft}$ in elevation (most are above 5,000 ft), while potentiometric levels for groundwater within the eastern part of the CRA are less than 3,000 ft. It should also be noted that none of the Desert National Wildlife Range springs actually occur in the CRA, with most being located 10 to 30 miles east of the NTS boundary.

\section{Summary}

None of the groundwater occurring within the CRA is considered to be ecologically vital. Groundwater discharge within the CRA is limited to eight springs discharging from groundwater perched in the volcanic aquitard. No listed or proposed threatened or endangered species are found at these springs. The peregrine falcon (endangered) and desert tortoise (threatened) are found within the CRA, but their habitats are not exclusively at the springs. The Desert National Wildlife Range overlaps the eastern portion of the CRA, but groundwater flow is directed from the Range toward the NTS. The much higher altitude of springs on the Wildlife Range, as compared with groundwater levels at the NTS, precludes any foreseeable discharge of CRA groundwater to the environmentally sensitive springs at the Wildlife Range. Additional unique habitats are found in groundwater discharge areas downgradient from the NTS, but they occur well outside the CRA boundary and thus are beyond the distance contaminants are expected by the EPA (1988) to move in problem concentrations. 


\section{Drinking Water Wells in the Classification Review Area}

Groundwater is the only local source of drinking water in the NTS area. Drinking water wells are found on the site itself and in the southwest part of the CRA at the community of Amargosa Valley (formerly Lathrop Wells).

\section{Wells Within the NTS}

Drinking water at the NTS is supplied by 11 wells that are divided into five supply systems (Figure 18 and Table 4). In addition, commercially bottled drinking water is brought to the site from Las Vegas. Construction and fire-control water are supplied by other wells (also shown on Figure 18) and there are a number of old supply wells that are now out of service and are not included in the following discussion because there are no plans to resume using them.

The Mercury system is supplied by Army Well \#1, 5B and 5C. Army Well \#1 is located very close to the NTS boundary, southwest of Mercury. The well produces from the lower carbonate aquifer and yields relatively hard water which is softened prior to use. Wells 5B and 5C are located in Frenchman Flat and are completed in the valley-fill aquifer. They are connected to the Mercury area by an 8 -inch waterline. Wells $5 \mathrm{~B}$ and $5 \mathrm{C}$ also provide potable water to the spill test facility in Frenchman Flat.

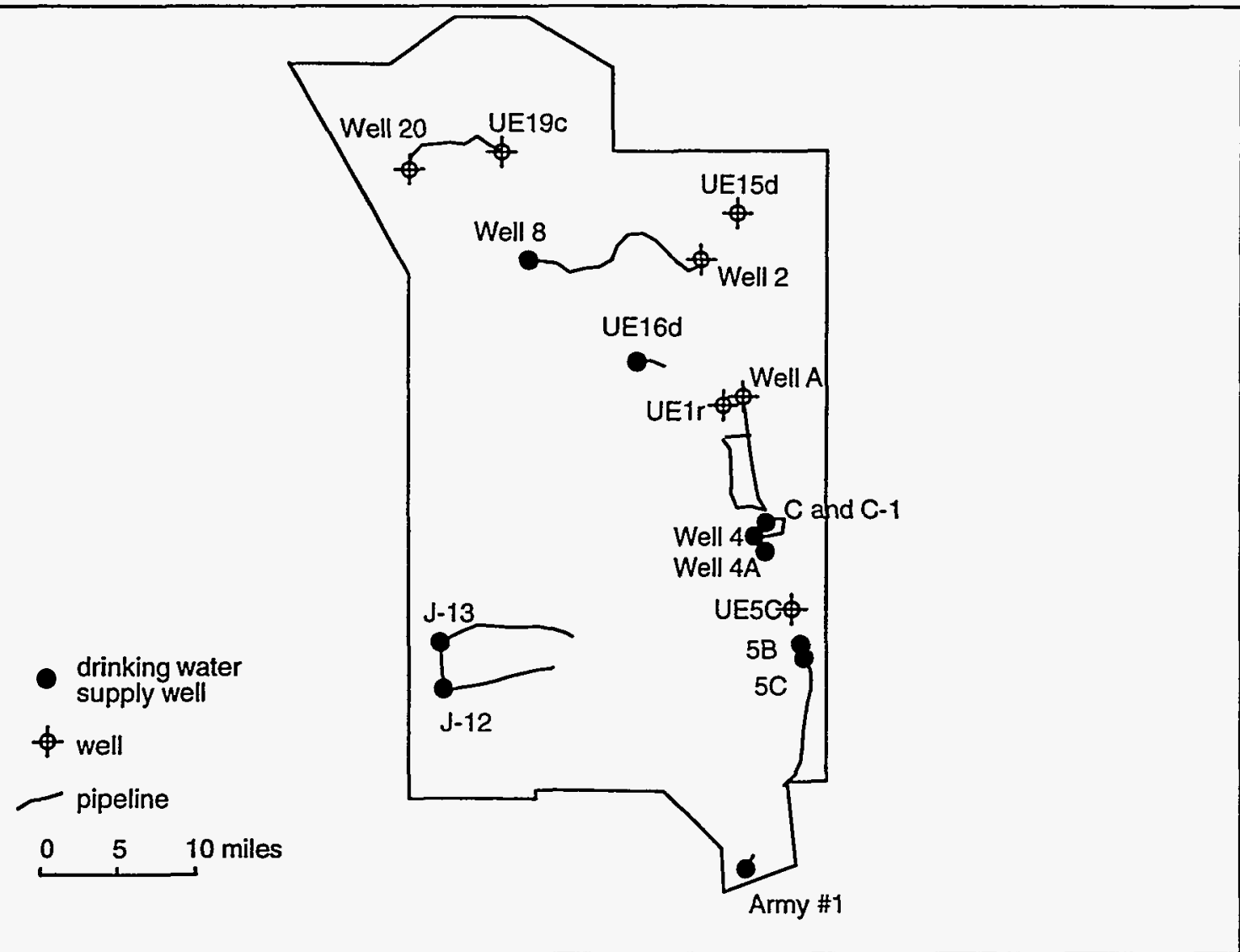

Figure 18. Water wells and pipelines on the NTS. Wells UE15d, UE1r, UE5C, and Well A are all out of service as of 1994. 
TABLE 4. Water Supply Wells on the NTS.

\begin{tabular}{|c|c|c|c|c|c|c|c|c|c|c|c|}
\hline \multirow{2}{*}{$\begin{array}{c}\text { NTS } \\
\text { area }\end{array}$} & \multirow{2}{*}{$\frac{\text { Well }}{\text { Armay 1* }}$} & \multicolumn{2}{|c|}{ Location } & \multirow{2}{*}{$\begin{array}{c}\begin{array}{c}\text { Ground } \\
\text { Everation } \\
\text { (feet) }\end{array} \\
3154\end{array}$} & \multirow{2}{*}{$\begin{array}{c}\begin{array}{c}\text { Total } \\
\text { Depth } \\
\text { (feet) }\end{array} \\
1945\end{array}$} & \multicolumn{2}{|c|}{$\begin{array}{l}\text { Depth of } \\
\text { scretred interval } \\
\text { (feet) }\end{array}$} & \multirow{2}{*}{$\begin{array}{c}\begin{array}{c}\text { Depth of } \\
\text { pump intake } \\
\text { (feet) }\end{array} \\
1152\end{array}$} & \multirow{2}{*}{$\begin{array}{c}\begin{array}{c}\text { Average } \\
\text { water depth } \\
\text { (feet) }\end{array} \\
787 \\
787\end{array}$} & \multirow{2}{*}{$\frac{\text { Aquifer }}{\text { Lower carbonate aquifer }}$} & \multirow{2}{*}{$\frac{\begin{array}{c}\text { Pump } \\
\text { capacity } \\
\text { (gpm) }\end{array}}{530}$} \\
\hline & & N670.902 & E684.772 & & & $800-1050$ & & & & & \\
\hline 5 & $5 \mathrm{~B}^{*}$ & N747.359 & E704,263 & 3092 & 900 & $685-900$ & & 753 & 684 & Alluvium & 240 \\
\hline 5 & $5 C^{*}$ & $N 742.860$ & E705,888 & 3081 & 1200 & $800-1100$ & & 1030 & 691 & Allunum & 325 \\
\hline 6 & $c^{*}$ & N790,082 & E692,061 & 3921 & 1701 & $1550-1620$ & & 1590 & 1542 & Lower carbonace aquifer & 270 \\
\hline 6 & C-1• & N790.011 & E692.132 & 3921 & 1707 & $1540-1650$ & & 1618 & 1542 & Lower carbonate aquifer & 280 \\
\hline 6 & $4^{*}$ & $N 784,999$ & $E 687,900$ & 3603 & 1479 & $942-1436$ & & 1374 & 941 & Volcancs & 650 \\
\hline 6 & $4 A^{*}$ & $N 784.350$ & E686.900 & 3606 & 1501 & not available & & 1414 & 836 & Volcanics & 700 \\
\hline 3 & $A$ & N833.000 & $E 684.000$ & 4006 & 1870 & $1615-1870$ & & 1823 & 1614 & Alluvium & 135 \\
\hline 18 & $8 *$ & N879.468 & E609.999 & 5695 & 5499 & $1068-2031$ & & 1229 & 1076 & Volcanics & 400 \\
\hline 25 & $\mathrm{~J}-12^{*}$ & N733.508 & E581,012 & 3130 & 1139 & 793-868 & & 836 & 742 & Volcanies & 815 \\
\hline 25 & 3-13* & N749.209 & E579.651 & 3318 & $3488 \ddagger$ & $996-1390$ & $2690-3312$ & 1200 & 928 & Volcanxs & 680 \\
\hline 16 & UE16d* & N844.878 & E646.567 & 4684 & 3000 & $1310-1145$ & & unknown & 755 & Upper carbonale aquifer & 194 \\
\hline 5 & UESC & $N 760.133$ & E700,997 & 3216 & 2682 & $1100-1300$ & $1682-2682$ & unknown & 824 & Alluvium and volcanics & 350 \\
\hline 15 & UEISd & N895.709 & E682,084 & 4586 & 6001 & $2800-5400$ & & 1659 & 668 & Quarzite and lower carbonate & 270 \\
\hline 1 & UEIr & $N 829.853$ & $E 677.300$ & 4042 & 4182 & $2210-4182$ & & unknown & $1628 \dagger$ & Volcanic. quartzite and limestone & unknown \\
\hline 2 & 2 & $N 880,000$ & E668.720 & 470 & 3422 & $2700-2950$ & $3164-3412$ & 2814 & 2055 & Lower carbonate aqufer & 165 \\
\hline 19 & UEIgc & N917.000 & E601,027 & 7033 & 8489 & $2421-8489$ & & unkrown & 2337 & Volcanics & 395 \\
\hline 20 & Well 20 & N910.582 & E569.090 & 6468 & 3268 & $3035-2271$ & & $2980-3048$ & 2033 & Volcanics & 380 \\
\hline
\end{tabular}

†plugged to 2130

tconfined

References for well tables:

Clanssen, 1973: Dinwiddie and Weir. 1979: F and S. 1987: F and S. 1988: Giampaoli-Bugo. 1988: Moore et al.. 1963: Thordarson and Robinson. 1971: Witherill, 1986: Young. 1972 *drinking water supply well

The southern part of Yucca Flat currently uses wells $\mathrm{C}, \mathrm{C}-1,4$ and $4 \mathrm{~A}$. Wells $\mathrm{C}$ and $\mathrm{C}-1$ are located next to each other in the southern end of the valley. Wells 4 and $4 \mathrm{~A}$ are actually located in the Frenchman Flat drainage area, though a pipeline connects it to the Yucca Flat system. Water from $\mathrm{C}$ and $\mathrm{C}-1$ comes from the lower carbonate aquifer and is softened prior to use. Wells 4 and $4 \mathrm{~A}$ are completed in the tuffs of the volcanic aquifer and also supply water to the Device Assembly Facility, south of Yucca Flat.

Well UE16d supplies potable water to Area 1 in mid-Yucca Flat and also provides construction water.

Area 12 Camp receives drinking water from Well 8, located south of Pahute Mesa and west of the camp. Well 8 is completed in tuffs and lavas of the volcanic aquifer and is considered to produce the highest quality water at the NTS (Witherill, 1986). Water from Well 8 also supplies the drinking water needs at Area 2 Camp in north Yucca Flat. Areas 19 and 20 depended on trucked water for potable supplies. Though not confirmed, it is probable that Well 8 is the source for most of the potable water used in those areas. Commercial drinking water delivered from Las Vegas is also used in Areas 19 and 20. The recent closure of Area 12 Camp and reduction of testing activities have relocated most of the people that previously relied on Well 8 for water, but potable water is still available in those areas for workers passing through.

The former NRDS in Area 25 and current site characterization activities in connection with the proposed Yucca Mountain high-level waste repository are supplied with drinking water by Wells $\mathrm{J}-12$ and $\mathrm{J}-13$. The wells are located in Fortymile Wash and are completed in the volcanic aquifer. 
In summary, drinking water wells in the eastern NTS (in the Ash Meadows groundwater subbasin) withdraw water from the lower carbonate aquifer, and the Cenozoic aquifer system. The western NTS (Alkali Flat-Furnace Creek Ranch groundwater subbasin) derives drinking water only from the Cenozoic aquifer system.

\section{Wells Outside the NTS}

In the classification guidance document, EPA states that a detailed inventory of private residential wells is not necessary for groundwater classification (U.S. EPA, 1988, p. 4-2). A well inventory has not been performed for this study, but a survey was published in 1971 for the area within 100 miles of a point on Pahute Mesa at the NTS (Thordarson and Robinson, 1971). The only public wells within the two-mile NTS CRA identified in the survey are located in and near the community of Amargosa Valley, in the area formerly known as Lathrop Wells. A well inventory reported as part of the classification of Yucca Mountain groundwater also includes the Amargosa Valley area (Giampaoli-Buqo, 1988). Data from Thordarson and Robinson (1971) and Giampaoli-Buqo (1988) have been combined to produce Table 5, while the more current Giamapoli-Buqo (1988) data were used to prepare Figure 19.

TABLE 5. Water Supply Wells Located off the NTS but within the CRA.

\begin{tabular}{|c|c|c|c|c|c|c|c|c|c|c|}
\hline \multicolumn{4}{|c|}{ Giampaoli-Buqo (1988) } & \multicolumn{7}{|c|}{ Thordarson and Robinson (1971) } \\
\hline $\begin{array}{c}\text { SAIC } \\
\text { I.D. }\end{array}$ & Owner & $\begin{array}{c}\text { Annual } \\
\text { Duty } \\
\text { acre ft/yr }\end{array}$ & Use & Location & $\begin{array}{l}\text { Depth } \\
\text { ff }\end{array}$ & $\begin{array}{c}\text { Water } \\
\text { Level } \\
\mathrm{ft}\end{array}$ & Lithology & Use & $\begin{array}{c}\text { Year } \\
\text { Drilled }\end{array}$ & Yield \\
\hline 39410 & private & 320 & irrigation & T15SR49E12da & & & & & & \\
\hline 40247 & private & 320 & irrigation & T15SR50E8bd & 442 & 229 & alluvium & inrigation & 1958 & \\
\hline 17385 & private & 118.75 & irrigation & T15SR49E27db & 487 & 256 & alluvium & irrigation & 1958 & $800 \mathrm{gpm}$ \\
\hline 17835 & private & 0 & no data & T15SR49E22dc & 570 & 291 & alluvium & irrigation & 1954 & $300 \mathrm{gpm}$ \\
\hline 17591 & private & 0 & no data & T15SR49E22an & & & & & & \\
\hline 26673 & private & 1.0 & quasimunicipal & T15SR49E24ba & & & & & & \\
\hline 18528 & private & 38.7 & commercial & TISSR50E18c & $\begin{array}{l}505 \\
507\end{array}$ & $\begin{array}{l}366 \\
359\end{array}$ & alluvium & public supply & 1955 & \\
\hline 21593 & $\begin{array}{l}\text { State } \\
\text { of } N V\end{array}$ & 16.14 & domestic & \begin{tabular}{|l} 
TI5SR50E18c \\
T15SR49E13 \\
T15SR49E13dd \\
\end{tabular} & $\begin{array}{l}360 \\
410 \\
482 \\
\end{array}$ & $\begin{array}{l}339 \\
380 \\
350 \\
\end{array}$ & alluvium & $\begin{array}{l}\text { public supply } \\
\text { domestic supply } \\
\text { public supply }\end{array}$ & $\begin{array}{l}1950 \\
1965 \\
\end{array}$ & \\
\hline
\end{tabular}

The combined well surveys suggest that three to six wells serve drinking water needs in the part of Amargosa Valley located within two miles of the NTS. All of these wells are completed in the valley-fill aquifer and are generally 400 to $500 \mathrm{ft}$ deep.

\section{Population Inventory}

One of the deciding criteria for determining whether a water is Class I or Class II is the size of the population served by water-supply wells within the CRA. A "substantial population" is generally defined by EPA as being at least 500 people. The only population group located within the CRA is part of the rural community of Amargosa Valley (U.S. DOE, 1986) and still indicated 


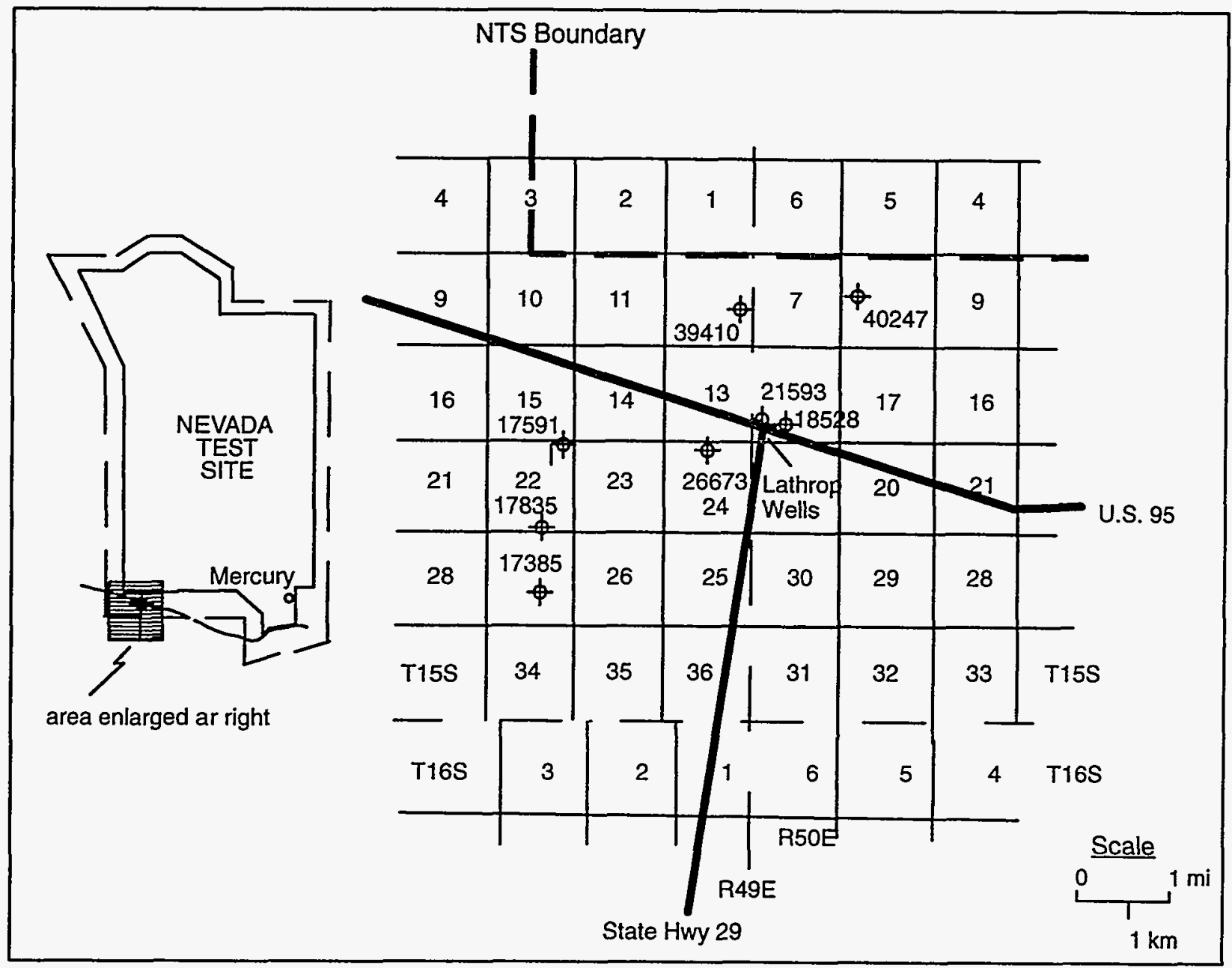

Figure 19. Water wells in the Lathrop Wells/Amargosa Valley area. Modified from Giampaoli-Buqo (1988).

as such on many maps. To prevent confusion with the other parts of Amargosa Valley, the town of Amargosa Valley will be referred to by its old name (Lathrop Wells) in the following discussion. Lathrop Wells contains three population concentrations: the townsite of Lathrop Wells, Amargosa Farm, and the American Borate housing complex. Lathrop Wells is located at the intersection of U.S. Highway 95 and State Highway 29. The latter two areas are south of the CRA and their supply wells are also south of the area. The population of Lathrop Wells in 1984 was reported as 45 (Smith and Coogan, 1984), whereas a 1982 estimate was 65 (MTTRE, 1984). 1990 Census data identified 37 people at most residing within the CRA, but south of the NTS (Figure 20), assuming all the population within each census block partially intercepted by the CRA actually lived within the CRA.

The population served by supply wells within the NTS boundary is much more difficult to determine. The census block containing the NTS and Nellis Air Force Range (Figure 21) identified no residences in that area; rather, all the population was located within group quarters $(1,016$ for the entire block, 885 in non-military group quarters). Most of the NTS population consists of workers 


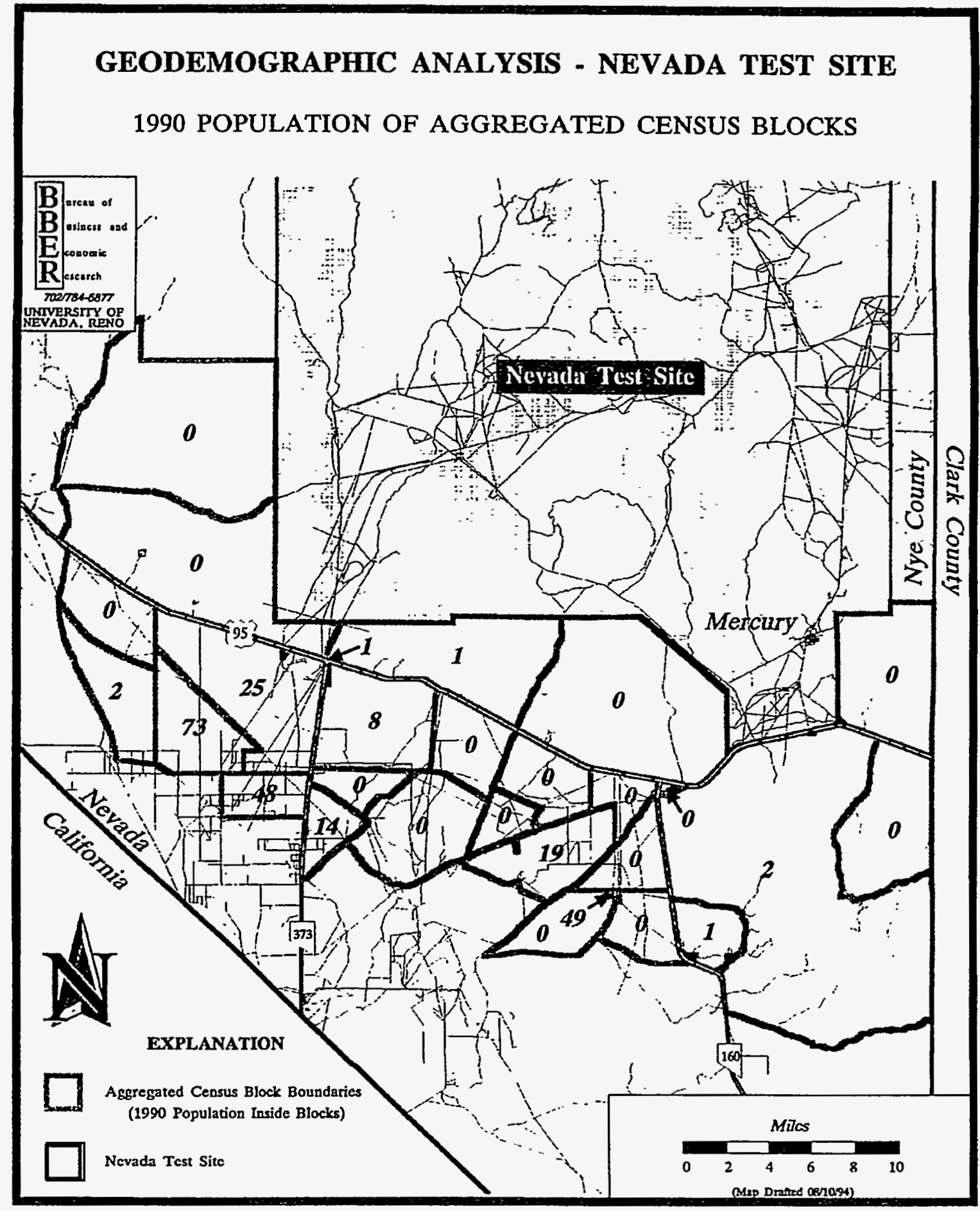

Figure 20. Demographic analysis for the area south and west of the NTS, identifying 37 people residing in census blocks intercepted by the CRA. Though the resolution of the data does not allow a determination as to whether the people actually reside within the CRA, it was assumed that the people do live within the two-mile CRA boundary for the population analysis. Data are from the 1990 Census, compiled by the Bureau of Business and Economic Research at the University of Nevada, Reno. 


\section{GEODEMOGRAPHIC ANALYSIS - NEVADA TEST SITE}

\section{US CENSUS BLOCK GROUP 9805.006}

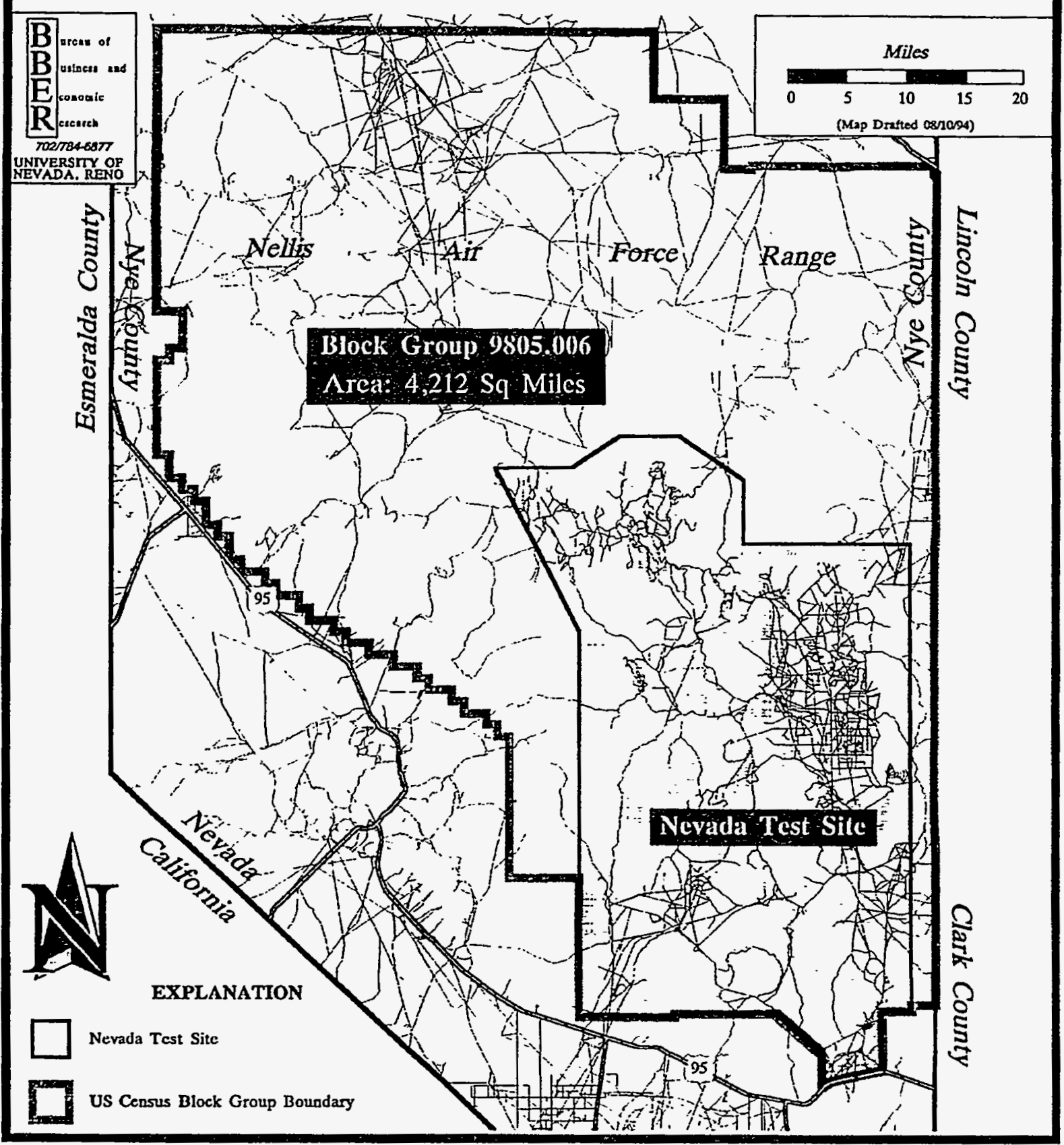

Figure 21. Location of the census block including the NTS and Nellis Air Force Range. The only population identified within the block is 1,016 people located in "group quarters." 885 of these are in non-military quarters. Data are from the 1990 Census, compiled by the Bureau of Business and Economic Research at the University of Nevada, Reno. 
who do not reside at the site. In 1984, over 83 percent of the NTS workers resided in Clark County (within the Las Vegas metropolitan area), with most of the remainder living in outlying areas (U.S. DOE, 1986). Though Mercury was reported as having a population of 300 (MTTRE, 1984), and over four percent of the NTS employees gave a zip code at Mercury as their residence, DOE reports that there are no permanent residents there (U.S. DOE, 1986; p.5-68). Mercury is the only area on the NTS that regularly has workers staying overnight. Current estimates by the contractor in charge of Mercury housing put the number of stable room reservations (those kept through the weekend) at close to 200 (though not all of the rooms are necessarily occupied), while occupancy during the week can jump to between 450 and 700 people (M. Kistler, pers. comm., 1994).

The total NTS worker population in April 1994 was estimated as 2,799. Of these, 1,422 people were stationed at Mercury, with the rest working in the forward areas. Some of the non-Mercury personnel are permanently stationed at a particular forward location. Others are transient, located wherever DOE is conducting activities, and thus do not consistently drink from the same well. Based on worker numbers and locations (R. Pearl, pers. comm., 1994), the population served by each well has been estimated (Table 6).

TABLE 6. NTS Population Breakdown by Wells and Hydrogeologic Subdivisions.

\begin{tabular}{|c|c|c|c|c|c|c|}
\hline & $\begin{array}{l}\text { Area } 25 \\
\text { (NRDS) }\end{array}$ & \multicolumn{2}{|c|}{ Mercury } & \multicolumn{2}{|c|}{ Yucca Flat } & $\begin{array}{c}\text { Northern } \\
\text { Areas }\end{array}$ \\
\hline Population & 242 & \multicolumn{2}{|c|}{1,135} & \multicolumn{2}{|c|}{1,422} & transient \\
\hline Supply Wells & $\mathrm{J}-12, \mathrm{~J}-13$ & Army \#1 & $5 B, 5 \mathrm{C}$ & $\mathrm{C}, \mathrm{C}-1$ & $4,4 \mathrm{~A}$ & 8 \\
\hline Population Per Subdivision & 242 & 711 & 711 & 409 & 726 & transient \\
\hline $\begin{array}{l}\text { Hydrogeologic Subdivision } \\
\text { Cenozoic aquifer - Pahute Mesa A } \\
\text { Cenozoic aquifer - Jackass Flats A } \\
\text { Cenozoic aquifer - Frenchman Fla } \\
\text { Lower carbonate aquifer - south a }\end{array}$ & $\begin{array}{l}\text { (Well 8) } \\
\text { (J-12, J-13 inc } \\
\text { Vells 5B, 5C, } 4 \\
\text { ast (Army \#1, }\end{array}$ & $\begin{array}{l}\text { ding est. } 65 \\
\text { d } 4 A \text { ) } \\
C-1)\end{array}$ & eople at La & $\begin{array}{l}\frac{\text { Populi }}{\text { tran }} \\
\text { Wells) } \\
1 \\
1\end{array}$ & & \\
\hline
\end{tabular}

The well system serving Mercury posed a problem because the supply wells (linked by pipeline to Mercury) are located in different hydrogeologic subdivisions. Wells 5B and 5C are completed in the valley-fill aquifer in Frenchman Flat, while Army Well \#1 produces from the lower carbonate aquifer southwest of Mercury. Well production figures show that most of the water for the Mercury system was supplied by wells 5B and 5C before a hiatus in 5B usage from 1989 to 1992 (Table 7). During the period from 1983 to 1988 , each well averaged the same production so that two-thirds of the Mercury supply came from Frenchman Flat. In the one year since 5B has resumed production, 5B and 5C only accounted for 46 percent of the Mercury supply. Assuming that the more recent record is the best predictor of the future, the population of Mercury is evenly split in supply between the Cenozoic aquifer system in Frenchman Flat and the lower carbonate aquifer.

The system serving Yucca Flat posed the same problem, with water provided by the lower carbonate aquifer through wells $\mathrm{C}$ and $\mathrm{C}-1$ and water supplied from the volcanic aquifer in the Frenchman Flat basin at wells 4 and 4A. Production figures (Table 7) were used to distribute the 
population among the wells. Over the last seven years, 64 percent of the water has come from Well 4 with the remainder from the $C$ wells. Though well $4 \mathrm{~A}$ has recently been added to the system, no data are available on its long-term use, so the Yucca Flat population is distributed according to the percentages given above. Well UE16d pumps water from the upper carbonate aquifer and supplies workers at Area 1 camp. No population data were available to distinguish Area 1 workers from the rest of the Yucca Flat population, so well UE16d was lumped with supply wells in the lower carbonate aquifer.

TABLE 7. Well Production Figures in Millions of Gallons Per Year.

\begin{tabular}{cccccccc}
\hline \hline Year & 5B & 5C & Army \#1 & 4 & 4A & C & C-1 \\
\hline 1983 & 30.8 & 41.0 & 65.3 & - & - & - & - \\
1984 & 50.6 & 50.3 & 71.1 & - & - & - & - \\
1985 & 61.1 & 61.2 & 53.9 & - & - & - & - \\
1986 & 67.5 & 48.4 & 42.4 & - & - & - & - \\
1987 & 50.5 & 50.3 & 34.7 & 28.2 & - & 7.2 & 22.3 \\
1988 & 57.5 & 67.8 & 53.1 & 46.7 & - & 17.4 & 24.8 \\
1989 & 0 & 35.4 & 114.4 & 19.2 & - & 31.6 & 28.1 \\
1990 & 0 & 38.4 & 126.0 & 68.2 & - & 29.7 & 23.3 \\
1991 & 0 & 28.8 & 109.9 & 70.7 & - & 27.7 & 23.8 \\
1992 & - & 61.1 & 139.4 & 84.5 & - & 14.8 & 30.3 \\
1993 & 29.8 & 63.2 & 110.2 & 75.4 & $0.2^{*}$ & 22.2 & 9.4 \\
\hline \hline
\end{tabular}

- indicates unavailable data

* pumping quantity for one day

Combining the population assigned to wells $5 \mathrm{~B}$ and $5 \mathrm{C}$ with that assigned to wells 4 and $4 \mathrm{~A}$ results in a total of 1,437 people provided with drinking water from Cenozoic aquifer system in Frenchman Flat. Adding the populations served by Army Well \#1 and wells $C$ and C-1 yields 1,120 people drinking water from the lower carbonate aquifer.

Two additional factors must be considered when evaluating the NTS population and both tend to decrease the population served. First, the vast majority of the people at the NTS are only there during working hours, so NTS supply wells are not their only source of drinking water. Rather, public supply systems outside of the CRA (primarily in Las Vegas) provide part of the water consumed. Only 200-750 people stay overnight at the NTS and none of these are permanent residents. Though CRA water supplies the 24-hour demand of this small population, these people do not remain at the site year round.

The EPA provides no guidance on how to treat a working, non-resident population, though they do state that if the population is served by other water sources, they should be accounted for proportionately (U.S. EPA, 1988). One way to do this would be to reduce the population by a factor equal to the waking time spent by the workers away from the CRA (i.e., a reduction of about 37 percent based on eight hours of sleep and 10 hours at work). 
The second factor to be addressed is the use of bottled drinking water at the NTS. A Las Vegas bottled water company delivers an average of 3,200 bottles of water to the NTS each month. The water originates in the Las Vegas area, outside the CRA. At five gallons per bottle, this amounts to 16,000 gallons of drinking water per month that should be accounted for proportionately with the water supply wells. This cannot be done simply based on the amount of water produced from the wells because the wells are used extensively for non-potable needs. Health-effects calculations generally assume that a person consumes approximately 0.53 gallons (two liters) of water per day. Using this value is conservative, since some water will be consumed at home rather than at the site. Assuming an average of 22 work days per month, 727 gallons are consumed each day which could supply 1,372 people exclusively with bottled water.

Considering the non-resident (worker) status of the NTS population, the distribution of water supplies in hydrologic subdivisions, and abundance of bottled water supplied from outside the CRA, the population relying on CRA groundwater is not considered to be substantial. Given the subjective nature of this judgement due to the NTS not conforming to the EPA guidance, a replaceability analysis for the water supply was performed as if the population were substantial.

\section{Replaceability Of Drinking Water}

As discussed above, the worker population supplied by the lower carbonate aquifer and the workers supplied by the Cenozoic aquifer system in Frenchman Flat are not considered substantial populations. Generally, once a substantial population is identified, EPA requires a determination of irreplaceability. Given the uncertainty in considering workers rather than resident populations, an analysis of the replaceability of the groundwater supply is performed below. EPA has five screening tests that are first performed, followed by a final determination.

\section{Screening Test 1: Uncommon Pipeline Distance}

Reasonable pipeline distances are used by EPA to define the area within which alternative water supplies can be considered. Though actual pipeline distances in a region can be surveyed, threshold pipeline distances based on population can be used for delineating the area within which alternative water sources may be considered (U.S. EPA, 1988). For the smallest population group (500 to 5,000 people), the uncommon pipeline distance set by EPA is 25 miles. Thus, any replacement source of water beyond 25 miles cannot be considered for the NTS. EPA allows alternative groundwater sources to be located in the same aquifer or in a nearby aquifer, if horizontally or vertically separated from the source aquifer. Given these conditions, alternative water supplies are available within the actual NTS site boundary. For example, if the Cenozoic aquifer system in Frenchman Flat were contaminated, the underlying carbonate aquifer could be pumped to replace the lost capacity. The volcanic aquifers at and near Pahute Mesa are also available to provide large quantities of good quality water; indeed, Well 8 provided drinking water for approximately 1,200 people until recent changes in activities at the NTS. Within a 25-mile boundary (Figure 22), the carbonate aquifer is available, as are aquifers in Tertiary volcanics and Quaternary valley-fill material (Rush, 1971). 


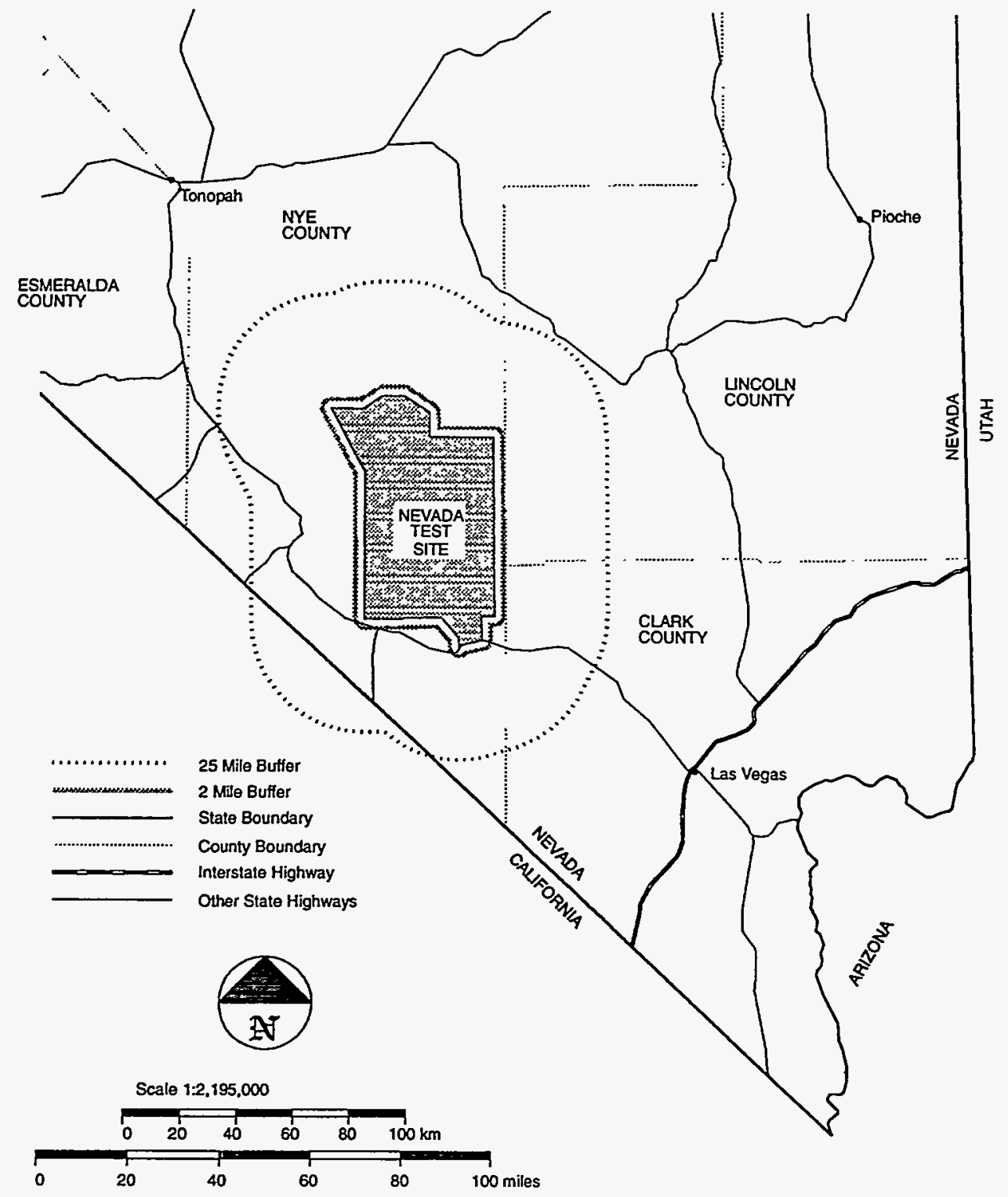

Figure 22. Map of southern Nevada showing the NTS, two-mile CRA boundary, and 25-mile "uncommon pipeline distance." Water sources within the 25 -mile buffer can be considered as potential alternative water supplies for the CRA. 


\section{Screening Test 2: Institutional Constraints}

This test identifies any legal or administrative restrictions that could preclude accessing replacement water sources. Groundwater in the State of Nevada is regulated by the State Engineer's office through a permit system. The fundamental basis for allocating groundwater is the concept of perennial yield: the renewable groundwater resource is determined and basins are generally not allocated beyond that amount. Most of the basins intercepted by the 25 -mile buffer are not currently fully allocated (Figure 23), thus there is no institutional constraint that $a$ priori limits the availability of alternative groundwater supplies.

\section{Screening Test 3: Comparable Quality}

A potential replacement water supply must have a level of water quality that is not substantially poorer than other raw drinking-water resources in the area. The regional water quality in and around the CRA is generally comparable (Eakin et al., 1963; Lyles et al., 1987) and adequate for potable needs. The lower carbonate aquifer contains $\mathrm{Ca}-\mathrm{Mg}-\mathrm{HCO}_{3}$ water and volcanic aquifers contain $\mathrm{Na}-\mathrm{K}-\mathrm{HCO}_{3}$ water. Groundwater in the alluvium can have either a carbonate or volcanic chemical signature, depending on the source of the alluvial material. Total dissolved solids contents are generally low and there are few sources of possible groundwater pollution and none that represent a widespread threat to aquifer quality.

\section{Screening Test 4: Comparable Quantity}

A replacement water must be available in a quantity that is essentially equal to the quantity supplied by the current groundwater resource. Annual usage averaged over the last seven years in the two subdivisions with possible substantial populations are 460 acre-ft supplied by the Cenozoic aquifer system in Frenchman Flat and 440 acre-ft supplied by the lower carbonate aquifer across the eastern part of the CRA. As the recharge quantities and hydraulic characteristics are generally similar for aquifers in similar materials but different basins, naturally available quantity of replacement water is considered comparable. For example, the perennial yield of the Groom Lake subsection of the Emigrant Valley hydrographic area, located east of the NTS, is 2,800 acre-ft/yr (State of Nevada, 1988).

\section{Screening Test 5: Economic Irreplaceability}

Economic irreplaceability is the most rigorous screening test, but its conditions do not apply well to the NTS. EPA has defined economic irreplaceability in terms of cost per household, a concept that does not fit with the transient worker status of water consumers at the NTS. In the test, the replacement water system cost is compared to an EPA-determined threshold value to determine whether the cost of the replacement system would impose an economically unreasonable burden on the user population. At the NTS, the possibly substantial population served is comprised entirely of workers that do not bear any economic responsibility for the water system. Given the proximity (both vertically and laterally) of alternative water sources, it is believed that replacement supplies are economically reasonable; however, if the costs were found to be prohibitive, workers could be supplied with bottled water for their potable needs. 


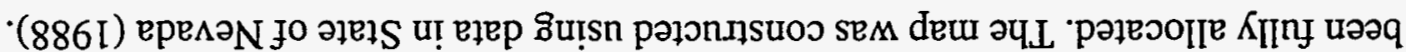

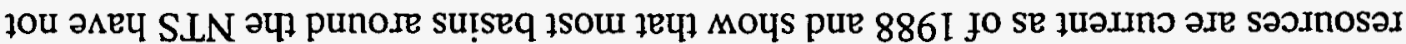

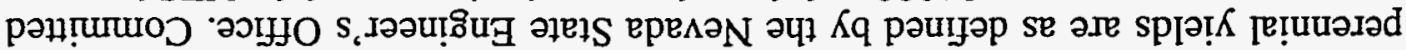

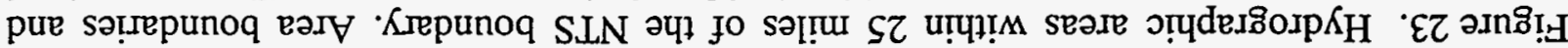

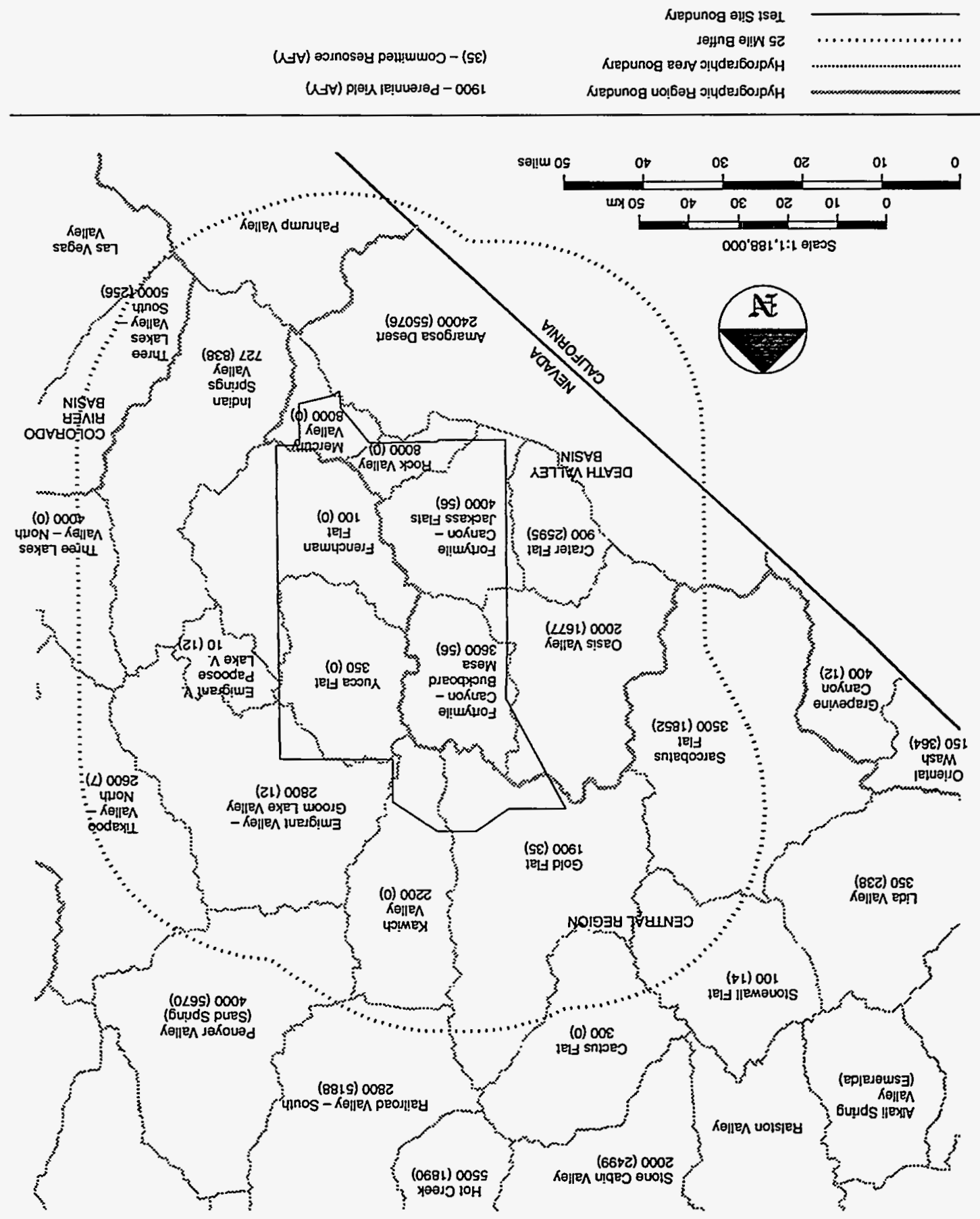




\section{Final Irreplaceability Determination}

EPA allows a final review of qualitative criteria to ensure that an irreplaceable designation is not warranted for a groundwater. The criteria to be considered are: presence of transient populations, projected trends in population size, economic conditions, water development projects, and use of unreliable transport mechanisms. The "transient population" criterion does not apply to the NTS CRA as the transient work force was considered during the population evaluation and no other transient population exists. The "unreliable transport mechanism" also does not apply as alternative water sources would be supplied by mechanisms that have the same reliability as existing wells and pipelines. Projected trends in population, economics, and water development are the most difficult to predict; however, no changes are anticipated that would result in altering the water supply to irreplaceable status.

\section{Aquifer Vulnerability}

Groundwater must be highly vulnerable to contamination for a Class I assignment, in addition to being an irreplaceable source of drinking water to a substantial population or being ecologically vital. Vulnerability is characterized by EPA as a relatively high potential for contaminants to enter and be transported within the flow system, and thus includes the leaching potential of the vadose zone and ability of the saturated flow system to move contaminants over a large area.

The EPA suggests three quantitative approaches to determining vulnerability: Multiple Factor Methods, Numerical Ranking Systems, and Integrative Methods. The numerical ranking system known as DRASTIC (Aller et al., 1987) was chosen for the NTS because EPA provides clear guidance as to the score considered indicative of a highly vulnerable setting. DRASTIC scores were computed for the Cenozoic aquifer system and the lower carbonate aquifer (Table 8) and found to be below the score of 120 suggested by EPA as indicating a highly vulnerable setting in regions where potential evapotranspiration exceeds precipitation (a score of 150 is used in wetter regions). The lower carbonate aquifer has a lower score (87) than the Cenozoic aquifer system (98) because the carbonate is confined throughout most of the area. The relatively low scores for both aquifer groups reflect the great depth to water throughout the region and small potential recharge rates. These same factors lead to a qualitative sense that groundwater in the CRA is not highly vulnerable to surface contaminants.

The issue of groundwater contamination from surface facilities has received extensive study at the Radioactive Waste Management Site in the southeastern part of the CRA. Measurements of hydraulic parameters and chemical tracers on samples collected during drilling of 10 shallow boreholes and three wells at the site indicate that net water movement is actually upward in the upper part of the vadose zone driven by high evapotranspiration (Detty et al., 1993). Chemical and isotopic tracers suggest that recharge at the RWMS has not occurred since the last glacial maximum 15,000 to 20,000 years ago (Tyler et al., 1994). Under these conditions, there is essentially no threat to groundwater quality from surface activities. The findings from Frenchman Flat are probably representative of conditions in valley floors throughout the CRA. The highland areas on the NTS are believed to have downward fluxes carrying precipitation as recharge to the water table, but these 
areas (e.g., Pahute Mesa) also have great depths to water (approximately 2,000 ft) that preclude rapid infiltration to the water table. Perched water does occur at relatively shallow depths (60 to $80 \mathrm{ft}$ ) in some locations, but is always associated with aquitards underlying ridges and thus are not part of the regional system (Winograd and Thordarson, 1975).

TABLE 8. Numerical Ranking of Aquifers using the DRASTIC System to Determine Vulnerability of Aquifers to Surface Contaminants.

\begin{tabular}{llrrr}
\hline \hline FEATURE & RANGE & WEIGHT & RATING & NUMBER \\
\hline DRASTIC Score for Cenozoic Aquifer System & & & \\
Depth to Water & $500-2,000 \mathrm{ft}$ & 5 & 1 & 5 \\
Net Recharge & $0-1$ inch/yr & 4 & 1 & 4 \\
Aquifer Media & Sand and Gravel/Basalt & 3 & 7 & 21 \\
Soil Media & thin or absent & 2 & 10 & 20 \\
Topography & widely varying & 1 & 5 & 5 \\
Impact Vadose Zone & Sand and Gravel/Igneous & 5 & 8 & 40 \\
Hydraulic Conductivity & 5-70 gpd/ft & 3 & 1 & 3 \\
Total Score & & & & 98 \\
\hline DRASTIC Score for Lower Carbonate Aquifer & 500-2,000 ft & 5 & & \\
Depth to Water & $0-1$ inch/yr & 4 & 1 & 5 \\
Net Recharge & Massive Limestone & 3 & 8 & 24 \\
Aquifer Media & thin or absent & 2 & 10 & 20 \\
Soil Media & widely varying & 1 & 5 & 5 \\
Topography & Confining layer & 5 & 1 & 5 \\
Impact Vadose Zone & 1,000 gpd/ft ${ }^{2}$ & 8 & 24 \\
Hydraulic Conductivity & & & & 87 \\
Total Score & & & \\
\hline \hline
\end{tabular}

\section{GROUNDWATER CLASSES AT THE NEVADA TEST SITE}

Using the information presented in the earlier sections, a groundwater class was assigned to each of the hydrogeologic subdivisions of the aquifers in the CRA. All of the subdivisions were classified as either IIA, current source of drinking water, or IIB, potential source of drinking water (Figure 24).

None of the groundwater at the NTS belongs to the special category of Class I. The groundwater in the CRA is not considered ecologically vital according to the classification criteria. Though groundwater in the CRA is a source of drinking water, the populations served are not considered substantial given the transient worker status of the vast majority of water consumers. In addition, the groundwater supplies are replaceable and not highly vulnerable to contamination from surface facilities. 


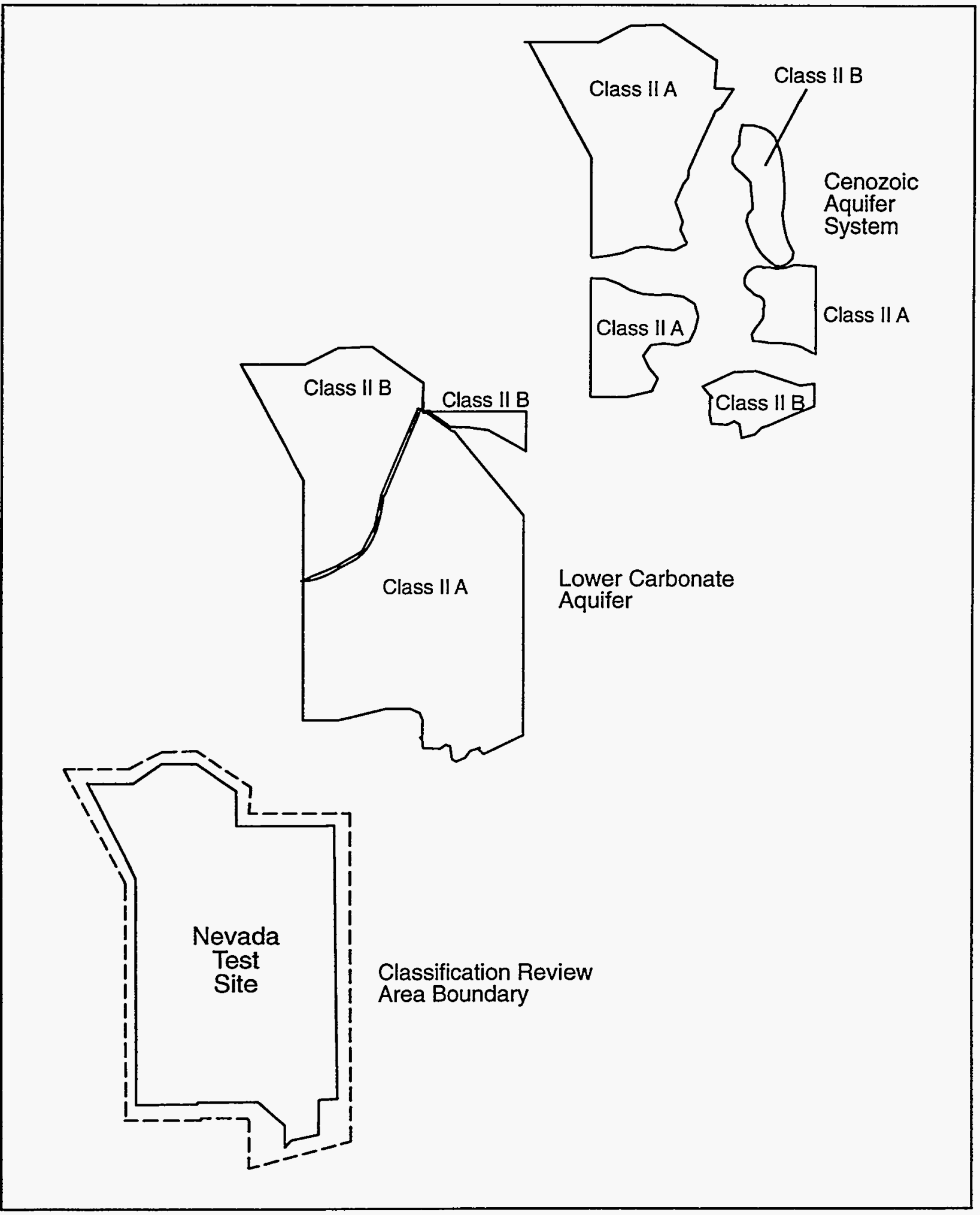

Figure 24. Classification assigned to the hydrogeologic subdivisions of the NTS CRA. The outline of the upper two maps is that of the Classification Review Area boundary, with blank areas between hydrogeologic subdivisions. 
The lower carbonate aquifer in the eastern and southern part of the CRA, the Cenozoic aquifer system in the southwestern part of the CRA, the Cenozoic aquifer system in Frenchman Flat, and the Cenozoic aquifer system on Pahute Mesa are all current sources of drinking water and thus are Class IIA. Large areas within these Class IIA units do not have wells and are far removed from any well-capture zones. However, since no hydrologic barrier could be demonstrated within the units, the entire subdivision must hold the "current source of drinking water" classification. For example, in Frenchman Flat, water wells only produce from the valley-fill aquifer, but the lack of a barrier between the valley-fill and the volcanic aquifers requires that both Cenozoic aquifer system receive a IIA classification.

The lower carbonate aquifer in the northeast and northwest parts of the CRA and the Cenozoic aquifer system in Yucca Flat and Mercury Valley are classified as IIB, potential sources of drinking water. In most of the units (particularly in the Cenozoic aquifer system of Yucca Flat), data are available that indicate the water should not be considered Class III (yields are over $150 \mathrm{gpd}$ to a well and TDS is far below $10,000 \mathrm{mg} / \mathrm{L}$ ). For the lower carbonate aquifer in the northwest part of the CRA, however, no data on aquifer properties are available and the very existence of the aquifer in that area is in doubt. The EPA recommends that "the general rule is to presume, in the absence of data, that the quality and yield of a ground-water resource is sufficient to meet the criteria for a potential source of drinking water" (U.S. EPA, 1988, p.5-5). Thus, the de facto assumption is that any water not currently being used as a drinking water source is a potential source and the burden of proof lies on justifying a lower classification.

The final issue in the classification process is the possibility of a Class III designation for water that is contaminated beyond a treatable extent. At the NTS, there has been groundwater contamination as a result of underground nuclear testing activities (Borg et al., 1976; DOE, 1988) and, in some areas, gross contamination with tritium has rendered the water non-potable and non-treatable. However, groundwater "will not be considered Class III when contamination is due to an action or in-action on the part of the facility in question" (U.S. EPA, 1988, p. 6-2). Thus, all groundwater at the NTS receives a minimum of a Class IBB designation, despite the presence of known, untreatable, groundwater contamination in some areas.

\section{REFERENCES}

Aller, L., T. Bennett, J. Lehr, R. Petty and G. Hackett, 1987. DRASTIC: A Standardized System for Evaluating Ground Water Pollution Potential Using Hydrogeologic Settings. EPA/600/2-87/035, 622p.

Ball, S.H., 1907. A Geologic Reconnaissance in Southwestern Nevada and Eastern California. U.S. Geological Survey Bulletin 308, 218p.

Barnes, H.B., F. N. Houser and F.G. Poole, 1963. Geologic Map of the Oak Spring Quadrangle, Nye County, Nevada. U.S. Geological Survey, Geologic Quadrangle Map GQ-214.

Barnes, H.B. and F.G. Poole, 1968. Regional Thrust-Fault System in Nevada Test Site and Vicinity. In Eckel, E.B. (ed.), Nevada Test Site. Geological Soc. Am. Mem. 110, p. 233-238. 
Blankennagel, R.K. and J.E. Weir, Jr., 1973. Geohydrology of the Eastern Part of Pahute Mesa, Nevada Test Site, Nye County, Nevada. U.S. Geological Survey Professional Paper 712-B, 35p.

Borg, I.Y., R. Stone, H.B. Levy and L.D. Ramspott, 1976. Information Pertinent to the Migration of Radionuclides in Ground Water at the Nevada Test Site, Part 1: Review and Analysis of Existing Information. Lawrence Livermore National Laboratory, UCRL-52078 pt.1, 216p.

Claassen, H.C., 1973. Water Quality and Physical Characteristics of Nevada Test Site Water-supply Wells, U.S. Geological Survey Report 474-158, 145p.

Claassen, H.C. and E.H. Cordes, 1975. Two-Well Recirculating Tracer Test in Fractured Carbonate Rock, Nevada. Hydrological Sciences Bulletin, Vol.20, No.3, pp. 367-382.

Detty, T.E., D.P. Hammermeister, D.O. Blout, M.J. Sully, R.L. Dodge, J. Chapman and S.W. Tyler, 1993. Water Fluxes in a Deep Arid-Region Vadose Zone. EOS Transactions American Geophysical Union, Vol. 74, No. 43, p. 297.

Dinwiddie, G.A. and J.E. Weir, Jr., 1979. Summary of Hydraulic Tests and Hydrologic Data for Holes UE16d and UE16f, Syncline Ridge Area, NTS. U.S. Geological Survey Report, USGS-1543-3, $21 \mathrm{p}$.

Eakin, T.E., G.B. Maxey, T.W. Robinson, J.C. Fredericks and O.J. Loeltz, 1951. Contributions to the Hydrology of Eastern Nevada. State of Nevada Office of the State Engineer, Water Resources Bulletin No.12, 171p.

Eakin, T.E., 1966. A regional interbasin ground-water system in the White River area, southeastern Nevada. Water Resources Research, V.2, no.2, p.251-271.

Eakin, T.E., S.L. Schoff and P. Cohen, 1963. Regional Hydrology of a Part of Southern Nevada: A Reconnaissance. U.S. Geological Survey, Trace Element Investigation TEI-833, 40p.

Fenix and Scisson, Inc., 1988. Letter Report of Hole History Information for the NTS. Personal communication from J.A. Cross to F.R. Huckabee, 10-3-88, Ref. TES-7435.

Fenix and Scisson, Inc., 1987. NTS Drilling and Mining Summary.

Fenske, P.R. and C.L. Carnahan, 1975. Water Table and Related Maps for Nevada Test Site and Central Nevada Test Area. Prepared by the Desert Research Institute for the U.S. Energy Research and Development Administration, Nevada Operations Office, NVO-1253-9, 18p.

Giampaoli-Buqo, M.C., 1988. Classification of Ground Water Beneath and Proximal to Yucca Mountain, Nye County, Nevada: Candidate Site for a Mined Geologic Disposal System. U.S. Department of Energy, Nevada Nuclear Waste Storage Investigations, 36p.

Hayward, C.L., M.L. Killpack and G.L. Richards, 1963. Birds of the Nevada Test Site. Brigham Young University Science Bulletin, Biological Series, Vol. II, No. 1, 27p. 
Lyles, B.F., R.L. Jacobson and J.W. Hess, 1987. Reconnaissance of Groundwater Quality in Southern Nevada. Desert Research Institute, Water Resources Center Publication \#41101, 83p.

Maldonado, F., 1985. Geologic Map of the Jackass Flats Area, Nye County, Nevada. U.S. Geological Survey, Miscellaneous Investigations Series Map I-1519.

Maxey, G.B. and M.D. Mifflin, 1966. Occurrence and movement of ground water in carbonate rocks of Nevada, in Moore, G.W., ed., Limestone hydrology - a symposium with discussion. National Speleological Society Bulletin, V. 28, No.3, p.141-157.

MITRE Corp., 1984. Nevada Nuclear Waste Storage Investigations Environmental Area Characterization Report. Sandia National Laboratories Report SAND83-7132, variable paging.

Moore, J.K., 1961. Records of Wells, Test Holes, and Springs in the Nevada Test Site and Surrounding Area. U.S. Geological Survey, Trace Elements Investigations Report, TEI-781, 22p.

Moore, J.E., A.C. Doyle, G.E. Walker, R.A. Young, 1963. Ground-Water Test Well 2, Nevada Test Site, Nye County Nevada. U.S. Geological Survey, Report TEI-836, 73p.

O'Farrell, T.P. and L.A. Emery, 1976. Ecology of the Nevada Test Site: A Narrative Summary and Annotated Bibliography. U.S. Energy Research and Development Administration, Nevada Operations Office, Report NVO-167, 249p.

Reynolds Electrical and Engineering Co., Inc., 1994, Site Characterization and Monitoring Data from Area 5 Pilot Wells, Nevada Test Site, Nye County, Nevada. U.S. Department of Energy Report DOE/NV/11432-74, variable paging.

Rush, F.E., 1971. Regional Ground-Water Systems in the Nevada Test Site Area, Nye, Lincoln, and Clark Counties, Nevada. State of Nevada Department of Conservation and Natural Resources, Water Resources-Reconnaissance Series Report 54, 25p.

Smith, D.D. and J.S. Coogan, 1984. Population Distribution Around the Nevada Test Site - 1984. U.S. Environmental Protection Agency, EPA-600/4-84-067.

State of Nevada, 1988. Hydrographic Basin Statistical Summary - Ground Water Basins 001-232. State of Nevada Department of Conservation and Natural Resources, Division of Water Resources and Water Planning, variable paging.

Thordarson, W. and B.P. Robinson, 1971. Wells and Springs in California and Nevada Within 100 Miles of the Point $3715^{\prime}$ N., $11625^{\prime}$ W., On the Nevada Test Site. U.S. Geological Survey, Report USGS-474-85, 175p.

Tyler, S.W., J.B. Chapman, S.H. Conrad and D. Hammermeister, 1994. Reconciliation of Soil Water Flux, Recharge, and Paleoclimate in the Southern Great Basin, Nevada-California. EOS, Transactions American Geophysical Union, Vol. 75, No. 16, p.159. 
Tyler, S.W., J.B. Chapman, S.H. Conrad and D. Hammermeister, in press. Paleoclimatic response of a deep vadose zone in southern Nevada, U.S.A. as inferred from soil water tracers. In International Atomic Energy Agency Proceedings of the First International Symposium on Tracers in Arid Zones.

U.S. Department of Energy, 1990. Announced United States Nuclear Tests, July 1945 through December 1989. DOE/NV-209 (Rev. 10), 122p.

U.S. Department of Energy, 1988. Site Characterization Plan, Yucca Mountain Site, Nevada Research and Development Area, Nevada. DOE/RW-0160, variable paging.

U.S. Department of Energy, 1986. Environmental Assessment, Yucca Mountain Site, Nevada Research and Development Area, Nevada, Vol. 1. DOE/RW-0073, variable paging.

U.S. Energy Research and Development Administration, 1977. Final Environmental Impact Statement, Nevada Test Site, Nye County, Nevada. ERDA-1551, variable paging.

U.S. Environmental Protection Agency, 1988. Guidelines for Ground-Water Classification Under the EPA Ground-Water Protection Strategy, variable paging.

U.S. Environmental Protection Agency, 1986. Guidelines for Ground-Water Classification Under the EPA Ground-Water Protection Strategy, Final Draft, 137p. +appendices.

U.S. Environmental Protection Agency, 1984. Ground-Water Protection Strategy. U.S. EPA, Office of Ground-Water Protection, 56p.

U.S. Geological Survey, 1984. A Summary of Geological Studies Through January 1, 1983, of a Potential High-Level Radioactive Waste Repository Site at Yucca Mountain, Southern Nye County, Nevada. U.S. Geological Survey Open-File Report 84-792, 103p.

Waddell, R.K., 1982. Two-Dimensional, Steady-State Model of Ground-Water Flow, Nevada Test Site and Vicinity, Nevada-California. U.S. Geological Survey, Water-Resources Investigations Report 82-4085, 71p.

Waddell, R.K., J.H. Robison and R.K. Blankennagel, 1984. Hydrology of Yucca Mountain and Vicinity, Nevada-California, Investigative Results Through Mid-1983, U.S. Geological Survey, Water-Resources Investigations Report 84-4267, 72p.

Winograd, I.J. and W. Thordarson, 1975. Hydrogeologic and Hydrochemical Framework, South-Central Great Basin, Nevada-California, with Special Reference to the Nevada Test Site. U.S. Geological Survey Professional Paper 712-C, 126p.

Witherill, V., 1986. Letter Summary of Water Use at the Nevada Test Site, Nye County, Nevada. DOE/NTSO-8450.

Young, R.A., 1972. Water Supply for the Nuclear Rocket Development Station at the U.S. Atomic Energy Commission's Nevada Test Site. U.S. Geological Survey Water-Supply Paper 1938, 19p. 


\section{REFERENCES FOR FIGURE 16 ONLY}

Barnes, H., R.L. Christiansen and F.M. Byers, Jr., 1965. Geologic Map of the Jangle Ridge Quadrangle, Nye and Lincoln Counties, Nevada. U.S. Geologic Survey Geological Survey, Geologic Quadrangle Map GQ-363.

Barnes, H., E.B. Ekren, C.L. Rodgers and D.C. Hedlund, 1982. Geologic and Tectonic Maps of the Mercury Quadrangle, Nye and Clark Counties, Nevada. U.S. Geologic Survey, Miscellaneous Investigations Series Map I-1197.

Barnes, H., F.N. Houser and F.G. Poole, 1963. Geologic Map of the Oak Spring Quadrangle, Nye County, Nevada. U.S. Geologic Survey, Geologic Quadrangle Map GQ-214.

Byers, F.M., Jr. and H. Barnes, 1967. Geologic Map of the Paiute Ridge Quadrangle, Nye and Lincoln Counties, Nevada. U.S. Geological Survey, Geologic Quadrangle Map GQ-577.

Byers, F.M., Jr., C.L. Rogers, W.J. Carr and S.J. Luft, 1966. Geologic Map of the Buckboard Mesa Quadrangle, Nye County, Nevada. U.S. Geological Survey, Geologic Quadrangle Map GQ-552.

Carr, W.J. and W.D. Quinlivan, 1966. Geologic Map of the Timber Mountain Quadrangle, Nye County, Nevada. U.S. Geological Survey, Geologic Quadrangle Map GQ-503.

Colton, R.B. and E.J. McKay, 1966. Geologic Map of the Yucca Flat Quadrangle, Nye and Lincoln Counties, Nevada. U.S. Geological Survey, Geologic Quadrangle Map GQ-582.

Colton, R.B. and D.C. Noble, 1967. Geologic Map of the Groom Mine SW Quadrangle, Nye and Lincoln Counties, Nevada. U.S. Geological Survey, Geologic Quadrangle Map GQ-719.

Ekren, E.B. and K.A. Sargent, 1965. Geologic Map of the Skull Mountain Quadrangle, Nye County, Nevada. U.S. Geological Survey. Geologic Quadrangle Map GQ-387.

Fernald, A.T., 1979. Map of the Tuff Aquitard (Lower Tuff Units) in Yucca Flat, Nevada Test Site. U.S. Geological Survey, USGS-474-262, 9p.

Gibbons, A.B., E.N. Hinrichs, W.R. Hansen and R.W. Lemke, 1963. Geology of the Rainier Mesa Quadrangle. U.S. Geological Survey, Geologic Quadrangle Map GQ-215.

Hinrichs, E.N., 1968. Geologic Map of the Camp Desert Rock Quadrangle, Nye County, Nevada. U.S. Geological Survey, Geologic Quadrangle Map GQ-726.

Hinrichs, E.N., R.D. Krushensky and S.J. Luft, 1967. Geologic Map of the Ammonia Tanks Quadrangle, Nye County, Nevada. U.S. Geological Survey, Geologic Quadrangle Map GQ-638.

Hinrichs, E.N. and E.J. McKay, 1965. Geologic Map of the Plutonium Valley Quadrangle, Nye and Lincoln Counties, Nevada. U.S. Geologic Survey, Geologic Quadrangle Map GQ-384.

Maldonado, F., 1985. Geologic Map of the Jackass Flats Area, Nye County, Nevada. U.S. Geological Survey, Miscellaneous Investigations Series Map I-1519. 
McKay, E.J. and K.A. Sargent, 1970. Geologic Map of the Lathrop Wells Quadrangle, Nye County, Nevada. U.S. Geological Survey, Geologic Quadrangle Map GQ-883.

McKay, E.J. and W.P. Williams, 1964. Geology of the Jackass Flats Quadrangle, Nye County, Nevada. U.S. Geological Survey, Geologic Quadrangle Map GQ-368.

McKeown, F.A., D.L. Healey and C.H. Miller, 1976. Geologic Map of the Yucca Lake Quadrangle, Nye County, Nevada. U.S. Geological Survey, Geologic Quadrangle Map GQ-1327.

Orkild, P.P., 1963. Geologic Map of the Tippipah Spring Quadrangle, Nye County, Nevada. U.S. Geological Survey, Geologic Quadrangle Map GQ-213.

Orkild, P.P., 1968. Geologic Map of the Mine Mountain Quadrangle, Nye County, Nevada. U.S. Geological Survey, Geologic Quadrangle Map GQ-746.

Orkild, P.P., K.A. Sargent and R.P. Snyder, 1969. Geologic Map of Pahute Mesa, Nevada Test Site and Vicinity, Nye County, Nevada. U.S. Geological Survey, Miscellaneous Geologic Investigations Map I-567.

Poole, F.G., 1965. Geologic Map of the Frenchman Flat Quadrangle, Nye, Lincoln, and Clark Counties, Nevada. U.S. Geological Survey, Geologic Quadrangle Map GQ-456.

Poole, F.G., D.P. Elston and W.J. Carr, 1965. Geologic Map of the Cane Spring Quadrangle, Nye County, Nevada. U.S. Geological Survey, Geologic Quadrangle Map GQ-455.

Rogers, C.L. and D.C. Noble, 1969. Geologic Map of the Oak Spring Butte Quadrangle, Nye County, Nevada. U.S. Geological Survey, Geologic Quadrangle Map GQ-822.

Sargent, K.A., S.J. Luft, A.B. Gibbons and D.L. Hoover, 1966. Geologic Map of the Quartet Dome Quadrangle, Nye County, Nevada. U.S. Geological Survey, Geologic Quadrangle Map GQ-496.

Sargent, K.A., E.J. McKay and B.C. Burchfiel, 1970. Geologic Map of the Striped Hills Quadrangle, Nye County, Nevada. U.S. Geologcal Survey, Geologic Quadrangle Map GQ-882.

Sargent, K.A. and J.H. Stewart, 1971. Geologic Map of the Specter Range NW Quadrangle, Nye County, Nevada. U.S. Geological Survey, Geologic Quadrangle Map GQ-884.

U.S. Geological Survey, 1984. A Summary of Geological Studies Through January 1, 1983, of a Potential High-Level Radioactive Waste Repository Site at Yucca Mountain, Southern Nye County, Nevada. U.S. Geological Survey Open-File Report 84-792, 103p. 


\section{DISTRIBUTION}

\section{U.S. Department of Energy}

Gylan Allen

Test Operations Division

Nevada Operations Office

U.S. Dept. of Energy

P.O. Box 98518

Las Vegas, NV 89193-8518

Doug Duncan

Hydrology Program Manager

Office of Environmental Restoration \& Waste

Management

Nevada Operations Office

U.S. Dept. of Energy

P.O. Box 98518

Las Vegas, NV 89193-8518

Don Elle, Director

Environment Protection Division

Nevada Operations Office

U.S. Dept. of Energy

P.O. Box 98518

Las Vegas, NV 89193-8518

Joseph N. Fiore, Acting Asst. Mgr.

Office of Environmental Restoration \& Waste

Management

Nevada Operations Office

U.S. Dept. of Energy

P.O. Box 98518

Las Vegas, NV 89193-8518

Joseph H. Kitchen

Technology and Program Management Division

Nevada Operations Office

U.S. Dept. of Energy

P.O. Box 98518

Las Vegas, NV 89193-8518

Steve Lawrence

Environmental Restoration Division

Nevada Operations Office

U.S. Dept. of Energy

P.O. Box 98518

Las Vegas, NV 89193-8518
John S. Ledbetter

Contracts Division

Nevada Operations Office

U.S. Dept. of Energy

P.O. Box 98518 , MS 505

Las Vegas, NV 89193-8518

Steve Leedom

Test Operations Division

Nevada Operations Office

U.S. Dept. of Energy

P.O. Box 98518

Las Vegas, NV 89193-8518

Steve Mellington, Director

Environmental Restoration Division

Nevada Operations Office

U.S. Dept. of Energy

P.O. Box 98518

Las Vegas, NV 89193-8518

Richard Pearl

Environmental Protection Division

Nevada Operations Office

U.S. Dept. of Energy

P.O. Box 98518

Las Vegas, NV 89193-8518

\section{U.S. Department of Defense}

David Bedsun

Defense Nuclear Agency

U.S. Department of Defense

P.O. Box 98539

Las Vegas, NV 89193-8539

\section{Lawrence Livermore National Laboratory}

Lee Davisson

Nuclear Chemistry Division

Lawrence Livermore National Laboratory

P.O. Box 808, MS L237

Livermore, CA 94550

Greg Nimz

Lawrence Livermore National Laboratory

P.O. Box 808, MS L233

Livermore, CA 94550 


\section{Los Alamos National Laboratory}

Joe Thompson

Los Alamos National Laboratory

INC-11, MS J514

P.O. Box 1663

Los Alamos, NM 87545

\section{U.S. Geological Survey}

Virginia Glanzman

U.S. Geological Survey

Box 2506, MS 913

Denver Federal Center

Denver, CO 80225

Randy Laczniak

U.S. Geological Survey

Water Resources Division

6770 S. Paradise Rd.

Las Vegas, NV 89119

Paul Orkild

U.S. Geological Survey

Box 2506, MS 913

Denver Federal Center

Denver, CO 80225

Doug Trudeau

U.S. Geological Survey

Water Resources Division 6770 S. Paradise Rd.

Las Vegas, NV 89119

\section{Desert Research Institute}

Roger Jacobson

Desert Research Institute

Water Resources Center

P.O. Box 19040

Las Vegas, NV 89132-0040

Marjory Jones

Desert Research Institute

Water Resources Center

P.O. Box 60220

Reno, NV 89506-0220
Dick French

Desert Research Institute

Water Resources Center

P.O. Box 19040

Las Vegas, NV 89132-0040

Reynolds Electrical \& Engineering Co.

Martha DeMarre

Chief, Document Research Section

Health Protection Dept.

Reynolds Electrical \& Engineering Co.

P.O. Box 98521

Las Vegas, NV 89193-8521

Brian Dozier

Reynolds Electrical \& Engineering Co.

2501 Wyandotte

Mercury, NV 89102

State of Nevada

Larry Franks

Nevada State Health Department

Radiological Health Section

620 Belrose Avenue

Las Vegas, NV 89158

\section{Libraries}

Annie Kelley

State Documents Department

Nevada State Library

Capitol Complex

Carson City, NV 89710

Archives

Getchell Library

University of Nevada, Reno

Beverly Carter

MacKay School of Mines Library

University of Nevada, Reno

Document Section, Library

University of Nevada, Las Vegas

4505 Maryland Parkway

Las Vegas, NV 89154

Southern Nevada Science Center

Water Resources Center, Library

P.O. Box 19040

Las Vegas, NV 89132-0040 
Stead Library

Desert Research Institute

Reno, Nevada

Technical Information Resource Center

Nevada Operations Office

U.S. Dept. of Energy

P.O. Box 98518

Las Vegas, NV 89193-8518

Water Resources Research Archives

University of California

Room 40, North Gate Hall

Berkeley, CA 94720

\section{International Technology Corp.}

Rick Waddell

Geotrans

c/o IT

4330 Valley View

Suite 112

MS-439

Las Vegas, NV 89103

Joe Yeasted

International Technology Corp.

4330 S. Valley View

Suite 114

Las Vegas, NV 89132-0040 